University of Michigan Law School

University of Michigan Law School Scholarship Repository

\title{
Alternatives to Civil Commitment of the Mentally III: Practical Guides and Constitutional Imperatives
}

David L. Chambers

University of Michigan Law School, dcham@umich.edu

Available at: https://repository.law.umich.edu/articles/99

Follow this and additional works at: https://repository.law.umich.edu/articles

Part of the Civil Rights and Discrimination Commons, Health Law and Policy Commons, Law and Psychology Commons, Legislation Commons, and the Medical Jurisprudence Commons

\section{Recommended Citation}

Chambers, David L. "Alternatives to Civil Commitment of the Mentally III: Practical Guides and Constitutional Imperatives." Mich. L. Rev. 70 (1972): 1107-200.

This Article is brought to you for free and open access by the Faculty Scholarship at University of Michigan Law School Scholarship Repository. It has been accepted for inclusion in Articles by an authorized administrator of University of Michigan Law School Scholarship Repository. For more information, please contact mlaw.repository@umich.edu. 


\section{ALTERNATIVES TO CIVIL COMLITMENT OF THE MENTALLY ILL: PRACTICAL GUIDES AND CONSTITUTIONAL IMPERATIVES}

David L. Chambers

Table of Contents

I. INTRODUCTION . . . . . . . . . . . . . . . 1108

II. The Variety and Effectiveness of the Alternatives to Hospitalization . . . . . . . . . . . . . 1112

B. The Range of Alternatives to Hospitalization . . . 1112

A. Goals of State Commitment Codes . . . . . . 1119

C. The Effectiveness of Alternatives to Hospitalization in Serving State Goals . . . . . . . . . . . 1121

III. The Legal Obligation To Search for Alternatives to Hospitalization . . . . . . . . . . . . . 1137

A. The Undetected Flexibility of Existing State Codes 1138

B. Constitutional Obligation . . . . . . . . . 1145

1. The Principle of the Least Restrictive Alternative in Constitutional Adjudication . . . . . . 1145

2. The Few Civil Commitment Cases on Point . . 1151

3. Civil Commitment Involves So Severe an Infringement of Fundamental Liberties That Alternatives Must Be Explored . . . . . . . 1155

IV. Ensuring That a Meaningful Search for Alternatrves Occurs . . . . . . . . . . . . . . . 1168

A. The Appropriate System To Ensure That Alternatives Are Examined . . . . . . . . . . . 1168

B. The Power of Committing Courts To Compel Alternative Facilities To Cooperate . . . . . . . 1177

C. The Appropriate Stage in Proceedings for Examining Alternatives . . . . . . . . . . . . . . 1178

V. GoIng BEYoND . . . . . . . . . . . . . . . 1182

A. Reaching the Voluntary Patient . . . . . . 1182

B. Requiring the Use of Alternatives Even When They Are Less Effective Than Hospitalization . . . . 1184

C. Forcing the State To Create Less Restrictive Alternatives . . . . . . . . . . . . . . 1189 


\title{
ALTERNATIVES TO CIVIL COMMITMENT OF THE MENTALLY ILL: PRACTICAL GUIDES AND CONSTITUTIONAL IMPERATIVES
}

\author{
David L. Chambers*
}

\section{INTRODUGTION}

$I^{n}$ N 1930, Ford sold Fords only in black and states offered treatment for mental illness only in public mental hospitals. Today, new views of mental health care and mental health problems have begotten a galaxy of new treatment settings. Few cities can boast community-based programs sufficient to meet their needs, but almost all cities of any size rely increasingly on outpatient programs. The large public mental hospitals still stand, of course. Indeed, every year more people enter public hospitals than entered the year before. Over 400,000 Americans were admitted as inpatients to state and county mental hospitals last year. ${ }^{1}$ Partly because of the new outpatient services, patient stays tend to be shorter than they once were, but, short or long, a large portion of the 400,000 underwent anguish, terror, and embarrassment in the sudden separation from home and family and the sudden loss of privacy and self that accompanies confinement on a ward with fifty or a hundred strangers. Precisely what portion of these 400,000 were involuntarily committed is not known, but it is probably more than fifty per cent. ${ }^{2}$ What portion of the 400,000 could have been treated and protected as well or better outside the hospital is also unknown, but, as we shall see, the percentage also seems likely to have been high.

The most forthright suggestion for ending the undue reliance

* Associate Professor of Law, University of Michigan. B.A. 1962, Princeton University; LL.B. 1965, Harvard University.-Ed.

1. In the year ending June 30,1971 , there were 414,926 new admissions to state and county mental hospitals, a $51 / 2 \%$ increase over 1970 and a continuation of a trend of increasing admissions to these hospitals during the preceding 20 years. Sce H. Bethel \& R. Redick, Provisional Patient Movement and Administrative Data, State and County Mental Hospital Inpatient Services, July 1, 1970-June 30, 1971, Statistical Note 60, Survey and Reports Section, National Institute of Mental Health, at 2 (1972). On the other hand, during this period there has also been a steady decline in the total portion of mental health care treatment episodes in this country conducted in such hospitals and a steady rise in the portion conducted on an outpatient basis. See notes $42-43$ infra and accompanying text.

2. A study completed in 1968 for the American Bar Foundation found that in $\mathbf{4 5}$ states, accounting for $88 \%$ of hospital admissions, only $40 \%$ of admissions were voluntary. The Mentally Disabled and the LAw 17 (S. Brakel \& $R$. Rock rev. ed. 1971) [hereinafter S. Brakel \& R. Rock]. See also R. Rock, M. Jacodson \& R. Janopaul, Hospitalization and Discharge of the Mentally ILL 4143 (1968) (another study sponsored by the American Bar Foundation).

[1108] 
on compulsory hospitalization has been to forbid it altogether. Two of the functions states seek to serve through hospitalization-protecting the individual from himself and providing him care and treatment-are commendable as bases for offering help but questionable as bases for forcing help on someone who does not want it. A third function-protecting the community from dangers posed by the ill person-does justify compulsory intervention for certain kinds of dangers, but such grave difficulties are posed in accurately predicting dangerousness that most people held will in fact prove harmless. Moreover, only the most tenuous justification exists for retaining two forms of commitment, one labeled civil and resting on a concept of "mental illness" and another labeled criminal and resting on an equally shaky concept of "responsibility." To date, however, courts have proved unwilling to curtail civil commitment, and in truth courts are no more likely to force an end to compulsory hospitalization than they are to force an end to prisons.

This article does seek to encourage the movement away from inpatient hospitalization but more gently-through approaches and doctrines that seek to allay rather than kindle the anxieties of the public about mental illness. It is my belief (backed, I hope to demonstrate, by a growing body of research) that even if we concede that governments may hospitalize an ill person to protect him from himself, or to protect others from him, or simply to treat or care for him, these goals can generally be better served by keeping him in the community than by removing him.

This perception that care in a public hospital is less satisfactory than outpatient care for serving the state's own goals provides a basis for statutory and constitutional arguments for curtailing the current level of reliance on forced hospitalization. State commitment codes do not compel the hospitalization of all mentally ill persons and most could sensibly be construed to permit hospitalization only when the state's purposes are best served by doing so. Similarly, the United States Supreme Court and other courts, when confronted by regulations that encroach on important constitutionally protected freedoms or interests (for example, free expression, the flow of interstate commerce, or the right to travel), have often insisted as a minimum condition for sustaining the regulations that the government serve its purposes by employing the means least restrictive of the constitutionally protected interest. The rights most severely curtailed by civil commitment-the rights of association and travel and the more elusive, less well established, but no less respectable, constitutionally based concern for freedom from physical confinement-should sim- 
ilarly be held to require the use of less restrictive alternatives to hospitalization whenever the state's interests can be served. Indeed, a few lower courts have already indicated support for this position. ${ }^{3}$

Even if appellate courts do hold that community alternatives must be preferred over hospitalization whenever state goals can be served, obstacles will still remain to reliance by judges on community treatment. Even the most willing judge will be unable to assure that an adequate inquiry for alternatives occurs without the aid of professional advice currently unavailable in most states. Probation officers provide advice on community placement to judges in criminal and juvenile courts. Functionally similar advisers need to be available to commitment judges. If necessary, the Constitution can supply the force to compel states to establish some sort of system to ensure that an adequate inquiry into alternatives occurs.

My development of these and other points fills a wastebasket full of pages. In partial defense, I can only point out that, in terms of procedural and substantive rights, the mentally ill stand today where the criminal defendant stood in 1935 and the juvenile offender stood in 1960. Indeed, so far as I can find, the Supreme Court has decided only three cases in its entire history dealing with any aspect of civil commitment and two of these, ${ }^{4}$ and perhaps even the third, 5 can be seen as reflecting primarily the Court's concern for persons convicted of crimes. The Court has itself recently expressed surprise at the paucity of cases. ${ }^{6}$ Thus, if the Court did decide to hear a case

3. Covington v. Harris, 419 F.2d 617 (D.C. Cir. 1969); Dixon v. Attorney General, 325 F. Supp. 966, 971 (M.D. Pa. 1971). See text accompanying notes 198-205 infra.

4. Baxstrom v. Herold, 383 U.S. 107 (1966) (holding unconstitutional under the equal protection clause New York's practice of transferring to mental hospitals convicted criminals completing sentences without providing them the procedural protcctions given to others facing civil commitment); Lynch v. Overholser, 369 U.S. 705 (1962) (holding, by statutory construction, that the District of Columbia statute providing for automatic hospitalization of those found not guilty by reason of insanity cannot be applied to those who have not voluntarily raised the insanity defense). A third case, dealing with the constitutionality of Maryland's procedure for civilly committing repeated criminal offenders, "defective delinquents," has been argued before the Supreme Court, 40 U.S.L.W. 3477 (U.S. April 4, 1972), and is presently awaiting decision. Tippet v. Maryland, 436 F.2d 1153 (4th Gir.), cert. granted stbb nom. Muriel v. Baltimore City Criminal Court, 404 U.S. 999 (1971). Cf. Humphrey v. Cady, 40 U.S.L.W. 4324 (U.S. March 22, 1972); Specht v. Patterson, 386 U.S. 605 (1967) (each dealing with special provisions for extended confinement beyond normal sentences for sex offenders and involving procedures partly resembling civil commitment).

5. Minnesota ex rel. Pearson v. Probate Court, 309 U.S. 270 (1940) (upholding statute permitting involuntary commitment of sex psychopaths, the basis for whose commitment could, and usually does, rest on prior convictions for sex offenses).

6. In Jackson v. Indiana, 40 U.S.L.W. 4615, (U.S. June 7, 1972), the Court held un. constitutional open-ended confinement of a person found incompetent to stand trial. Justice Blackmun, speaking for a unanimous Court, said, "Considering the number of persons affected [by commitment statutes] it is perhaps remarkable that the substantive 
dealing solely with civil commitment and did require state courts to explore alternatives before committing people to hospitals, ${ }^{7}$ such a decision might well be "one of those bridge decisions that open up new terrain by connecting it with familiar ground."8 Traveling the unfamiliar terrain of civil commitment, the Justices would find open-ended commitments without counsel years after Gideon and Gault. They would stumble through acres of hazy, ill-defined commitment standards like "dangerous to self or others" or "in need of care and treatment" and learn of commitment hearings unattended by the doctors seeking the allegedly ill person's commitment (or even by the allegedly ill person himself) and so cursory that dozens can be conducted in a single morning. Contemplating a terrain so craggy, the Court might understandably wish to burn its bridge before crossing it.

If a beginning be made, however, few better starting points exist than the issue of alternatives to commitment. The principle of the least restrictive alternative ${ }^{9}$ is a most limited and modest incursion on a state's interests. It does not prevent the state from achieving any of the objectives it seeks through commitment, but merely asks courts to ensure that the state imposes no greater constriction of freedom than necessary to serve the objectives. Equally important, the recognition of the principle in this context might help lawyers and judges perceive the mentally ill as human beings with problems often possible of solution in the outside world. To demonstrate that the schizophrenic with the frightened eyes and frightening beliefs can survive at home may humanize lawyers, judges, and the public generally in their dealings with the mentally ill over a broad range of other issues. ${ }^{10}$

constitutional limits on this power have not been more frequently litigated." 40 U.S.L.W. at 4622 .

7. The Supreme Court has dismissed for want of a substantial federal question one case raising the issue of the constitutional obligation of committing courts to employ less restrictive alternatives. State v. Sanchez, 80 N.M. 438, 457 P.2d 370 (1968), appeal dismissed, 396 U.S. 276 (1969). For a discussion of the case and why it provides little indication of the Court's probable attitude toward the issue if fully argued, see text accompanying notes 150-55 and 189-97 infra.

8. P. Freund, ON Law and Justice 4 (1968).

9. What I refer to as the "principle of the least restrictive alternative" is often labelled by others as the principle of "Iess drastic means" (see, e.g., Note, Less Drastic Means and the First Amendment, 78 YALE L.J. 464 (1968)) or as the principle of "reasonable alternatives" (see, e.g., Wormuth \& Mirken, The Doctrine of Reasonable Alternatives, 9 Utaf L. REv. 254 (1964)). The Supreme Court, to its credit, has never used a single catchy phrase.

10. There is evidence that public attitudes toward the mentally ill are gradually improving. See G. Crocetti, H. Spiro \& I. Siassi, Are the Ranks Closed? Attitudinal Social Distance and Mental Illness, 127 AM. J. Psxchiatry 112 (1971) (summarizing 


\section{The Variety and Effectiveness of the Alternatives to Hospitalization}

Since the inspiration to require an exploration of alternatives to hospitalization is likely to come to courts more from a recognition of the potential the alternatives offer for serving the state's needs than from the overpowering persuasiveness of the legal arguments that will be advanced, let us begin by looking at the range and effectiveness of these alternatives. A great deal of medical and social science literature exists. Perhaps the discussion that follows can help lead lawyers to it.

\section{A. The Range of Alternatives to Hospitalization}

One hundred twenty years ago, many doctors prescribed hospitalization as the only acceptable form of treatment for the mentally ill. ${ }^{11}$ In 1863, the celebrated Dr. Isaac Ray asserted unequivocally in support of hospitalization that "[i]t is now a well-settled principle, that ... the surroundings of the patient should be entirely changed, so that he shall see no face nor other object familiar to him in the previous stage of his disease ...."12 Visits, even correspondence, with family were to be discouraged. ${ }^{13}$ The doctors would restore order to the mind by housing the patients in an ordered environment-a hospital with long and straight corridors, firmly set schedules, and consistent, warmly administered discipline. Acting on this principle, states erected hospitals in rural settings far from the communities they served. ${ }^{14}$

During the latter part of the nineteenth century, the hospitals became vastly overcrowded, re-creating the very disorder that their founders had sought to avoid.15 Most patients suffered from chronic

research on public attitudes toward the mentally ill, much of it unencouraging, but setting forth a recent study of attitudes of workers at an auto plant in Baltimore that found high levels of optimism about the potential for treatment of the ill and high levels of willingness to work with or live with an ex-mental patient).

11. For a thorough account of the enthusiasm of the medical profession for hospitalization in the mid-nineteenth century, see D. Rothman, The Discovery of the Asylum 130-54 (1971). See also E. Bond, Dr. KIRkBride and His Mental Hospital (1947).

12. I. Rax, Mental Hygiene 323 (1863). Dr. Ray was one of the founders of what is now known as the American Psychiatric Association and an administrator of both public and private hospitals.

I3. Id. at $324-25$.

14. D. Rothman, stipra note 11, at 141-42.

15. D. Rothman, supra note 11, 265-87 (1971); Michigan Dept. of Mental Health, The Development and Growth of Michigan's Mental Health Program: A History of 125 Years of Transition and Progress 7-12 (1962). 
illnesses and remained hospitalized until death. Today, seventy-five years later, many of the same hospitals remain in use and the median length of stay for older patients in many hospitals still exceeds ten years. ${ }^{16}$ Despite recent ardent and praiseworthy efforts to reshape these hospitals into places for treatment, success has been limited. Few experts today recommend hospitalization, particularly in the large public mental hospital, as the preferred setting for treatment to occur. Those who defend hospitalization ${ }^{17}$ do so in terms that exclude most public mental hospitals, which generally remain understaffed, overcrowded, and distant. ${ }^{18}$ The very ground on which hospitalization was praised in the past-that it separated the patient from the surroundings he found troublesome-emerged as a principal target for attack. Separation, it is now believed, impedes reintegration into community life; and the isolation of hospitalization, coupled with other aspects of institutionalization, breeds further withdrawal and deterioration. ${ }^{19}$

Most writers on mental health today believe that mentally ill persons generally respond best to care provided in the setting in which the patients' problems have arisen. ${ }^{20}$ "Community mental health care" or "community psychiatry,"21 the loosely used labels for the new approach, is characterized at its best by flexibility, pragmatism, and accessibility. ${ }^{22}$ Drawing on many more disciplines than

16. R. Redick, Length of Stay-State and County Mental Hospitals Selected States, Statistical Note 20, Survey and Reports Section, National Institute of Mental Health, Tables 1-2, at $4-5$ (1970).

The median length of stay for patients residing in state and county mental hospitals runs between 4.5 to 8.6 years for all age groups for the few states which publish comparable data (California, Connecticut, Delaware, District of Columbia, Oregon, and West Virginia). Id. at 2. The median length of stay increases with each older age group through age 64 .

17. On the potential for treatment in a well-staffed hospital, see Kubie, The Future of the Private Psychiatric Hospital, in Crosscurrents in Psychiatry and PsychoanalYsis 179, 184-86 (R. Gibson ed. 1967).

18. A study sponsored in part by the American Bar Foundation of twenty-two representative state-operated mental hospitals found that "[a]11 but a few of the institutions studied operate at 20 to 50 per cent above their official bed capacity. Further, the generally small size of medical staffs and the relatively small number of trained psychiatrists in public hospital practice precludes care of all but a few patients at anything above a bare minimum." $R$. Rock, M. JACOBsON \& $R$. JaNOPAUL, supta note 2 , at $69-70$.

19. See notes 81-90 infra and accompanying text.

20. See Wedge, Changing Perceptions of Mental Health, 48 MEnTal Hygiene 22 (1964) and articles and books Wedge cites.

21. For a discussion of the basic terms and the uses made of them, see Sabshin, Theoretical Models in Community and Social Psychiatry, in CoMmunity Psychiatry 15-30 (L. Roberts, S. Halleck \& M. Loeb ed. 1966). See also Zuithoff, Community Psychiatry and Social Action-A Survey, 126 Am. J. Psychiatry 162 (1970).

22. See, e.g., Folta \& Schatzman, Trends in Public Urban Psychiatry in the United 
psychiatry and many more settings than inpatient care, it seekş to provide a diversity of approaches equal to the diversity of human misfortune. It seeks to deal not simply with misfortunes labeled as illnesses but also with problems of housing, employment, and public assistance benefits; not simply with the treatment of the person labeled as ill but also with the family unit as a whole.

The development of alternatives to inpatient hospitalization began in this country in the early part of this century ${ }^{23}$ but did not spread rapidly until after World War II. ${ }^{24}$ Imaginative mental health programs developed by the military during the War and by the British and the Dutch before and after the War ${ }^{25}$ inspired much of the recent development. The English and Dutch, through programs that successfully treated ill persons on an outpatient basis, reduced sharply the number of patients residing in their hospitals. ${ }^{26}$ (In fact, Britain's Department of Health and Social Security has recently announced a plan to close all of the nation's 116 remaining mental hospitals over the next fifty years. $)^{27}$

In this country, New York in 1954 enacted the first community mental health services legislation to encourage the urban-based outpatient clinics. ${ }^{28}$ Thirteen other states enacted similar legislation, with limited funding, over the next ten years. ${ }^{20}$ Congress has since provided much of the impetus - but too small a share of the fundsfor greatly expanded community mental health programs and facilities in the United States. In 1955, it established a commission to study the state of mental health programs and facilities in the United States. ${ }^{30}$ Six years later, the commission issued an influential

States, 16 Social Problems 60, 67-71 (1968); Freedman, Historical and Political Roots of the Community Mental Health Centers Act, 37 AM. J. ORTHopsychiatrx 487 (1967).

23. See Ewalt \& Ewalt, History of the Community Psychiatry Movement, 126 AM. J. PsychiatrX 43 (1969); Rossi, Some Pre-World War II Antecedents of Communily Mental Health Theory and Practice, in Perspectives IN CoMmunity MENTaL Healti 9 (A. Bindman \& A. Spiegel ed. 1969).

24. See Freedman, supra note 22.

25. See Margolis \& Bonstedt, What Is Community Psychiatry?, 31 DisEAsEs of THE NeRvous System 251 (1970); Yolles, Mental Health's Homoeostatic State: A New Territory, 7 INTL. J. Psychiatry 327, 330 (1970).

26. See Clark, The Emergence of Priorities in Psychiatry, 125 AM. J. PsYchistry 1218 (1969) (describing the British effort); Querido, The Shaping of Community Mental Health Gare, 7 INTL. J. Psxchiatry 300 (1970) (describing the Dutch effort).

27. Time, Jan. 24, 1972, at 41 .

28. See S. BRAKEL \& R. Rock, supra note 2, at 9.

29. $I d$.

30. The Mental Health Study Act of 1955, ch. 417, \& 3, 69 Stat. 382, authorized the appropriation of 1.25 million dollars that was used to establish the Joint Commission on Mental Illness and Health. 
report urging reduced emphasis on hospitalization and the rapid development of outpatient clinics and services. ${ }^{31}$

This report apparently helped persuade President Kennedy to propose broad new federal legislation. In a frequently quoted message to Congress, the President declared that " $[t]$ he time has come for a bold new approach. . . . When carried out, reliance on the cold mercy of custodial isolation will be supplanted by the open warmth of community concern and capability." ${ }^{32}$ The President set as a goal-which appears in fact largely to have been met $^{33}$-a reduction by one half in the nation's mental hospital resident population by the mid-1970's.

Responding to the President's call, Congress in 1963 enacted the Community Mental Health Centers Act, authorizing substantial sums of federal matching monies for community-based treatment facilities. $^{34}$ Between 1963 and 1968, forty-three states enacted enabling legislation to qualify them for funds under the Act. ${ }^{35} \mathrm{By}$ 1969, 350 community mental health centers were participating under the Act. ${ }^{38}$ Under federal regulations, each federally supported center must provide short-term inpatient, outpatient, part-time inpatient, emergency and diagnostic services. ${ }^{37}$ Although centers have not opened nearly as quickly or provided as many services as had been hoped, ${ }^{38}$ they have treated hundreds of thousands of persons, ${ }^{39}$ many

31. JoInt Commission on Mentar Illness and Health, Action for Mental Health (1961). See especially the summary of recommendations at vii-xxiv.

32. Message from the President of the United States Relative to Mental health and Mental Retardation, H.R. Doc. No. 58, 88th Cong., Ist Sess. 2-3 (1963).

33. At least as measured from its highest point-at the end of June 1955 when resident population in public hospitals was 558,900 -population is now down nearly by half. It is also down nearly by half from its level at the time the President gave his speech (504,600 in June 1963). At the end of June 1971, population had declined to 308,000 and was declining at a rate likely to yield a total patient population well below 300,000 by mid-1972. (See note 69 infra for source and for an explanation of the reasons for the over-all decline in patient population.)

34. Pub. L. No. 88-164, tit. II, 77 Stat. 290, as amended, 42 U.S.C. $\$ \S 2681-87$ (1970). In 1968, Congress established a new program to underwrite community treatment for alcoholics and narcotics addicts (Alcoholic and Narcotic Addict Rehabilitation Amendments of 1968, Pub. L. No. 90-574, tit. III, $\S \S 301-03,82$ Stat. 1006, as amended, 42 U.S.C. $\$ \S 2688$ e to $2688 \mathrm{j}(1970)$ ) and, in 1970 , authorized extra funding for mental health programs in low income areas (Act of March 13, 1970, Pub. L. No. 91-211, tit. III, § 302, 84 Stat. 58 (codified at 42 U.S.C. § 2688f(b) (1970)).

35. See S. BRAREL \& R. Rock, supra note 2 , at 10.

36. Id.

37. 42 C.F.R. § 54.212(a) (1971).

38. To those who have surveyed the community health movement, the state of community mental health today simultaneously encourages and disappoints. Though in absolute numbers the scope of community-based programs is vastly greater than it was a decade ago, it remains far short of the stated goals of Congress in 1963. S. Brakel \&: R. Rock, supra note 2 , at 10 . Two thousand centers by 1979 was the original goal; today 
of whom would probably otherwise have been hospitalized. During this past decade, there has also: been a comparable and even vaster expansion of outpatient mental health services through general hospitals and other clinics not federally funded, ${ }^{10}$ as well as a similarly vast expansion of short-term inpatient care in psychiatric wards within general hospitals. ${ }^{41}$ Thus, in the thirteen years from 1955 to 1968, largely because of the expanded services and their accessibility, the number of persons annually receiving some form of mental health care in this country more than doubled. ${ }^{42}$ Outpatient services and community mental health centers that in 1955 had accounted for less than one quarter of patient-care episodes accounted by 1968 for more than one half. ${ }^{43}$

No less important than the development of community-based facilities has been the development and diffusion of new tranquiliz-

the date for achievement has been pushed back to 1980. Id. Even as to centers that have opened, many are unable to offer the full range of services the regulations require. Id. at 11. Congressional authorizations and appropriations have been too low to meet the aims. As one critic has pointed out, total funds appropriated under the Community Mental Health Centers Act from 1964 to 1968 have been no more than the funds required to operate the New York State Department of Mental Hygiene for five months. See R. Glasscote, J. Sussex, E. Cunming \& L. Smrth, The Community Mental Healti CENTER: AN INTERIM APPRAISAL 6 (1969). The states have in short remained saddled with the vast bulk of costs. State mental health expenditures for the year ending Junc 30, 1970, exceeded two billion dollars. F. Bethel \& R. Redick, supra note 1, Table 3, at 7 .

39. In 1969 , at federally funded community mental health centers 312,000 persons received outpatient services, 76,000 received inpatient services, and 24,000 received partial hospitalization services. C. Taube, Distribution of Patient Care Episodes in Mental Health Facilities, 1969, Statistical Note 58, Survey and Reports Section, National Institute of Mental Health, Table A, at 4 (1972) [hereinafter Statistical Note 58].

40. Nonfederally funded outpatient clinics in general hospitals or elsewhere handled 379,000 cases in 1955 and $1,507,000$ cases in 1968, a nearly fourfold increase. C. Taube, Changes in the Distribution of Patient Care Episodes-1955-68-By Type of Facility, Statistical Note 23, Survey and Reports Section, National Institute of Mental Hicalth 3 (1970) [hereinafter Statistical Note 23].

41. "Today [general hospitals] admit more patients for the first episode of mental illness than do all other mental hospitals combined . . . ." Ewalt \& Ewalt, supra note 23, at 46. Between 1967 and 1969, the number of beds in psychiatric units of general hospitals increased by $21 \%$. C. Taube, General Hospital Psychiatric Inpatient Units, 1969-1970, Statistical Note 44, Survey and Reports Section, National Institute of Mental Health, Table B, at 3 (1971).

42. From 1.7 million "patient-care" episodes (i.e., sum of residents at beginning of year or on active rolls of clinics plus admissions during the year) in all facilitics in 1955 to 3.65 million episodes in 1969. Statistical Note 58, supra note 39, at 2; Statistical Note 23, supra note 40, at 2.

43. Statistical Note 23 , supra note 40 , at 2 . The rate of inpatient hospitalization at state and county mental hospitals declined from 505 per 100,000 population to 384 per 100,000. Total patient-care episodes in such hospitals declined slightly from 819,000 in 1955 to 767,000 in 1968 . Statistical Note 58 , supra note 39 , Table A, at 4 . Statistical Note 23, supra, at 3. 
ing medications, such as thorazine. ${ }^{44}$ Since the mid-1950's, reliance on these new medicines has become nearly universal in the treatment of psychotic patients both inside and outside hospitals. These medicines have profoundly altered the atmosphere within the public mental hospitals. More important for our concerns, they have permitted large numbers of persons who might previously have been hospitalized to survive in the community. ${ }^{45}$ As stated in one important study of the community mental health movement, " $t]$ he drug revolution has probably had a more profound effect on the mental hospital as an institution and as part of a community care program than all the other changes combined." 46

The range of community facilities and programs is suggested in the sketch of the recent developments above, but a brief list of the alternatives from least to most restrictive of freedom may be instructive. We will take a closer look at the effectiveness of these alternatives in a later subsection. ${ }^{47}$

The least restrictive alternative of all, of course, is no treatment whatever. Given evidence of spontaneous remission of illness, ${ }^{48}$ a judge might find that he could serve the goals of the state's commitment statute as well or better by forbearing altogether from ordering any treatment for some ill patients or by seeking to make available to the patient services that fall outside what people generally consider the bounds of mental health care-aid in finding better housing, working out social security problems, or obtaining new false teeth. After all, recent studies have found that millions of people who suffer from what psychiatrists would label as serious mental illnesses survive in the community without governmental intervention. ${ }^{49}$ If some mental-health treatment appears necessary-

44. See Drug and Social Therapy in Chronic Schizophrenia 44-54 (M. Greenblatt, M. Solomon, A. Evans \& G. Brooks ed. 1965).

45. See Englehardt, Freedman, Glick, Hankoff, Mann, \& Margolis, Prevention of Psychiatric Hospitalization with Use of Psychopharmacological Agents, 173 J. A.M.A. 147 (1960). See also M. Greenblats, R. Moore, R. Albert \& M. Solomon, The Prevention of Hospitalization: Treatment Without Admission for Psychlatric Patients (1963).

46. B. Pasamanick, F. Scarpitti \& S. Dinitz, Schizophrenics in the Community 17 (1967).

47. See pt. II. C. infra.

48. See, e.g., Eysenck, The Effects of Psychotherapy, 1 INTL. J. Psychotherapy 97, 126 (Jan. 1965).

49. See L. Srole, T. Langner, S. Michael, M. Ofler \& T. Rennie, Mental Health In the Metropolis: The Mitown MaNhatTan StUdy 138 (1962) (random sampling in a densely populated area of New York City revealed that nearly a quarter of those sampled were or had been markedly impaired in their ability to function by reason of 
and it will be a rare judge who will feel comfortable in releasing altogether a person he believes seriously ill-a range of services may exist that permit a person to continue to live satisfactorily at home. Psychiatric or psychological counseling of the individual or the family unit or medication obtained through regular visits to an outpatient clinic may be sufficient. If the person is living alone, a visiting nurse or other home services may be adequate. ${ }^{50}$

For those who require closer supervision, a variety of facilities may exist that do not curtail freedom as drastically as commitment to a state hospital. Day-hospital care, under which a person stays at a clinic during the day but returns home at night, and its converse, night-hospital care, are promising and, by now, standard components of federally funded community mental health centers.51 The day hospital can serve, for example, elderly persons who live with their families but need help during the day when family members work; the night hospital can accommodate persons able to work in the community but unable to hold themselves together when alone at night. ${ }^{52}$ The aged and others may be placed in foster homes or halfway homes that provide full-time residence but are located in the community and generally permit the resident to come and go to the extent he is physically able. ${ }^{63}$ And even hospitalization itself need not entail a single degree of restriction. Inpatient care at a clinic or at a general hospital may permit the patient to remain close to his family and may inflict less damage to the patient's self-respect than confinement in a distant state hospital. If commitment to a state hospital is necessary, a short-term order, which many state codes permit, ${ }^{54}$

mental illness); Pasamanick, Roberts, Lenkau \& Krueger, A Survey of Mental Disease in an Urban Population, 47 AM. J. PUB. Health 923 (1957) (study of randomly selected households in Baltimore found $0.43 \%$ of the Baltimore population so seriously ill at the time of the study as to be considered "psychotic").

50. See J. Shapiro, Communities of the Alone (1971) (a heartening account of social workers providing services to residents of a single occupancy building, many of the occupants suffering from alcoholism).

51. See text accompanying note 37 supra.

52. For a succinct description of the sorts of patients best served by day hospitals and night hospitals, see Moll, The Day and Night Treatment Center, in THE Psycuratric UNIT IN A General Hospital 136-54 (M. Kaufman ed. 1965).

Although the number of day-care and night-care programs increased $300 \%$ between 1963 and 1967, relatively few patients participated. Of all admissions to mental health facilities in 1967, only 1\%were to these programs. C. Taube, Mental Health Day/Night Treatment Programs-1967, Statistical Note 6, Survey and Reports Section, National Institute of Mental Health, at 2 (1969).

53. See the study by R. Grasscote, J. Gudeman \& J. Elpers, Halfway Houses for THE MENTALly Ill (1971). See also a highly critical appraisal of the current state of nursing homes, G. Townsend, Old AGE-The LAST SEgREgation (1971).

54. S. BRAKEL \& R. Rock, supra note 2 , Table 1.1 , at $15-16$, and at 45.49 . 
is less restrictive of freedom (in a different but equally meaningful sense) than indefinite commitment.

\section{B. Goals of State Commitment Codes}

In the preceding section, I have suggested various "alternatives" to hospitalization without acknowledging that none of them can properly be labeled an alternative to hospitalization for purposes of this article except by serving one or more of the functions state legislatures have prescribed for their commitment codes. What are those functions? Speaking broadly, states expect hospitalization to protect the patient from himself, protect the public from the patient, and treat the patient for his illness. Unfortunately the states have articulated these purposes through statutory language ${ }^{55}$ murkier than the riddles of the witches of Macbeth.

Commitment statutes often authorize or require judges to commit persons who are "dangerous to others," without any legislative guidance on the sorts of conduct to consider "dangerous" or the degree of likelihood that must be shown of the conduct occurring. They also frequently authorize the commitment of those who are "dangerous to themselves," without statutory hint, beyond the obvious cases of imminent suicide or self-mutilation, of what sorts of more attenuated dangers to self are to be prevented. All of us human beings may, after all, be thought somewhat dangerous to ourselves in the sense that we take risks we would be wiser to avoid. A further common statutory authorization to commit ill persons who are "in need of care or treatment" similarly obscures more than it reveals, for the concept of treatment may incorporate many divergent notions: interrupting the disease process (by, for example, separating the alcoholic from alcohol), helping a patient acquire skills for living, helping him to modify unacceptable behavior, helping him develop an understanding of his problems, or even "curing" the disease.

These three functions of commitment, however crudely conveyed, are at least frequently stated. A fourth function, which may be viewed as an extension of the function of protecting the community, is one that legislatures would be embarrassed to express in statutory language and state courts unwilling to acknowledge: commitment serves

55. For the best compilation and review of commitment codes and their various formulations, see S. Brakel \& R. Rock, supra note 2, at 36-37. For excellent discussions of the difficulties posed by the statutory standards, see Livermore, Malmquist \& Meehl, On the Justifications for Civil Commitment, 117 U. PA. L. REv. 75 (1968); Note, Civil Commitment of the Mentally Ill: Theories and Procedures; 79 HARV. L. REv. 1288 (1966). 
to remove from sight those who make us feel uncomfortable. ${ }^{50}$ An ill person may pose no physical threat to our person or property yet unsettle us when we encounter him. Even if silent and withdrawn, he may cause us to worry about our own stability and create anxieties about our own sanity. For members of his family, the impact of his presence can be even more unsettling. ${ }^{57}$ One study of commitments found, for example, that bizarre behavior, rather than dangerous behavior or "inadequate role-playing," was most likely to lead to the rehospitalization of former mental-hospital patients. ${ }^{.8}$

Several implications flow from the multiple, ill-defined purposes that commitment may be intended to serve. First, to the extent that there are disputes about the functions of commitment, the principle of the least restrictive alternative, if accepted by courts, would offer no aid in their resolution. A committing judge would have to decide first what functions his code requires him to serve and what limits, if any, the state or federal constitution places on his power to commit in order to serve those functions. Only then could he turn to an inquiry into the adequacy of alternatives to serve the functions.

Second, in any given case, he would have to recognize that several different functions might be served by assuming control over an ill person. Most commonly, as we have seen, there will be a complex of functions relating to the protection of the ill person and the public and another complex of functions relating to treatment. In a particular case, for example, a judge might wish to find a disposition that protects the ill person from his propensity to wander and become lost and at the same time helps treat his condition so that it is less likely to recur. The judge will frequently find in practice that the two goals conflict-that any setting (such as hospitalization) that ensures protection will, by its isolation, impede efforts to treat, and that every setting that maximizes opportunities to treat poses risks for the protection of the patient or the public. Thus, the

56. There should be serious doubts about the constitutionality of locking someone up for merely being sick and unsettling. Cf. Coates v. City of Cincinnati, 402 U.S. 611 (1971) (Ohio statute prohibiting "annoying" assembly by three or more people on sidewalk held unconstitutionally vague and violative of rights of free assembly and association).

57. See text accompanying note 113 infra.

58. See Smith, Pumphrey \& Hall, The "Last Straw": The Decisive Incidents Resulting in the Request for Hospitalization in 100 Schizophrenic Patients, 120 AM. J. PsYchIATRY 228 (1963) (commitment of thirty-eight of one hundred closely studied was precipitated by socially unacceptable behavior, such as walking nude in a public park and eating raw chicken). See also H. Freeman \& O. Smamons, The Mental Patient COMES HOME 197 (1963). 
judge must decide the relative importance of the differing functions he wishes to serve. He may have to choose not the alternative that best serves all goals but the one that provides the optimum balance among competing goals. Only after he has made such judgments about goals can he make sensible judgments about the comparative effectiveness of alternatives. ${ }^{58}$

\section{G. The Effectiveness of Alternatives to Hospitalization in Serving State Goals}

Every year more studies report on the effectiveness of community mental health programs. Other studies add to the already impressive body of literature on the impact and efficacy of hospitalization. Though social scientists have been understandably halting in their efforts to develop acceptable measurements of success in community mental health ${ }^{60}$ and though controlled research into the compara-

59. The dangers of failing to examine the goals of hospitalization are illustrated by the first decision of an American court requiring an examination of alternatives. In Lake v. Cameron, 364 F.2d 657 (1966), the Court of Appeals for the District of Columbia Circuit remanded to the committing court the case of Ms. Catherine Lake, a woman of sixty-one who was suffering brain damage associated with senility, for a consideration of alternatives to hospitalization. See further discussion at text accompanying notes 143-48 infra. On remand, the district court surveyed a broad range of alternatives but did so with its compass fixed to a single point-protecting Ms. Lake from her propensity to wander and to become confused and subject to a variety of perils. Lake v. Cameron, 267 F. Supp. 155 (D.D.C. 1967). The court correctly concluded that incarcerating Ms. Lake provided the maximum insurance against her wandering. "Constant supervision is required," the court believed, "for the safety of the patient." $267 \mathrm{~F}$. Supp. at 158 .

The judge seemed to have been expressing genuine concern for Ms. Lake, but it was the concern that might be expressed for preserving an object-the corpus of a trust or the remains of the last passenger pigeon. Little concern was expressed for how the object liked the way she was being preserved. Moreover, supervision and protection were not the only goals of the District's legislation; treatment was an equal, if not more important, goal. D.C. CoDE \$ 21-562 (1967) provides that any person committed to a hospital "shall ... be entitled to mental and phychiatric care and treatment." No form of therapy or elixir of youth could, of course, have repaired Ms. Lake's brain damage, but no inquiry was made about whether it would have been possible for Ms. Lake to learn to guard against her tendencies to wander and, if such learning were possible, in what setting it could best have occurred. Nor did the judge inquire whether the District's statute itself gave independent value to preserving freedom or how substantial a risk of self-destruction must be proved before the court should lock someone up, possibly for life, against her will. If it had looked at these other concerns, the court might have given fuller attention to other possible dispositions-including the suggestion of Judge Bazelon that Ms. Lake merely be required to carry an identification card ( 364 F.2d at 661)-to decide whether, on balance, some sacrifice in the degree of immediate protection was desirable to give more adequate service to other legislative values.

60. In May 1966, the National Institute of Mental Health sponsored a three-day conference for seventy-five persons from seventeen countries largely devoted to discussing methods for evaluating community mental health programs. The conference led to the publication of a helpful collection of essays: CoMmuniry MENTAL HEalth: An International Perspective (R. Williams \& L. Ozarin ed. 1968). A second volume of essays on the same theme was published in the same year: CoMprEHENsive MENTAL 
tive efficacy of hospitalization and community alternatives is slight, ${ }^{01}$ enough studies now exist to provide some guidance to judges and others concerned with making decisions about appropriate placements for mentally ill persons. The studies by no means reach precisely the same conclusions. They do, however, suggest as a body that the acceptance by courts of an obligation to search for less restrictive alternatives to hospitalization would not be a hollow gesture. Indeed, the evidence is sufficiently strong that committing judges might wisely consider as a rule of thumb ordering some form of treatment other than hospitalization first and imposing hospitalization only if community treatment fails. ${ }^{62}$

Let us look a little at what is known. As is stated above, in disposing of any given case a judge is likely to wish to serve one cluster of goals revolving around the protection of the individual and society and a second cluster revolving around the treatment of the patient so that protection will not be needed in the future. It is the tension between these goals-the difficulty of providing treatment and protection simultaneously-that will often make a judge's task of deciding among alternatives so perplexing.

Viewed solely in terms of the goal of protection, hospitalization offers many obvious benefits. When an ill person poses a physical danger to himself or others, hospitalization erects more effective protections than any other form of disposition. It provides immediate respite to family members worn out by his disturbing behavior. ${ }^{03}$ Removed to a place distant from his family and from population centers, $^{64}$ the ill person can find total shelter from relationships he

Health: The Challenge of Evaluation (L. Roberts, N. Greenfield \& M. Miller ed. 1968). See also Flanagan, Evaluation and Validation of Research Data in Primary Prevention, 41 AM. J. ORTHOPSYchiatry 117 (1971).

61. See, e.g., the complaint of Freyhan, Clinical Aspects of the Revolution in Mental Health Services, CoMprehensive PsxchiatrX, Vol. 11, No. 1, Jan. 1970, at 1, 2. Some of the few controlled studies are discussed at text accompanying notes 105-10 infra.

62. See B. Pasamanick, F. Scarpitti \& S. Dinitz, supra note 46 , at 107 , who found that their study, discussed at text accompanying note 105 infra, gave support to the "contention of the proponents of community mental health care that the function of the mental hospital should be to treat only those patients for whom community care, even when continuous and intensive, fails, and greater supervision is required."

63. Some professionals have stressed the benefits to the family as a real value of hospitalization. See, e.g., CoMmitte of the AMERICAN Neurological Associstion for THE INVESTigation of Eugenical Sterilization, Eugenical Sterilization: A ReorientaTION OF THE PROBLEM 57-58 (1936): "It is safe to say that when a patient is placed in an institution, the social order is enhanced and that the family can go about their life business with more effectiveness and greater comfort."

64. "Another common characteristic [of twenty-two representative public hospitals examined in an American Bar Foundation study] is that in most states the hospitals 
had found impossible to manage. He can live on a locked ward with staff alerted to the control problems he may pose and empowered to administer whatever tranquilizing medication seems desirable.

The very reliability of these benefits of hospitalization may imperil the success of efforts to encourage judges to order less restrictive dispositions. A judge impressed by the advantages hospitalization offers for protection and isolation may overlook or devalue the more intangible prospects for serving the second range of goals relating to treatment, for which other dispositions may offer substantial advantages. Just as the more easily grasped financial savings from various highway routes may overshadow the more elusive considerations regarding their probable impact on the environment, just as male judges may find that Miss Montana's bust overwhelms the runnerup's more considerable musical talents, so the protection offered by locked wards may seem more certain and easily measured-and thus more compelling-than the care and treatment provided through a community mental health center ${ }^{65}$ The danger that the interests of treatment will be overlooked in favor of those of protection redoubles in the face of pressures a judge may feel to err on the side of caution. Little acclaim will come to him for ten aggressive patients successfully treated in the community and little condemnation for ten harmless patients needlessly confined, but condemnation (and guilt) may hound him for one ill person released to the community who commits a serious assault.

For these reasons, before some judges will be likely to try less restrictive alternatives to hospitalization they may demand convincing assurances along three lines directly relating to the state's goals in imposing compulsory care: first, that, in many cases, the mentally ill person will need no protection from himself and society will need no protection from him; second, that, even to the extent that a judge finds that protection must be assured, forms of supervision short of round-the-clock hospitalization may be adequate; and, finally, that, for purposes of treatment, hospitalization is hobbled by many in-

are located away from the population centers where most of their patients resided." R. ROCK, M. JACOBSON \& R. JANOPAUL, supra note 2, at 69 .

65. A colleague, Yale Kamisar, has suggested that another tragic example of the triumph of the concrete over the intangible is provided by the decision-making processes leading up to the Bay of Pigs, as described by Arthur Schlesinger:

[T] he advocates of the adventure had a rhetorical advantage. They could strike virile poses and talk of tangible things-fire power, air strikes, landing craft and so on. To oppose the plan, one had to invoke intangibles-the moral position of the United States, the reputation of the President, the response of the United Nations, 'world public opinion' and other such odious concepts.

A Thousand Days 255-56 (Houghton Mifflin Co. ed. 1965). 
herent shortcomings while community-based programs may offer much hope.

As to the first of these assurances, judges (and the community at large) need to understand that only a small portion of the mentally ill are overtly and imminently suicidal and that even fewer pose dangers to the persons or property of others. ${ }^{60}$ Indeed, as a group, persons labeled mentally ill may be less likely to engage in aggressive conduct than the rest of the community who are considered sane. ${ }^{67}$ Of course, a judge who conducts a hearing for a sullen patient and learns from a seemingly well-informed psychiatrist that the man is dangerous may believe himself ill-placed to decide that this man is not one of the dangerous few. He should nonetheless consider just how sullen he himself would feel under comparable circumstances and insist on a rigorous demonstration by the doctor of the bases for his prediction.

Even when the judge finds protection mandatory, he may find that community resources can provide the protection. He should be especially receptive to community programs when the danger posed is not assault or suicide but the more typical case of an ill person's inability to care for himself adequately. The ill person who needs protection because he cannot prepare food for himself or cannot be relied upon to dress sufficiently warmly may well be able to receive such protection through dispositions short of confinement. Social workers placed in single occupancy buildings, ${ }^{68}$ visiting nurses, systems of telephone contact, day or night hospitalization programs, or foster-home care may all serve to provide protection and to detect when a person has become so incapacitated that full-time inpatient care may be necessary.

Even if judges can be brought to recognize, at an intellectual level, that fewer ill people need custodial protection than is com.

\footnotetext{
66. See Hearings Before the Subcomm. on Constitutional Rights of the Senate Comm. on the Judiciary, 91st Cong., 2d Sess. 321 (1970) (statement of Dr. Sherman Kieffer, Director, National Center for Mental Health Services, Training, and Research, St. Elizabeth's Hospital, Washington, D.C.): "A number of studies conducted or sup. ported by the [National Institute of Mental Health] have demonstrated that an ex. tremely small percentage of civilly committed patients meet the statutory standard of danger to themselves or others to an extent that in our judgment necessitates inpatient care."

67. See H. Brill \& B. Malzberg, Statistical Report on the Arrest Record of Male Ex-Patients, Age 16 or Over, Released from New York State Hospitals During the Period 1946-48 (N.Y. Dept. of Mental Hygiene (undated)), referred to in Conley, Conwell \& Arrill, An Approach to Measuring the Costs of Mental Illness, 124 Asr. J. PsyChIATRY 755, 759 (1967): "If only the more serious forms of mental disorder are accepted, then there is some evidence that the disease may inhibit criminal tendencies."

68. See J. Shapiro, supra note 50.
} 
monly believed and that outpatient care can often provide the necessary protection, the key to fundamental change in judicial attitudes toward hospitalization may lie in infusing in judges an understanding of the dangers of hospitalization and the hopes for outpatient treatment. When examining the capacity of their state hospitals for offering treatment, judges may, of course, find some encouraging aspects. Many hospitals have reorganized to provide intensive care to the newly admitted and have reduced their total patient population and the average length of patient stays." "Therapeutic communities" in which the patients play a role in decision-making have in some hospitals provided patients new senses of self-reliance and self-respect. ${ }^{70}$ Much effort has been made to brighten the atmosphere of hospital wards-through handicrafts, holiday parties, fresh paint, and more attractive clothing. Wards once locked have now been opened.

In many respects, however, much of this new programming seems a beguiling coat of varnish over the intractable obstacles to successful treatment of persons in large public mental hospitals. Though hospitals may appear worse than they are because they become the repository for many whom other health programs reject as too difficult to treat, ${ }^{71}$ most hospitals are in fact ill-suited today to provide adequate care. They remain distant from the communities they serve, which standing alone seems to exert an influence on a patient's chances for recovery. ${ }^{72}$ With few exceptions, they suffer from woeful

69. In 1971, for the sixteenth consecutive year, population in state and county mental hospitals declined. Since 1964 the rate has been accelerating. Total population on June 30,1971 , was 308,024 . See $\mathrm{H}$. Bethel and R. Redick, supra note 1 , at 1 . According to the Bethel and Redick study, the reasons for the decline include

increased availability and utilization of alternate care facilities for the aged; increased availability and utilization of outpatient and aftercare facilities; gradual reduction in the length of stay of admissions; introduction of community mental health centers; affiliation of community mental health centers with State mental hospitals; introduction of more effective screening procedures to prevent inappropriate admissions, administrative changes such as the introduction of the geographic unit system; and deliberate administrative efforts to reduce the resident population.

Id. at 2.

70. See Wedge, supra note 20.

71. Glass, Philosophies, Not Laws, Determine Admissions Practice, 18 Hosprtal \& Community Psychitrit 234, 235 (1967) (Dr. Glass was the director of Oklahoma's Department of Mental Hygiene).

72. One study of two state hospitals in Wisconsin found a direct relation between the distance of a patient from his home and the length of his stay in a mental hospital, due in substantial part to the hospital's desire for certainty increasing with the geographic distance from the patient's home. Weiss, Macauley \& Pincus, Geographic Factors and the Release of Patients from State Mental Hospitals, 123 AM. J. Psychiarry 408 (1966). 
understaffing, overcrowding, and physical decay. ${ }^{73}$ All classes of professionals are in short supply. ${ }^{74}$ In virtually all hospitals, psychiatrists control admission, treatment, and release of patients, ${ }^{75}$ but few doctors graduating from American medical schools today are willing to work in such hospitals. ${ }^{76}$ As a result, a high proportion of psychiatrists in the state hospitals are foreigners who are trained -and apparently trained inadequately-in foreign medical schools and who possess only a halting command of the language of their patients and an even dimmer understanding of the communities to which their patients will return. ${ }^{77}$ Individual psychotherapy is nearly nonexistent, group therapy limited. ${ }^{78}$ Heavy reliance rests on medication (which, of course, can generally be administered out of the hospital) and on creating a rehabilitative "milieu," a supportive and curative environment. ${ }^{79}$ A warm atmosphere is, of course, highly desirable simply to render the lives of patients more nearly bearable. Such an atmosphere may indeed be an indispensable predicate to successful inpatient therapy. Unfortunately, however, almost no data

73. See note 18 supra. See also Presidential Address of H. Solomon to the American Psychiatric Association in 1958, quoted in Freedman, supra note 22, at 492: "The large mental hospital is antiquated, outmoded, and rapidly becoming obsolete. We can still build them but we cannot staff them. Therefore we cannot make true hospitals of them." "

74. No standards for staffing levels have been widely accepted. The American Psychiatric Association last published its position on patient-staff ratios in 1958. AMERICAN Psychiatric Assn., Standards for Hospitals and Glinics (1958). More recent editions of their positions on standards have eschewed specific minimum ratios. See, e.g., Amertcan Psychiatric Assn., Standards for Psychiatric Facilitiss vii (1969). On the other hand, by their own later publications, it is clear that most state hospitals still do not meet their earlier standards. Compare, e.g., American Psychiatric Assn., Eleven Indices, Table 3, at 15 (1971), with American Psychlatric Assn., Standards for HosPITALS AND Clinics, Appendix B, at 44 (rev. ed. 1958).

75. That psychiatrists intend to keep it that way can be inferred from AMERicaN Psychiatric Assn., Standards for Psychiatric Facilitifs 7 (1969): "It must be realized that physicians have the ultimate responsibility for patient care and that they are trained to assume that responsibility."

76. See H. Rome, Barriers to the Establishment of Comprehensive Community Mental Health Centers, in Communtry PsychistRY, supra note 21, at 31, 37. Dr. Rome saw the low salaries and heavy case loads that account in part for the unattractiveness to young doctors of working in the large public hospitals also likely to discourage the best young doctors from working for public outpatient clinics.

77. See Lavin, The Foreign Doctor Influx, Medical Economes, Feb. 17, 1969, at 263.

78. In the American Bar Foundation study, the authors commented that "[i]n no hospital visited did the number of patients undergoing active treatment exceed 10 to 15 per cent of the total patient population." R. Rock, M. JACobson \& R. JANorAut, supra note 2 , at 70 .

79. See M. Greenblatt, R. York \& E. Brown, From Gustodial to Therapeutic Patient Care in Mental Hosprrals (1955); Murphy \& Hunt, Milieu Therapy: Theoretical and Practical Considerations in Its Application, in The Psychiatric Hospital AS A Social System 176-84 (A. Wessen ed. 1964); Cameron, Nonmedical Judgment of Medical Matters, 57 GEO. L.J. 716, 731-33 (1969). 
exist to support the claims for any lasting therapeutic impact of milieu therapy standing alone, ${ }^{80}$ and in many cases the term seems no more than a dangerous euphemism to justify inactivity. The hospital locks bedroom doors during the day to bring patients out into healthy contact with each other; instead of sleeping in their own beds, the patients sleep on benches or under pool tables in the day room.

Even if states devoted greater resources to improving hospital care, there are certain dangers to the isolation of hospitals that inIproved staffing probably cannot cure. Nearly all long-term hospital patients exhibit flatness of response, withdrawal, muteness, and loss of motivation. ${ }^{81}$ Once believed to be part of the degenerative process of mental illness, these phenomena are now universally acceptedeven by public hospital administrators ${ }^{82}$ - as responses to hospitalization itself superimposed on the difficulties of illness. ${ }^{83}$ These observable attributes of the long-term patient reflect his sadly altered view of himself, for he often loses even more fully than he had before hospitalization his sense of self and self-esteem, his feeling of control over his own life, and his capacity to love. (Picture yourself, if you can, already upset, suddenly placed in baggy, hospital-issue clothing in a noisy dormitory with dozens of strangers and with a staff, neatly dressed, before whom you must line up to be given your cup of medicine. Then picture yourself in the same setting for five years.)

Institutions also have a dehumanizing impact on staff, which aggravates the position of the patient, for the temptation becomes almost irresistible for staff to subvert individual-treatment goals to

80. R. Stuart, Critical Reappraisal and Reformulation of Selected "Mental Health" Programs 12-13 (paper delivered at First Banff International Conference on Behavior Modification, Banf, Canada, April 3-5, 1969 (mimeo)). Cf. Rouse v. Cameron, 373 F.2d 451,459 (D.C. Cir. 1966) (suggesting doubts about the extent to which "milieu therapy" alone may fulfill a patient's right to treatment).

81. Visit any hospital yourself or see, e.g., Mendel, On the Abolition of the Psychiatric Hospital, in Comprehenstve Mental Health: The Challenge of Evaluation, supra note 60 , at $237,239-40$.

82. See, e.g., D. Vail, Dehumanization and the Institutional Career (1966) (Dr. Vail was the Medical Director of the Minnesota Department of Public Welfare); Glass, supra note 71, at 235 (Dr. Glass was Director of the Oklahoma Department of Mental Hygiene).

83. The literature on the harmful impacts of long-term hospitalization is now vast. Books dealing in whole or substantial part with the subject include $R$. BARTON, INstrtutional Neurosis (2d ed. 1966); R. Cancro, The Schizophrenic Reactions: A Critique of the Concept, Hospital Treatment, and CuRrent Research (1970); E. Goffrian, Asylums (Aldine ed. 1962); Milbank Memorial Fund, Proceedings of the ANNuAl Conference 195\%, AN Approach to the Prevention of Disability from Chronic Psychoses (1958); D. VAIL, supra note 82; J. Wing \& G. Brown, InstitutionALISM AND SCHIZOPHRENIA (1970). 
meet the demands of institutional management. ${ }^{84}$ Patients will often be forced to line up before an office door once an hour to receive a cigarette, or fed when they are not hungry, or denied the opportunity to decorate their own rooms. ${ }^{85}$

Such staff and patient responses to hospitalization greatly hamper efforts to equip persons in that setting to cope more effectively with the world they left. In the view of one state medical director of public welfare, treatment in the large public hospital is like "rescuing a drowning man, teaching him to ride a bicycle, and then putting him back in the water." 86 Adapting to a choiceless environment may indeed prove crippling in the world of choice. A public hospital director testified recently about a patient who, after a long period of hospitalization, made a visit outside the hospital and literally could no longer bring himself to choose what he would have for lunch. ${ }^{87}$

The longer the patient stays in the hospital the more pronounced the likely impact of isolation on him $^{88}$ and the less likely his family is to welcome his return. ${ }^{89}$ One possible-though not certain-indication of the dependency created by extended hospitalization is the extremely high rehospitalization rate for persons released. In 1969, the most recent year for which figures are available, nearly half of those admitted to state and county mental hospitals in the United States had previously been patients in the same sort of hospitals, the majority of them within the previous twelve months. ${ }^{90}$ All the haz-

84. See E. GofFMan, supra note 83, at 74-83.

85. D. VAII, supra note 82, at 118. Dr. Vail, then Medical Director of the Minnesota Department of Public Welfare, collected these and many other examples of dehumanizing and dehumanized staff behavior within his hospitals.

More recently, Stephen Cain, a reporter for the Detroit News, posed as a patient for a few days at a large state mental hospital in Michigan. He acknowledged the difficulties of administering hospitals but reported several incidents of insensitivity of hospital staff. Among them was being awakened on the first night of his stay by a staft member who asked him the color of his eyes, a fact apparently needed for the files. Inside the Mental Ward, Detroit News, June 28, 1971, 1A, col. 2, at 15A, col. 2.

86. D. VAIL, supra note 82 , at 67.

87. Deposition of Dr. Walter Fox, Superintendent and Area Director of Mental Health at the Mental Health Institute, Mount Pleasant, Iowa, filed in Wyatt v. Stickney, 325 F. Supp. 781 (M.D. Ala. 1971), quoted in Pretrial Memorandum of Amici Curiae, American Psychological Association, American Orthopsychiatric Association, and American Civil Liberties Union, at 18-19 n.8 [hereinafter Pretrial Memorandum].

88. Mendel, On the Abolition of the Psychiatric Hospital, in Comprehensive Mental Health: THE Challenge of Evaluation, supra note 60, at 237, 242.

89. See Pokorny \& Bentinck, A Study of Relatives' Views of State Mental Hospital Patients, 50 SOcIAL CASEWORK 519, 525 (1969) (a questionnaire administered to the families of 1537 patients in Texas mental hospitals found, among other things, that families were more favorably disposed toward the release of a recently admitted patient than a long-term patient).

90. See C. Taube, Admissions to State and County Mental Hospitals by Previous Care in These Hospitals, United States 1969, Statistical Note 33, Survey and Reports 
ards of hospitalization thus far mentioned apply to both the voluntarily and involuntarily committed. For those involuntarily confined, the process of commitment itself further hampers any efforts to treat, for many doctors believe that compulsory confinement greatly impedes any effort to establish a therapeutic relationship. ${ }^{91}$

Warning doctors about these many dangers of hospitalization, Dr. Stanley Yolles, for many years the Director of the National Institute of Mental Health, once stated, "Let the doctor beware, who does not now realize the amount of mental illness he helped either to cause or to intensify by institutionalizing mental patients." 92

If brought to appreciate these facts, judges might become more wary of placing mentally ill persons in hospitals. Even if a judge decides in a given case that he is interested solely in protection, he should recognize that the benefits of the temporary protection provided by hospitalization may well be outweighed by the danger that the stay will only serve to make the patient less able to cope with the outside world and render him more dangerous to himself or others if the hospital releases him..$^{93}$ Such fears have been repeatedly and justifiably raised with respect to prisons $^{94}$ and juvenile facilities, ${ }^{95}$

Section, National Institute of Mental Fealth (1970). For additional earlier data, see Zolik, Lantz \& Sommers, Hospital Return Rates and Prerelease Referrals, 18 ARcH. Gen. Psychiatry 712 (1968).

91. See, e.g., R. Rock, M. Jacobson \& R. Janopaut, supra note 2, at 61 . In a recent deposition, Dr. Israel Zwerdling, Executive Chairman of the Department of Psychiatry, Albert Einstein College of Medicine, and Director of Bronx State Hospital, Bronx, New York, described some of the difficulties of treating the involuntarily committed patient:

The great bulk of the treatment effort becomes an effort, really, to clarify for the patient that his behavior is a manifestation of illness and that he needs treatment. He questions and resists every suggestion. ... He feels himself put upon and resent [s] being in the hospital and the great bulk of the transactions between staff and patient are around the issue of does he really need treatment, rather than around the issues of the illness itself and its treatment.

Quoted in Pretrial Memorandum, supra note 87, at 16.

92. Yolles, Mental Health's Homoeostatic State: A New Territory, 7 INTL. J. PsyCHIATRY 327, 328 (1969).

93. See Covington v. Harris, 419 F.2d 617, 625-26 (D.C. Cir. 1969) (Bazelon, J.)

94. See Levin, Crime and punishment and social science, THE PUBLrc Interest, Spring 1972, at 96, 97 (summarizing fifteen studies of recidivism) (emphasis omitted): Offenders who receive probation have significantly lower rates of recidivism than those who have been incarcerated, and incarcerated offenders receiving shorter sentences generally have a somewhat lower recidivism rate than those receiving longer sentences. With a few exceptions, these differences persist when one controls for type of offense, type of community, and offender's age, race, or numbers of previous convictions.

95. See Levin, Policy Evaluation and Recidivism, 6 L. \& Soc. REv. 17 (1971) (discussing California random placement experiment finding much lower recidivism rate for group assigned to probation with intensive counselling than for group assigned to institution); Empey \& Rabow, The Provo Experiment in Delinquency Rehabilitation, in L. Radzinowicz \& M. Wolfgang, Crime and Justice 266, 280-82 (1971) (comparable experiment in Utah). 
and many of the same considerations-the stigma, the isolation, the dependency, the development of unconstructive habits of livingapply as fully to mental hospitals.

Little of the writing on the impacts of hospitalization has dealt with short-term stays ${ }^{98}$-an unfortunate gap in research, since, to an increasing extent, judges are committing ill persons for shorter stays and hospitals are retaining patients for shorter periods. ${ }^{07}$ Even short compelled hospitalization probably does pose dangers. Without adequate aftercare programs, readmission to the hospital even after a short stay is highly likely. ${ }^{98}$ Moreover, the process of adjusting to a hospital by withdrawal or by other defenses undermining the individual's capacity to perform in the outside world occurs rapidly in many patients, ${ }^{99}$ and thus for them any hospitalization, however brief it is planned, may stretch into long-term residence. To the extent a patient needs a rest and a place to calm down, there is substantial doubt whether the rest (on a forced basis) needs to be nearly as long as the typical two or three months of initial commitment or whether it is best provided in the vast, threatening, and often distantly removed state hospital, rather than in a general hospital or community clinic nearer home. ${ }^{100}$

Community-based care not merely avoids the nearly inevitable deleterious effects of hospitalization but also may offer positive values of its own. For the schizophrenic and the senile, who constitute a substantial majority-over sixty per cent-of patients in mental hospitals, ${ }^{101}$ and for the suicidal and the assaultive, who probably

96. For a few exceptions, see authorities cited in note 100 infra.

97. See, e.g., Raskin \& Dyson, Treatment Problems Leading to Readmission of Schizophrenic Patients, 19 ARCH. GEN. Psychutru 356 (1968).

98. Id. See also Miller, Retrospective Analysis of Posthospital Mental Patients World, 8 J. HEALTh \& SOciar Behavior 136 (1967); Friedman, Von Mering \& Hink, Intermittent Patienthood, 14 ARch. GEN. PsychIATRY 386-29 (1966); Wing, Morbidily in the Community of Schizophrenic Patients Discharged from London Mental Hos. pitals in 1959, 110 BRrT. J. PsychIATRY 10-12 (1964).

99. See E. GoFman, supra note 83 , at $14-71$ (describing the immediate undermining of an individual's self-image that institutionalization often entails).

100. Mendel, On the Abolition of the Psychiatric Hospital, in Comprenensive mental Health: The Challenge of Evaluation, suppra note 60, at 242-43 (average stay on a "30-day" ward went down to 10.2 days and then lower as staff attitude adjusted to viewing hospitalization "as a crisis intervention rather than as a definite treatment." The shorter the patient's stay the more likely he was to succeed on the outside.) See also Weisman, Feirstein \& Thomas, Three-Day Hospitalization: A Model for Intensive Intervention, 21 ARCH. GEN. PsYchiATRY 620 (1969).

101. In 1967, $49.2 \%$ of the resident patients in public hospitals were diagnosed as suffering from one of the schizophrenic reactions and an additional $12.4 \%$ were diagnosed as suffering from "diseases of the senium." G. Koons, Projected AgeDiagnostic Composition of the Resident Patient Population in State and County Mental Hospitals-1973, Statistical Note 8, Survey and Reports Section, National Institute of Mental Health, Figure 1, at 5 (1969). 
stir the greatest public concern, sufficient research exists to serve as generally encouraging guides to the effectiveness of community-based therapy.

Persons diagnosed as suffering from schizophrenia ${ }^{\mathbf{1 0 2}}$ fill half the beds in the nation's public mental hospitals. ${ }^{103}$ Persons so diagnosed often face lives of acceleratingly frequent episodes of hospitalization ending in permanent residence. ${ }^{104}$ Of several studies of efforts to break this cycle, the most thorough and balanced is probably the study by Benjamin Pasamanick and others conducted in Louisville in 1961 and $1962 . .^{105}$ It is a study of sufficient significance to justify slightly extended discussion. In Pasamanick's study, all patients brought to a state hospital in Louisville, diagnosed as schizophrenic, and found by the staff to be in need of hospitalization were referred instead to a clinic operated by Dr. Pasamanick. Screening out only the small number whom the clinic staff feared suicidal or assaultive or whose families refused to provide supervision at home, the clinic staff randomly divided the referred patients into three groups. One group returned to their homes on medication, a second returned home on placebos, and a third returned to the state hospital where all of them had been initially approved for admission. On a periodic basis, a nurse visited those sent home. ${ }^{108}$ The clinic handled 152 patients over an eighteen-month period.

Despite the fact that the average patient in the study had undergone two prior periods of hospitalization, the results of the study were quite encouraging. Over seventy-seven per cent of those returned home on drugs succeeded in remaining out of the hospital throughout the period of the study. Thirty-four per cent of those on placebos also succeeded. Nearly all who failed did so right away. The results are even more encouraging in light of the experience of the randomly hospitalized patients. The hospital to which these patients were sent was considered moderately progressive. Treated like other patients in the hospital, all returned to their homes dur-

102. No universally accepted chemical criteria exist for the diagnosis of "schizophrenia"; so far as I have ever been able to perceive, the label of "schizophrenia" is applied to persons whose views of themselves or external facts differ from the view of others and who often behave in a manner frightening to others but consistent with their "distorted" view of reality. See generally R. LAING, THE DIvIDEd SELF (1965).

103. See note 101 supra.

104. Average total stay for hospitalized schizophrenic patients in the United States in the mid-1960's was eleven years. B. Pasamanick, F. Scarpitiri \& S. DinItz, supra note 46 , at vii.

105. See id., a long book devoted to describing the study.

106. Neither the nurse nor any other staff member was aware which patients were receiving medication, though all were aware that some patients who thought they were were not. 
ing the course of the study after an average stay of eighty-three days. The hospital group, despite the care received in the hospital, had a failure rate after release that was higher by a statistically significant margin than that of either of the two groups left in the community. In short, hospitalization seems to have worsened rather than improved these patients' chances of remaining in the community. 'Though some ethical doubts can be raised about the experimenters' methods, ${ }^{107}$ the Pasamanick study demonstrates the potential for community treatment for the schizophrenic, since it found that by all measures of success, including subjective judgment about domestic functioning and social participation, ${ }^{108}$ persons in home care performed as well or better than the hospital control group. ${ }^{100}$

What is most encouraging is that the results of the Pasamanick study are supported by more recent studies ${ }^{110}$ _even by studies of

107. The staff lied to participants and their families in two significant ways that were probably indispensable to the success of their experiment: First, they lied at the time of initial placement in saying that the staff of the clinic had decided that a certain form of placement had been selected as appropriate for the patient, implying something more than the random placement decision that in fact occurred; second, they permitted one of the groups to believe it was receiving medication when it was receiving a placebo and continued the charade even after it became clear that persons on medication were succeeding better in the community.

108. As with the penal system, where recidivism (in terms of either new arrests or convictions) has been used as the principal measure of success, so in the field of mental health, especially when dealing with schizophrenics, the principal measure has been the rate of rehospitalization. Of course, rehospitalization does not indicate with any certainty the quality of life for a person between hospitalizations; even less does the avoidance of rehospitalization indicate that the once-ill person is functioning to his own satisfaction or the satisfaction of others. Assuming continuation of the trend away from hospitalization (and imprisonment), more and more need exists for developing more subtle measures of success. See R. GLAsscote, J. GudEMAn, \& R.

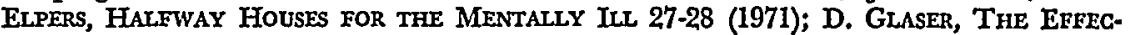
tiveness of a Prison ANd Parole System 5 (1964).

109. I have only one major doubt about the accuracy of the study's findings. The authors point to the higher failure rate of those who were randomly assigned to the hospital and later released. This group apparently did not receive the same medication and nurses' visits after release that one group of the clinic's patients did. See B. Pasamanick, F. ScarpitTi \& S. Dinirz, supra note 46, at 107-08, 254. The apparent absence of aftercare for most of these patients may fairly reflect mental hospital pro. grams in most states but does not provide an accurate indication whether this group might conceivably have performed even better than Pasamanick's medicated group if provided the same care after release from the hospital.

110. See the following studies:

(1) J. Hoenig \& M. Hamilton, The Desegregation of the Mentally Ill (1969) (British study finding high success rate in treating mentally ill persons in the community; when inpatient care necessary, short stays at inpatient units of general hospital fully served).

(2) Claghorn \& Kinross-Wright, Reduction in Hospitalization of Schizophrenics, 128 AM. J. PsYchIATRY 344 (1971) (high success rate when hospital-released patients followed closely by after-care center but not when not followed at all);

(3) Driemen \& Minard, Prerelease Planning, 24 ARch. GEN. Psychiatry 87 (1970) (high success rate when follow-up care provided for patients released from hospital);

(4) Wilder, Levin \& Zwerling, A Two-Year Follow-Up Evaluation of Acute Psychotic 
persons released from hospitals after fifteen and twenty years of residence. ${ }^{111}$ Summarizing recent research, one scholar has said: "With drug treatment most psychiatrists feel that the great majority of patients can be managed on an outpatient basis or with only a very brief hospitalization."112 To be sure, community-based treatment of the schizophrenic is not wholly free of danger. Distressing evidence does exist in some cases that the treatment of an ill person in the community succeeds for that person but contributes to mental health problems of other family members. ${ }^{113}$ Recognition of this danger has led to greater efforts to work with families as a unit to prevent someone else in the family having to take over the family illness. ${ }^{114}$ Moreover, especially for the schizophrenic, it is important not to expect too much. Given the current resources devoted to mental health programs, the limited attainments of even lavishly funded programs, and the late stage in their lives (and illnesses) when many persons come to a court's attention, the court must not assume that it has failed when patients placed in the community return intermittently

Patients Treated in a Day Hospital, 122 AM. J. Psychiatry 1095 (1966) (patients randomly assigned to inpatient hospitalization or to day-patient care; nonhospitalized group performed better after two years); and

(5) Zolik, Lantz \& Sommers, Hospital Return Rates and Prerelease Referrals, 18 ARCH. GEN. PSychiatry 712, 713 (1968) (study in large city found $56 \%$ return rate within one year for persons released from hospitals who were not referred to community mental health service, $33 \%$ rate for those who were so referred, and $18 \%$ rate for those placed in foster home or foster care).

111. Herjanic, Stewart \& Hales, The Chronic Patient in the Community: A TwoYear Follow Up of 338 chronic Patients, 13 CANAdian Psychiarric Assn. J. 231 (1968). On the other hand, one study found that some long-term patients who succeed in the community do so at the cost of placing an enormous burden on community resources because of their need for so much help. Kraft, Binner \& Dickey, The Community Mental Health Program and the Longer-Stay Patient, 16 Arck. Gen. Psychiatry 64 (1967).

112. Letter to the author from John M. Davis, Feb. 14, 1972, on file with the Michigan Law Review. Dr. Davis is the co-author of a review of the literature on the effectiveness of drugs in treating persons suffering from mental illness. D. KLEIN \& J. Davis, Diagnosis and Drug Treatment in Psychiatrx (1969).

113. See Grad, a Two-Year Followup, in Community Mental Health: AN InterNational Perspective 429-54 (R. Williams \& L. Ozarin ed. 1968). The Grad study involved a comparison over a two-year period of the mental health programs in two neighboring English cities, one relying much more than the other on hospital-based treatment. The patients in the city relying on outpatient care were able to survive fairly well in the community and, to that extent, the conductors of the study were encouraged. On the other hand, the heavy reliance on outpatient care was found to have had a deleterious impact on the mental health of other family members. Id. at 433 (Table 4) and at 451-52. See also M. Hamilton, The Hospital and the Household, id. at 416. (A second British study finding that community placement placed a variety of burdens on families of the mentally ill; burdens were heavier in cases in which the patient had been hospitalized for substantial periods (id. at 419, 422, 426-27).)

114. On the family rather than the individual as the appropriate unit for understanding the process of schizophrenia, see generally $R$. LAING \& A. ESTERSON, SANITX, MADNESS AND THE FAMILY (1964). 
to its attention or, though remaining in the community, do not become wage-earning contributors to the public purse.

Aged persons also may suffer from a complex range of problems labeled as mental disorders. ${ }^{115}$ Large numbers of them ${ }^{110}$ have been forced to spend their last years, idle and unhappy, ${ }^{117}$ on the wards of public mental hospitals. Today, few defenders of compulsory mental hospitalization for the aged remain. In most states, persons committed to a public mental hospital for the first time late in life are there largely by default, not by medical preference. ${ }^{118}$ Often state legislatures have responded to their needs only with provision for warehousing. If nursing homes and foster homes were built and adequately staffed, they would probably be filled without any need for prompting from a principle of less restrictive alternatives. Indeed, as alternatives have developed the rate of mental hospitalization of the aged has steadily declined.110

Even without adequate nursing facilities, courts may find good reason to resist ordering indeterminate commitment for the aged. When, as in the case of the aged, treatment to reverse the disease process is impossible and the patient poses no risk to the lives of others, the only sensible (if not uniformly commendable) purposes to attribute to the legislature in permitting compulsory care are that it wishes to spare the individual from suffering, his family from the burden of caring for him, and the community from the pain of watching him die before its eyes. Judges too often believe that forced hospitalization well serves all three goals. But at least its service of the first-sparing the individual from suffering, the only goal most judges (and relatives) would comfortably acknowledge-is highly dubious: courts that claim to be concerned with the aged

115. Group for the Advancement of Psychiatry, the Commttee on Aging, PsyChIATRY AND THE AgED: AN INTROductory Approach, RPT. No. 59, at 545.59 (1965) (listing and discussing the range of psychiatric diagnoses).

116. As recently as 1967 , slightly more than $30 \%$ of patients in public mental hospitals were 65 and over. Only about $40 \%$ of the 65 -and-over group, however, carried principal diagnoses of "diseases of the senium." G. Koons, Projected Age-Diagnostic Composition of the Resident Patient Population in State and County Mental Hospitals-1973, Statistical Note 8, Survey and Reports Section, National Institute of Mental Health, Table 1, at 3, Figure 2, at 6 (1969).

117. I recently encountered an eloquent understatement:

I asked a 69-year old geriatric patient, who had $51 / 2$ years earlier been admitted

to the Ypsilanti State Hospital, how she felt about being a patient in a state mental institution. She responded soberly and unhesitatingly, "well, it's not what I had planned for my retirement."

Paper by J. Doersch, graduate student in Social Work, quoted on cover of Annual

Report, Project Transition (March 1971). See also note 120 infra.

118. R. Rock, M. JACOBSON \& R. JANOPAUI, supra note 2, at 70-71.

119. See Redick, State Trends in First Admission and Resident Patients, State and County Mental Hospitals 1966-1968, Statistical Note 14, Survey and Reports Section, National Institute of Mental Health, at 2, 10 (Table 2D) (1970). 
person's happiness need to be more careful than they have been in comparing the suffering (including starvation, if you will) that may be risked through freedom with the suffering produced by the boredom of confinement and by the label, affixed just in time to die with, of being crazy. ${ }^{120}$

Of the efficacy of community treatment for mentally ill persons who are believed suicidal or assaultive, little can be said with assurance. Pasamanick and others studying community therapy have excluded such persons because they had no special mission to include them and because such persons might injure themselves and others, as well as the goodwill surrounding the researcher's project. Most writing about the treatment (as opposed to the characteristics) of the suicidal seems to take the form of psychiatrist's insights and anecdotes rather than statistics. ${ }^{121}$ Judges may or may not find such information helpful guidance in making decisions, depending on whether they prefer the false assurance of statistics or the false assurance of a psychiatrist's clinical impressions expressed as immutable truths. About one facet of the care of the imminently suicidal almost all writers agree: some period of hospitalization appears almost always appropriate. ${ }^{122}$ Judges dealing with such patients need to be quite discriminating, however, for there appear to be some patients who fare better in a general hospital or clinic than in a large state hospital and others whose hospitalization stays, whatever the setting, should be kept brief because of their hostile reaction to them. ${ }^{123}$ Avoidance of hospitalization for the suicidal may, until treatment methods improve, come less frequently from judges' finding an alternative adequate than from legislatures, judges, and doctors concluding that it is inhumane to preserve life at the cost of depriving it of dignity. California's legislature has wisely imposed a fixed limit of twenty-eight days on commitments of the suicidal, arbitrary in almost every sense but its responsiveness to human dignity. ${ }^{124}$

As I have indicated, mentally ill persons believed dangerous to

120. Writing of persons, many of them old, who live in single resident occupancy housing in New York City, Joan Shapiro found that some regarded institutionalization as "an unsatisfactory alternative to suffering, deterioration, and death." J. SHAPIRo, supra note 50, at 124. See also id. at 141.

121. See, e.g., Seale \& McNichol, Treatment of the Suicidal Patient: Community Psychiatry Approach, 58 S. MED. J. 1159, 1160-61 (1965). See also note 123 infra.

122. Group for the Advancenient of Psychiatry, Grisis in Psychiatric HospitalizaTION, RPT. No. 72, at 53, 67 (1969) ("Few would disagree that psychiatric hospitalization is the treatment of choice for an individual who is actively suicidal.").

123. See, e.g., E. Schneidman, N. Farberow \& C. Leonard, Suicide-Evaluation and Treatment of Suicidal Risk Among Schizophrenic Patients in Psychiatric Hospitals, Dept. of Medicine \& Surgery Medical Bulletin, Veterans Administration (Feb. 1, 1962). 124. CaL. WeLF. \& InstNs. Code \$§ 5250, 5260 (West Supp. 1972). 
others probably are not. ${ }^{125}$ Even when a particular ill person is believed dangerous, courts should not on that ground alone conclude hospitalization is the most satisfactory disposition. Although apparently no one has conducted a controlled study specifically evaluating community alternatives to civil commitment for mentally ill persons believed dangerous, judges need not approach the question of community placement for such persons in a vacuum. The greatest inspiration for reliance on community-based treatment should spring from the vastly developed, if understaffed, probation system of our criminal courts. In many states today, most convicted felons return to the community on probation. In 1970, in Michigan, for example, sixty-one per cent of those convicted of felonious larceny and thirtytwo per cent of those convicted of manslaughter were granted probation. ${ }^{126}$ A principal reason for the widespread reliance on probation applies as well to the use of alternatives to civil commitment: not merely the unavailability of institutional space, but also the belief that the community is better protected in the long-run by treating the subject in his home setting than by removing him from it and that this long-run protection is more important than any immediate protection that might result from incarceration.

Most, if not all, civil commitment judges sadly lack any staff comparable to the probation officers attached to their states' criminal courts, and the problems of supervising the acutely ill, dangerous person may be far different from those of supervising most persons convicted of crime. On the other hand, to the extent that we have specific information about mentally ill persons believed dangerous it indicates that states have been employing unnecessarily restrictive forms of confinement for them.

A recent decision of the United States Supreme Court ${ }^{127}$ had the effect of forcing the state of New York to transfer 992 patients from Matteawan, an especially secure hospital for the criminally insane, to regular mental hospitals elsewhere in the state. Researchers followed all 992 patients for a year. ${ }^{128}$ They found that all but seven of

125. See notes 66-67 supra. See also Birnbaum, A Rationale for the Right [to Treatment], 57 GEO. L.J. 752, 767 (1969).

126. See Michigan Dept. of Corrections, Criminal Statistics (1970), Tables A3A, A3B, B1. Accord, Bureau of Criminal Statistics, Crime and Delinquency in Californin1969, at 37 (1970) (of those convicted of felonies in California in 1969, 39.8\% were placed directly on probation and an additional $27.8 \%$ given short, fixed jail terms followed by probation).

127. Baxstrom v. Herold, 383 U.S. 107 (1966).

128. Hunt \& Wiley, Operation Baxstrom After One Year, in Associstion of THE Bar of the City of New York, Mental illness, Due Process and the Crminal DeFENDANT 221 (1968); Morris, The Confusion of Confinement Syndrome: An Analysis of the Mentally Ill Criminals and Ex-Criminals by the Department of Correction of the State of New York, 17 Bufralo L. Rev. 651 (1968). 
the 992 had fared well enough in less secure, often unlocked facilities that the new hospitals had not seen a need to seek their return to more secure facilities. Indeed, 147 were discharged to the community, far more than would have been released from Matteawan in an average year, and those who remained in regular hospitals seemed indistinguishable to the staffs from the general hospital population. The study may provide little firm indication of how the same men would have fared if never hospitalized at all or if placed initially in a minimum-security hospital, but it should increase courts' skepticism both about claims that a person is dangerous and about claims that hospitalization is necessary. ${ }^{129}$

We have now examined several classes of mentally ill persons and seen that, for most of them, community-based treatment offers substantial promise. If courts accept an obligation to explore alternatives to hospitalization, they will have to bring these generally encouraging findings to bear on the facts of specific cases. They will have to worry whether a particular patient will voluntarily come to a clinic for the medication prescribed for him and whether the patient's family, though nodding repeatedly that they "want whatever is best," will unconsciously undercut the patient's attempts at community survival. ${ }^{130}$ They can in short rarely be confident of success when making decisions about community placement. They can, on the other hand, be confident of a high risk of failure-at least in terms of treatment-when they order hospitalization. Thus, like judges in criminal cases who now rely on probation for persons much more likely than those facing civil commitment to be dangerous to the community, civil commitment judges could wisely adopt a policy of community placement and treatment except when confronted with overwhelming evidence of an immediate need for highly secure, protective custody.

\section{The Legal Obligation To Search for Alternatives to Hospitalization}

Even if alternatives to hospitalization seem promising, their desirability will not alone, of course, create the legal handles for ap-

129. See generally P. ScheddEMander \& C. KanNo, The Mentally ILl OfFendeRA Survey of Treatmenr Programs (1969). A nonevaluative review of current treatment programs, this study found a high reliance on custodial care but a desire on the part of many professionals working in them for additional treatment modalities. $I d$. at 58-59.

130. On techniques for handling the uncooperative patient, see Coleman, Therapy of the "Inaccessible Mentally Ill Patient, 48 MeNTAL HyGIENE 581 (1965). For examples of the complex family pathologies involved in cases in which one family member has been hospitalized as schizophrenic, see the case studies in R. LAING \& H. Esterson, SANITY, MADNESS, AND THE FAMILY (1964). 
pellate courts to compel or even permit their use by committing courts. The notion that government should not constrict the freedom of its citizens to any greater degree than the community needs require may seem so elementary in a nation prizing individual freedom as barely to require discussion. The excess, if truly excess and believed by the legislators to be excess, is a form of tyranny. Jeremy Bentham, ${ }^{131}$ Vice-President Spiro Agnew, ${ }^{132}$ and the American Civil Liberties Union ${ }^{133}$ have each regarded such restraint on governmental action a premise of decent government. The charge of American courts, however, is neither to vindicate basic political principles nor even to thwart tyranny. When interpreting statutes, including commitment statutes, courts may find maxims of good government a helpful guide in determining the legislature's probable purposes, but the legislature may quite simply desire or condone the unnecessary. In determining the constitutionality of regulations or government action, courts must find a specific constitutional provision that permits them to strike down the legislation or invalidate the government's acts.

\section{A. The Undetected Flexibility of Existing State Codes ${ }^{184}$}

Every American jurisdiction authorizes the involuntary hospitalization of mentally ill persons. The states place the power to confine in judges or commissions ${ }^{\mathbf{1 3 5}}$ charged with applying widely varying 1948):

131. J. Bentham, The Princtples of Morais and Legislation 170-71 (Hafner ed.

... But all punishment is mischief: all punishment in itself is evil. Upon the principle of utility, if it ought at all to be admitted, it ought to be admitted in as far as it promises to exclude some greater evil.

... It is plain, therefore, that in the following [case] punishment ought not to be inflicted.

. . Where it is needless: where the mischief may be prevented or cease of itself, without it: that is, at a cheaper rate.

(Emphasis in original, footnote omitted).

132. Speaking recently before the Mllinois Farm Bureau, Mr. Agnew quoted, with approval, James Fenimore Cooper: "Individuality is the aim of political freedom. By leaving its citizens as much freedom of action as comports with order and the rights of others, the institutions render him truly a free man.' " Speech reprinted in Agnew's Blast at Behaviorism, PsYCHOLOGY TODAY, Jan. 1972, at 4.

133. See Neier \& Fabricant, Legislative Memorandum No. 1 of N.Y. Givil Liberties Union, Subject: S. 5227, at 12 (1970) (urging New York legislature to adopt civil commitment bill using least restrictive means).

134. For aid in researching this section and other sections dealing with state codes, I am grateful to Paul Russell, a student at the University of Michigan Law School.

135. Nine states rely on nonjudicial forms of commitment in all cases. Twenty-six others permit nonjudicial commitment in some cases. See S. BRAKeL \& R. Rock, supra note 2, at 55. Typically, nonjudicial commitment is handled by a mental health board or commission. Id. at 55-57. (For a study of the workings of such a commission, see 
and generally inexplicit statutory criteria and with following complex timetables of notice, examinations, and hearings. Considerable diversity exists among the states in these procedures, ${ }^{136}$ but the pattern of involuntary-commitment codes having congealed in this country before the recent movement toward community-based programs, painful uniformity appears in the limited dispositional tools other than hospitalization with which legislatures have explicitly equipped their courts. ${ }^{137}$ Several state codes do permit commitment to the care of relatives or friends $\mathbf{s}^{\mathbf{1 3 8}}$ and all provide for the appointment of guardians for ill persons' property, which may serve in some cases as an alternative to commitment. ${ }^{139}$ Only about nine jurisdictions, however, explicitly empower their committing authorities to prescribe treatment through facilities other than inpatient hospitals. ${ }^{140}$ Most of these nine are of recent date and several are well

Note, Contemporary Studies Project: Facts and Fallacies About Iowa Civil Commitment, 55 IowA L. REv. 895 (1970)). In a few states open-ended commitment is possible simply on the basis of a physician's certificate reviewed almost solely for form by a judge without a full hearing automatically provided. See S. BRAKEL \& R. Rock, supra, at 57-59. See also R. Rock, M. JAcobson \& R. JANOPAUL, supra note 2, at 41. The latter form of commitment may well be infirm (see State ex rel. Fuller v. Mullinax, 364 Mo. 858, 269 S.W.2d 72 (1964)), and offers little opportunity for an effective examination and review of alternatives. In any event, $I$ have in this paper referred to the committing authority generally as a court and only rarely made reference to special problems under other systems for commitment.

136. See S. Brakex \& R. Rock, supra note 2, Tables 3.2-3.6, at 72-97; R. Rock, M. JACOBSON \& R. JANOPAUL, supra note 2, chs. 2, 5, 8.

137. See Bleicher, Compulsory Community Care for the Mentally Ill, 16 CuEv.MAR. L. REv. 93 (1967).

138. See, e.g., ILr. ANN. STAT. ch. 911/2, \$§ 8-12, 9-61 (Smith-Hurd 1966); ORE. REv. STAT. $\$ 426.130$ (1963); WASH. REv. CODE $§ 71.02 .240(4)$ (1959).

139. See S. BRAREL \& R. Rock, supra note 2, at 250-302.

140. See Cal. Welf. \& INSTNS. Code $\S 5358$ (West Supp. 1972); Colo. Rev. Stat. ANN. § 7I-I-11(2) (1963) (porver to commit to "any suitable place"); D.C. CoDE \& 21-545 (Supp. 1971) (power to commit to hospital or order "any other alternative course of treatment which the court believes will be in the best interest of the person or the public"); Int. ANN. STAT. ch. 911/2, § 9.6 (Smith-Hurd Supp. 1971) (court directed to "consider the alternative forms of treatment which are desirable for and available to the patient, including but not limited to hospitalization"); KAN. STAT. ANN. \$\$ 59. 2917(D), -2902(9) (Supp. 197I) (court may place person in care of mental health clinic, nursing home, physician, "or any other institution or individual authorized or licensed by law to give care or treatment to patients"); N.M. STAT. ANN. § 34-2-13 (Supp. 1971) (permitting court to use hospital or other suitable clinical facilities); N.C. STAT. ANN. § 122-63 (1964), \& 122.63-1 (Supp. 1971) (permitting orders for outpatient care or treatment at local facilities, including community mental health centers); OHIO REv. CODE ANN. \$ 5122.15 (1970) (as drafted, the best of all: specifically authorizes use of community mental health clinics and private psychiatric care); PA. STAT. ANN. tit. 50, § $4406(\mathrm{~h})$ (1969) (permitting partial hospitalization or outpatient treatment). See also "Appendix A. Examples of Less Drastic Means Statutes," Wexler, Scoville, et al., The Administration of Psychiatric Justice: Theory and Practice in Arizona, 13 ARIz. L. REv. 1, 243-49 (1971).

In addition, Massachusetts, while not empowering courts to employ alternatives, does order periodic review by the hospital, at which time explicit consideration of 
drafted and worthy of emulation at least if altered to require the use of alternatives in appropriate cases.

Despite the antiquity of many codes and their failure to charge committing courts explicitly to employ community alternatives, virtually all state codes do invite a reading that their judges should avoid unnecessary hospitalization. Many individual judges, eager to spare ill persons avoidable suffering, no doubt find ways to reduce commitments by dismissing proceedings when a satisfactory alternative plan has been suggested by an attorney or family member or by committing the person to the hospital with the understanding that release will soon follow on a status similar to parole. ${ }^{\mathbf{1 4 1}}$ Only a few state courts have, however, considered whether their codes impose an affirmative obligation to seek to avoid unnecessary commitment, and only courts in the District of Columbia and New Mexico142 have given answers of more than a sentence or two in length. Though the experience in these two jurisdictions has not been encouraging, it does indicate what imaginative courts could do within the confines of existing codes.

The most innovative court in the nation in dealing with mental health issues has been the United States Court of Appeals for the District of Columbia Circuit. It is thus unsurprising that this court, guided by its Chief Judge, David Bazelon, decided en banc in 1966 the first case finding committing courts obligated to explore alternatives. The District of Columbia code provides that, if a court finds a person mentally ill and "likely to injure himself or others if allowed to remain at liberty," it may order "his hospitalization for an indeterminate period or order any other alternative course of treatment which the court believes will be in the best interest of the person or of the public."143 In 1966 on the basis of this language, the court in

alternatives, including community resources, is to occur. See MAss. ANN. LAws ch. 123, § 4 (Supp. 1970). See also CAL. Werf. \& InSTNs. CodE \& 10053.5 (West Supp. 1971) (setting up system to provide aftercare social services for persons released from hospitals to prevent "unnecessary" readmission). I can find no reported constructions on the scope of courts' powers under these statutes, nor do I have information, except in the District of Columbia and Ohio, concerning the extent of court reliance upon them. See text accompanying notes $276-80$ infra.

141. See, e.g., Mich. STat. ANN. \& 14.827(1) (1969) (providing for release from hospital on "convalescent status," which under Michigan law permits the hospital to reincarcerate an ill person without hearing if the convalescent release proves unsatisfactory).

142. Lake v. Cameron, 364 F.2d 657 (D.C. Cir. 1966); State v. Sanchez, 80 N.M. 438, 457 P.2d 370 (1968), appeal dismissed, 396 U.S. 276 (1969); Fhagen v. Miller, 65 Misc. 2d 163, 173, 317 N.Y.S.2d 128, 139 (Sup. Ct. 1970), affd. per curiam as modified, 36 App. Div. 2d 926, 321 N.Y.S.2d 61 (1971), affd., 29 N.Y.2d 348, 278 N.E.2d 615, 328 N.Y.S.2d 393 (1972).

143. D.C. CODE § 21-545 (1967). 
Lake v. Cameron ${ }^{144}$ found that the committing court not merely had an obligation to consider the range of "other alternative course[s] of treatment"145 but also to place the patient in the least restrictive of the alternative courses found suitable.

After adopting this expansive view of the statute, the court then suggested a dazzling array of specific alternatives the government and committing court might consider for Ms. Lake, a doughty sixty-one year old woman suffering from brain damage associated with senility, who was alleged to have a tendency to wander and become confused.140 Suggested alternatives included dispositions as mild as requiring Ms. Lake to carry an identification card on her person as well as more substantial programs of nursing care, home health services, foster care, and private care through welfare payments. The court recommended seeking information and services from a whole telephone book full of agencies, including the local departments of public health, public welfare, vocational rehabilitation, and police as well as private family service organizations and social workers. ${ }^{147}$

The very range of the alternatives appears to have alarmed several judges into dissenting. "A United States [district court] in our legal system," complained then Circuit Judge Warren Burger in dissent, "is not set up to initiate inquiries and direct studies of social welfare facilities or other social problems." 148 Rather, according to the dissenters, the court is set up to deal with facts "adduced by parties" and to resolve legal issues "raised by them in pleadings." 149 In passing the statute, Congress did not intend to transmute the court into an administrative agency for proceedings involving the mentally ill. The dissenters appear to have forgotten that the same district courts are involved daily in complex social inquiries of almost precisely the same sort in making the decisions whether to place persons convicted of crime on probation and, if on probation, under what sorts of conditions.

The Supreme Court of New Mexico agreed with Judge Burger when essentially the same issue came before it two years later in State $v$. Sanchez. ${ }^{150}$ It first found the language of New Mexico's

144. 364 F.2d 657 (D.C. Cir. 1967).

145. 364 F.2d at 660 .

146. See the discussion at note 59 supra and text accompanying notes 358-61 infra. 147. $364 \mathrm{~F} .2 \mathrm{~d}$ at 661-62. For further discussion of the Lake case, see note 59 supra. 148. 364 F.2d at 663. One critic has agreed with Judge Burger's reasoning with regard to the inadequacy of courts and suggested removing courts from the commitment process. Parker, Lake v. Cameron, Involuntary Civil Commitment-Storm Warnings, 4 FAMILY L.Q. 81, 84, 86 (1970).

149. 364 F.2d at 663 .

150. 80 N.M. 438, 457 P.2d 370 (1968), appeal dismissed, 396 U.S. 276 (1969). 
statute different from the District of Columbia's and then, pointing to Judge Burger's dissent, observed that New Mexico's district courts were no better suited than the federal courts in the District of Columbia to undertake complex inquiries into alternatives to commitment.

Much about the New Mexico decision is disheartening. The case involved inordinately compelling circumstances for seizing an alternative: No one claimed that Sanchez posed threats to others but simply that he was unable to care for himself; and his niece indicated to the court her willingness to provide the necessary care. ${ }^{151}$ Even more distressing was the court's interpretation of the New Mexico statute, especially since so many other states have commitment criteria closely similar to New Mexico's..152

Like many states, New Mexico permits the involuntary commitment of two classes of mentally ill persons: those who are "likely to injure [themselves] or others if allowed to remain at liberty," and those who are "in need of custody, care or treatment in a mental hospital and lack sufficient capacity to make responsible decisions with respect to [their] hospitalization."163 Interpreting this language, the New Mexico court might sensibly have held-and other courts might sensibly still hold - that in order to decide whether a person is likely to be dangerous "if allowed to remain at liberty," the committing court must determine whether community resources exist that will permit him to remain at liberty without being dangerous..$^{164}$ If such resources exist, then the person can be "allowed to remain

151. The New Mexico supreme court omitted in Sanchez any discussion of the facts. Simply referring to Sanchez as a person found "dangerous to himself," the court invited visions of a man seeking to slash off his ears or jump off bridges. Apparently Mr. Sanchez was a mild, forty-two-year old Mexican-American who had become ill while serving in the Army during the Korean War. (Interview with William S. Dixon, counsel to Sanchez, May 19, 1972.) Suffering from schizophrenia characterized by elaborate delusions, Sanchez did appear to Veterans Administration psychiatrists to be dangerous to himself, but only in the narrow sense of being unable to care for himself. The state district court ordered him committed despite the fact that at his hearing a Veterans Administration psychiatrist testified that Sanchez was not dangerous to others and, more strangely, despite the testimony of his niece that she and the rest of his family would be willing to assume responsibility for his care. Exactly why the court committed him or the Veterans Administration wanted him committed is unclear. The trial court, like most courts in these cases, made no findings and the psychiatrist apparently gave no opinion on the adequacy of the care the niece and others in his family could provide. Sad to say, despite his niece's willingness to care for him, Sanchez was then transferred from a Veterans Administration hospital in New Mexico to another in Colorado.

152. See S. BRAkEL \& R. Rock, supra note 2, at 36, Tables 3.2, 3.4, 3.6, at 72-97.

153. N.M. STAT. ANN. \& 34-2-5(G) (Supp. 1971).

154. This position was, in substance, adopted in Cross v. Harris, $418 \mathrm{~F} .2 \mathrm{~d} 1095$, 1100 (D.C. Cir. 1969). 
at liberty" without being dangerous. Similarly, the court might sensibly have held that before concluding that a person is "in need of custody, care or treatment in a mental hospital," the committing court must determine whether the person's needs can be as well or better served through other available forms of care. If they can be, the person is not in need of care or treatment "in a mental hospital."155 Furthermore, in requiring a finding that the ill person lacks capacity to decide responsibly about his need for hospitalization, the New Mexico statute can be seen as evincing concern for what a rational person would wish for himself if he contemplated that he might someday suffer a comparable illness. Among equally effective treatment modes, most rational persons would probably pick the one that preserved a maximum degree of freedom of movement.

As stated above, many other states have commitment criteria closely comparable to New Mexico's and their courts could wisely take the broader view suggested here. Even a state that permits commitment merely on a finding that a person is ill and "should be committed"156 could wisely find that the "should" implies an inquiry into current sound medical practice and calls for hospitalization only when necessary to serve the state's goals. In short, no state requires the commitment of all ill persons, and the definition of those ill persons who are appropriate for commitment could in almost all jurisdictions be found to contemplate some inquiry into the necessity for hospitalization in order to serve the state's purposes. Such an inquiry may have been superfluous in an era when hospitalization was thought necessary for treatment of nearly all mental illnesses, but could appropriately be seen as mandatory under the expansive language of most acts in an era such as today when the desirability of hospitalization for serving the state's own interests is gravely in question.

Nevertheless, other state appellate courts may well prove as unwilling as New Mexico to scrape the barnacles off their statutes.

155. A section of the New Mexico commitment code unmentioned by the court permitted its courts to use "hospitals or other suitable clinical facilities," thus making clear the legislature's recognition of the possible acceptability of forms of treatment outside the hospital. N.M. STAT. ANN. \& 34-2-13 (Supp. 1971). More recently enacted than the basic commitment section, this provision seems in mild conflict with the provision that all those fitting the criteria for compulsory treatment "shall" be hospitalized.

156. See, e.g., NEB. REv. STAT. \$ 83-328 (1958) ("mentally ill and should be admitted to a hospital"); LA. REv. STAT. tit. 28, § 55 (West 1969) (if "the judge believes that the patient should be committed") and tit. 28, § 53(A) (West 1969) (commitment when "in the best interest of the patient and the community"); Wrs. STAT. $\$ 51.05(1)$ (1967) ("mentally ill or infirm and should be sent to a hospital for the mentally ill or infirm"). See generally S. BRAKEL \& R. Rock, supra note 2, Table 3.2, at 72-76. 
Apart from wishing to shield their courts from the added burden of the exploration, most state appellate courts in opinions dealing with other commitment issues have found broad discretion in their committing judges under the elusive criteria provided by statute. ${ }^{167}$ Courts seem rarely to have been pressed by litigants to read substantive limits into their commitment codes and rarely to have inquired on their own. Although language stressing the necessity for careful review of commitments does abound in appellate decisions, ${ }^{158}$ the concern expresses itself in most cases primarily through ensuring that the committing court complied with all the procedural niceties - the right number of examining physicians, the proper notice, the proper timetable-and not through defining the criteria the committing judges are to apply or reviewing the committing judges' application of the criteria. ${ }^{159}$

Such appellate court devotion to process might be acceptable if the committing judges themselves deserved broad discretion over substance like administrative agencies charged with a complex area of regulation. ${ }^{160}$ Unfortunately, few committing judges deserve such deference. Most have time-consuming responsibilities other than civil commitments-probating wills or trying criminal and civil cases —and, like the appellate judges, concern themselves primarily with form rather than substance. ${ }^{161}$ As in many human relations, committing judges, frightened perhaps by the prospect of what they might find if they looked beneath the surface, convince themselves that the patient rests in good hands if the proper rituals have been observedthe legal how-are-yous, thank-yous, and goodbyes.

Of course, even if states did find that their codes required that alternatives be examined, grave problems would remain in assuring

157. See, e.g., In re Hobart, 76 Ohio Abs. 80, 81, 145 N.E.2d 205, 206 (Ohio Ct. App. 1956), appeal dismissed, 355 U.S. 21 (1957); In re Nagle's Estate, $418 \mathrm{~Pa} .170,172,210$ A.2d 262, 264 (1965). There are, of course, exceptions. See, e.g., Dodd v. Hughes, 81 Nev. 43, 398 P.2d 540 (1965) (discussing symptoms and behavior that justify commitment).

158. See, e.g., State v. Sanchez, 80 N.M. 438, 440, 457 P.2d 370, 372 (1968), appeal dismissed, 396 U.S. 276 (1969) (the court stated, "If there is any class of cases which should be conducted with the utmost care to observe all the requirements of the statute, it is those cases conducted for the purpose of determining the sanity of a citizen." 80 N.M. at 440,457 P.2d at 372 . It then went on to review only the procedure and none of the substance of the commitment.); In re Wojtisiak, 375 Mich. 540, 134 N.W.2d 741 (1965).

159. See cases cited in note 158 supra.

160. Cf. Packard Motor Car Co. v. NLRB, 330 U.S. 485 (1947). Perhaps the hospital doctors should be the ones treated as having the skills of a regulatory agency; it is before the court, however, and not the doctors that a patient has a right to a hearing.

161. See Pfrender, Probate Court Attitudes Toward Involuntary Hospitalization: A Field Study, 5 J. FamiLY L. 139 (1965). 
that judges receive adequate information about the alternatives and possess adequate powers, not merely to explore alternatives, but also to require the staffs of the alternative facilities to cooperate. ${ }^{162}$ To what extent state constitutions or the United States Constitution can supply the force to compel the search for alternatives and to assure the adequacy of the processes for carrying out the search forms the core of the remainder of this article. But the Constitution, even more than statutes, requires a receptive court to bring it into new territory. The peculiarly constricted posture that state appellate courts have adopted in reviewing decisions under their own commitment codes may foreshadow a similar posture when they deal with arguments based on the Constitution.

\section{B. Constitutional Obligation}

\section{The Principle of the Least Restrictive Alternative in Constitutional Adjudication}

Stated succinctly, the principle of the least restrictive alternative would require courts to hold that, under state constitutions and the Constitution of the United States, committing courts and agencies must refrain from ordering hospitalization whenever a less restrictive alternative will serve as well or better the state's purposes. The appropriateness of insisting on the exploration of alternatives to hospitalization can be best understood by a brief exposition of the range of occasions when courts have insisted on the use of alternatives in other settings.

The United States Supreme Court has confronted hundreds of cases in which a party complains that the government has reached farther than it needed to achieve its purposes. ${ }^{163}$ The Court has responded variously-sometimes overturning legislation when convinced a less restrictive alternative existed and should have been used, ${ }^{104}$ sometimes refusing to listen at all to arguments about alternatives, ${ }^{165}$ and sometimes mentioning less restrictive alternatives without making clear their relation to the decision rendered. ${ }^{166}$

162. See pts. IV. A. \& B. infra.

163. So far as I can find, the only general survey of the Supreme Court's use of the principle is Wormuth \& Mirkin, The Doctrine of the Reasonable Alternatives, 9 UTAF L. REv. 254 (1964). The article is a most helpful review of the cases up through 1963.

164. See note 173 infra and accompanying text.

165. See notes 171 \& 177 infra.

166. Sometimes the Court has mentioned alternatives the state could easily have used simply to demonstrate (in race cases, for example) the disingenuousness of the reasons the state advanced for having a rule, but without implying that it was be- 
At least in this century, the Justices have not regarded the principle that government should intrude as little as necessary into the lives of citizens as a principle independently worthy of veneration. ${ }^{107}$ In recent decades, when the Court has insisted on the use of a less restrictive alternative, it has done so because of its concern for a constitutionally protected interest at stake (for example, free expression), not because of loyalty to a view (sanctified in the Constitution, if at all, only in the little-used ninth and tenth amendments) that that government governs best which governs least. With their eyes focused on a particular social concern-public safety, free expression, free exercise of religion-the Justices have used the principle as simply one of several useful tools available to them to accommodate important constitutional and legislative interests when they conflict. When a consistent pattern of reliance on the principle appears, it reflects more a period of consistency in the Court's attitude toward a particular constitutional guarantee than an adherence to the principle itself.

In first amendment cases, particularly first amendment cases in which expression is commingled with conduct, the Court has on a few occasions upheld state and federal legislation curtailing free expression when it found no reasonable alternative available for serving the legislature's goal. It thus recently upheld criminal sanctions for the burning of draft cards, finding "the incidental restriction on free speech ... no greater than essential" for serving the federal government's needs in raising armies. ${ }^{108}$ More frequently, however, particularly when the expression at issue involved words rather than conduct, it has done just the reverse, striking down laws, even though the alternatives available to the state were plainly less adequate than the regulation chosen. ${ }^{169}$ The constitutional interest

cause of the alternative that it struck down the statute. See, e.g., Hunter v. Erickson, 393 U.S. 385, 392 (1969). In cases dealing with evidence obtained through objectionable police practices, the Court has sometimes mentioned alternatives that the police could have used seemingly in part to soften the blow of its holding a practice unconstitutional, but again without implying that it was because of the alternatives that the Court had held the practice unconstitutional. See United States v. Wade, 388 U.S. 218, 239 (1967) (police line-ups); Miranda v. Arizona, 384 U.S. 436, 467 (1966) (confessions).

167. For an early statement of the principle stated generally, see Anderson v. Dunn, 19 U.S. (6 Wheat.) 204, 231 (1821).

168. O'Brien v. United States, 391 U.S. 367, 377 (1968). See also United Pub. Workers v. Mitchell, 330 U.S. 75, 100-01 (1947), in which the Supreme Court upheld Hatch Act restrictions on political activities of federal employees despite availability of less restrictive (though probably somewhat less effective) alternatives. $C f$. Sherbert v. Verner, 374 U.S. 398, 407 (1963) (state must "demonstrate that no alternative form of regula. tion would combat such abuses without infringing First Amendment rights" (decision based on the free exercise clause)).

169. See discussion in Note, Less Drastic Means and the First Amendment, 78 Yale L.J. 464 (1968). The Note is critical of the application of the principle in first 
in preserving a greater level of free expression simply outweighed the legislative interest in having any regulation stronger than the weaker alternative available to it. In Butler $v$. Michigan, ${ }^{170}$ for example, the Court held unconstitutional a statute forbidding the sale of books "tending to the corruption of the morals of minors," since it prevented adults from access to the same reading matter. The law was stricken even though a narrower statute-one forbidding the sale of such materials to minors-was almost certain to be less effective in keeping pornography and gore from coming before the eyes of youths.

In commerce clause cases, the Court has been more solicitous of the state's interests, but has still insisted in most, but not all, ${ }^{171}$ cases that the state protect its local interests by the means that interfere to the least extent necessary with the flow of interstate commerce. South Carolina's stringent limitations on the width and net weights of trucks were upheld, despite a substantial impact on commerce, because the Court found that the state had no less restrictive means available to ensure safety on its old and narrow roads. ${ }^{172}$ Conversely, in Dean Milk Co. v. City of Madison, ${ }^{173}$ an ordinance in Madison, Wisconsin, forbidding the sale of milk not processed within a few miles of town was held unconstitutional in substantial part because the Court found that there were "reasonable" and "adequate" alternative means to protect the health of Madison's citizens without the city's totally banning the sale of outside milk.

In "substantive" or "economic" due process cases, the doctrine of reasonable alternatives has died, of course, with substantive due process itself. ${ }^{174}$ Whereas the Court in the late nineteenth and early twentieth century struck down many state regulations of business

amendment cases: "A precise evaluation of less drastic means is an uncommonly difficult task and with respect to the first amendment it is fair to say that the Supreme Court has never attempted it." Id. at 468-69.

170. 352 U.S. 380, 383-84 (1957). See also Schnieder v. Town of Irvington, 308 U.S. 147, 162 (1939); Martin v. Struthers, 319 U.S. 141, 147-49 (1943); Cantwell v. Connecticut, 310 U.S. 296, 311 (1940).

171. Wormuth \& Mirkin, supra note 163, at 260, found that the Court sometimes left to the state legislature the judgment whether a regulation affecting commerce was the least restrictive regulation available.

172. South Carolina St. Highway Dept. v. Barnwell Bros., 303 U.S. 177 (1938). More recently, the Court upheld an Arkansas statute requiring large crews on freight trains, despite claims that some of the crew members were unnecessary for safety or any other function, on the ground that the evidence regarding need was equivocal and was thus properly resolved through the legislative process. Brotherhood of Locomotive Firemen v. Chicago, R.I. \& P.R.R., 393 U.S. 129, 133-40 (1968).

173. 340 U.S. $349,354-56$ (1951).

174. Death came, after many serious wounds, in Olsen v. Nebraska, 313 U.S. 236, 246 (1941). See generally McCloskey, Economic Due Process and the Supreme Court: An Exhumation and Reburial, 1962 SuP. Cr. REv. 34. 
on the ground that they constituted illegitimate and unnecessary intrusions on legitimate activities-for example, the business of running a private employment service ${ }^{\mathbf{1 7 5}}$ or a railroad ${ }^{178}$ - the Court in recent decades has affirmed the legislature's prerogative to use any rational means it chooses to reach permissible state ends regardless of the asserted availability of lesser alternatives. In 1946, for example, the Court rejected out of hand a landlord's suggestion that the Court should strike down the application to his building of a New York law requiring automatic sprinkler systems in certain apartment houses because the landlord had installed a fully adequate fire alarm system: "Little need be said of the due process question. We are not concerned with the wisdom of the legislation or the need for it."177

As new concerns have caught the attention of the Court, the principle continues to serve as an aid in the resolution of conflict. In Aptheker $v$. Secretary of State, ${ }^{178}$ the Court relied on the federal right to travel to strike down an act of Congress that denied passports for travel outside the Western Hemisphere to members of organizations identified as subversive by the Subversive Activities Control Board. The Court found that the act swept unnecessarily broadly in that the passport denial did not turn on a finding of the degree of the members' participation in the subversive organization or on the purposes or place of the proposed travel. Similarly, in Shelton $v$. Tucker, ${ }^{179}$ the Court relied on the federal right of free association to invalidate an Arkansas law requiring school teachers to list all organizations to which they belonged. The Court, striving

175. See Adams v. Tanner, 244 U.S. 590 (1917). In Adams the Court struck down a Washington statute banning private employment agencies that exacted fees from persons they placed in jobs. The Court found that sanctions imposed on particular abuses of the agency would be adequate to protect the state's interests. 244 U.S. at 594. To my mind, Justice Brandeis convincingly demonstrated in dissent that the defects of the private employment services were most unlikely to be controlled through narrow regulations. 244 U.S. at 603-07.

176. Hannibal \& St. J.R.R. v. Husen, 95 U.S. 465, 472 (1878).

177. Queenside Hill Realty Co. v. Saxl, 328 U.S. 80, 83 (1946). The Court did not act consistently. In several earlier cases that might have been handled like Adams v. Tanner, 244 U.S. 590 (1917), discussed in note 175 supra, the Court refused to examine alternatives and stated that the determination of the need for a particular form of commercial regulation lay with the legislature. See, e.g., Jacob Ruppert v. Caffrey, 251 U.S. 264, 297-98 (1920); Purity Extract \& Tonic Co. v. Lynch, 226 U.S. 192, 204 (1912); New York ex rel. Selz v. Hesterberg, 211 U.S. 31, 40 (1908). Interestingly to me, the Court in each of these cases, except perhaps Selz, seems in fact to have been convinced through its tone that there were in fact no effective alternatives.

178. 378 U.S. 500, 512-14 (1964). See also Shapiro v. Thompson, 394 U.S. 618, 633-38 (1969).

In a recent decision holding unconstitutional under the equal protection clause Tennessee's durational residency requirement for voting, the Court again relied on the principle. Dunn v. Blumstein, 40 U.S.L.W. 4269, 4276-77 (U.S. March 21, 1972). 179. 364 U.S. 479 (1960). 
ardently to find a ground to invalidate legislation enacted as part of an effort to cripple the NAACP, 180 again claimed that there were "less drastic means" for protecting the state's "legitimate and substantial" interests. ${ }^{181}$

State appellate courts, though by no means uniform in their approach, have also found the principle of the least restrictive alternative useful in reaching accommodations between state legislative concerns and a federal or state constitutional interest. California's supreme court has struck down many state laws when alternatives existed that it believed would avoid injury to threatened federal and state constitutional interests, such as freedom of speech. ${ }^{182}$ The Supreme Court of Illinois has on several compelling occasions invalidated state legislation regulating purely commercial practices when the legislation seemed unnecessary or unduly broad to protect the state's interests. ${ }^{183}$ Other state courts, in other settings, have also

180. See H. KALVEN, The NEgRo AND the FIRST AMENDMENT 99-103 (1965).

181. In reaching his decision, Justice Stewart made a statement regarding lesser alternatives that has been frequently cited in more recent decisions:

In a series of decisions this Court has held that, even though the governmental purpose be legitimate and substantial, that purpose cannot be pursued by means that broadly stiffe fundamental personal liberties when the end can be more narrowly achieved. The breadth of legislative abridgement must be viewed in light of less drastic means for achieving the same basic purpose.

364 U.S. at 488. In both Aptheker and Shelton, as the dissents in each case point out acidly, the Court was probably wrong as a matter of fact in asserting that the government could have achieved its purposes more narrowly. 378 U.S. at 521, 527 (Clark, J. dissenting); 364 U.S. at 490, 494-95 (Frankfurter, J., dissenting). In each, the Court's real objection was that the statute would reach persons the government had no legitimate interest in reaching. But the fact that legislation may reach too many people does not necessarily mean that the legislature's ends could have been more narrowly achieved. It may be that only by reaching too many can the legislature be reasonably confident of reaching those it needs to. The Court's results in these two cases may still be justifiable but not on the basis of the principle it purported to apply. What the Court was doing in fact was weighing a federal constitutional interest in each case against the asserted legislative interest and deciding that the federal interest was more deserving of protection. Like many fat persons, several justices of the Court do not like to reveal what they weigh.

182. See, e.g., City of Carmel-by-the-Sea v. Young, 2 Cal. 3d 259, 466 P.2d 225, 85 Cal. Rptr. 1 (1970) (election disclosure law held, in part, an unnecessary intrusion on privacy); Fort v. Civil Serv. Commn., 61 Cal. 2d 331, 392 P.2d 385, 38 Cal. Rptr. 625 (1964) (restriction on political activities of county officers infringed unnecessarily broadly on first amendment rights); Parrish v. Civil Serv. Commn., 66 Cal. 2d 260, 425 P.2d 223, 57 Cal. Rptr. 623 (1961) (early morning raid intruded unnecessarily broadly on fourth amendment rights of welfare recipients); Wollam v. City of Palm Springs, 59 Cal. 2d 276, 379 P.2d 481, 29 Cal. Rptr. 1 (1963) (right of free speech unnecessarily curtailed by ordinance greatly restricting use of sound trucks).

183. See Schroeder v. Binks, 415 Ill. 192, 195-201, 113 N.E.2d 169, 170-73 (1953), and other cases discussed in Struve, The Less-Restrictive-Alternative Principle and Economic Due Process, 80 FARv. L. REv. 1463, 1471-73 (1967). Struve applauds the Hlinois courts' pattern of invalidating unnecessarily broad economic legislation. The Schroeder case, for example, dealt with a state statute, no doubt passed under pressure from the plumbers' unions, providing that a person could become a master plumber only through apprenticeship to a currently licensed plumber. 
insisted on the use of alternatives. ${ }^{184}$ On the other hand, a few state supreme courts have rejected the principle altogether. The Indiana supreme court, in upholding its state's Anti-Communism Act, stated angrily that testing the validity of a law, any law, by "a standard that 'less drastic means' might have been used" would be "a blatant assumption of a legislative function."185

A review of the many cases decided by the Supreme Court and by state courts yields many unfortunate and ill-analyzed opinions, ${ }^{180}$ but a solid core of sense endures. Particularly in a federal system such as ours, courts must often resolve conflicts between compelling, but competing, governmental and constitutional interests. When the legislative interest seems meager in relation to an impaired constitutional interest, the legislation may fall altogether, even when there is no acceptable available alternative. Conversely, when the interest advanced by the individual seems insubstantial in relation to a pressing state or federal legislative interest-for example, the legislature's concern for preserving lives as seen in the case of the landlord and his sprinklers-the legislation will often simply be upheld, with, at most, a statement that in this area it is for the legislature to decide what regulation is necessary. ${ }^{187}$ But when the Court feels it critical to protect both interests, the inquiry into alternatives and their effect on each of the competing interests may reveal different forms of regulation that permit the legislature's interest to be served either fully or substantially while removing or reducing the harmful impact to a constitutionally protected freedom.

The claim of the Indiana supreme court that inquiries by courts into alternatives involve a usurpation of the legislature's function is understandable but unsound. The legislature has, of course, an independent obligation to seek ways to minimize the impairment of constitutionally protected liberties, and courts ought to accord great weight to a legislature's assessment of the effectiveness of an alterna-

184. See, e.g., State ex rel. Superior Court v. Sperry, 79 Wash. $2 \mathrm{~d} 69,-, 483$ P.2d 608,613 (1971) (court order prohibiting newspaper publication of trial testimony that judge had ruled inadmissible held unnecessarily broad to prevent unsequestered jury from viewing prejudicial material); One Eleven Wines \& Liquors, Inc. v. Division of Alcoholic Beverages Control, 50 N.J. 329, 341, 235 A.2d 12, 19 (1967) (suspension of liquor license of bar permitting congregation of apparent homosexuals unnecessary to the protection of any legitimate state interest); Good Humor Corp. v. City of New York, 290 N.Y. 312, 319, 49 N.E.2d 153, 156 (1943) (prohibition on street peddling an unnecessarily drastic method for regulating abuses).

185. State v. Levitt, 246 Ind. 275, 285, 203 N.E.2d 821, 826 (1965).

186. See the discussion in notes 175 and 181 supra.

187. See note 177 supra and accompanying text. 
tive, when it has in fact undertaken such an assessment. ${ }^{188}$ Too often, however, no evidence exists that the legislature has given even a moment's thought to alternatives that might protect the threatened freedom and, even when it has considered alternatives, it often resolves the conflict in the end simply by yielding to political expediency. Courts are not above political expediency, but they may serve, at a minimum, as a second line of protection for endangered freedoms.

\section{The Few Civil Commitment Cases on Point}

The principle of the least restrictive alternative offers an obvious possible application to civil commitment. Through commitment, the state seeks to serve its traditional functions of protecting its citizens from injury and providing care and treatment for the ill. However compelling these concerns may be, commitment also intrudes on equally compelling constitutionally based interests of the individual: freedom of movement, freedom of association, and, as I will demonstrate at some length, freedom from physical confinement. The search for alternatives to hospitalization may reveal in individual cases ways that the state's interests can be fully served with little or no constraint on the individual's freedom-that is, in ways that protect almost fully both sets of interests.

Despite the obvious place for the principle in the context of civil commitment and despite the numerous cases above that might support its application, the United States Supreme Court, in a recent decision, may conceivably have foreclosed its application as a requirement of federal constitutional law. In Sanchez $v$. State, the New Mexico decision discussed earlier, ${ }^{189}$ the New Mexico supreme court abruptly rejected a constitutional argument for application of the principle, distinguishing without comprehensible explanation ${ }^{190}$ the Supreme Court decisions cited by Sanchez's lawyer. Sanchez appealed to the United States Supreme Court, relying on Shelton and numer-

188. See Brotherhood of Locomotive Firemen v. Chicago, R.I. \& P.R.R., 393 U.S. $129,133-40$ (1968).

189. See notes $150-55$ supra and accompanying text.

190. 80 N.M. at 441,457 P.2d at 373. The reasoning of the New Mexico court is somewhat obscure. Referring to first amendment cases such as Shelton and Lovell v. Grifin, 303 U.S. 444 (1939), the court said: "[T]he cases cited by appellant are distinguishable and involve situations where a statute is found unconstitutional because the legitimate purposes of the statute involved could be accomplished by a different statute, which would not violate constitutional liberties." 80 N.M. at 441 , 457 P.2d at 373. Then after listing the Supreme Court cases cited by appellant, the court simply stated, "The policy which counsel has denominated as that of 'Least Abridgement' has no application to the case before us." 80 N.M. at 441, 457 P.2d at 373. 
ous first amendment cases. The Supreme Court dismissed the appeal in a single sentence "for want of a substantial federal question."101 The dismissal constituted a disposition on the merits and thus may have obliterated any chance of establishing a federal constitutional obligation to search for alternatives.

Hope need not, however, be abandoned. As an understandable concession to its swollen docket, the Court has in recent decades summarily upheld lower court decisions by affirmance or dismissal, simply on the jurisdictional papers and without oral argument, in well over half the appeals that have come before it. ${ }^{102}$ To some observers, its practice in dismissing appeals now parallels closely its practice in denying petitions for writs of certiorari and should be accorded little more significance. ${ }^{193}$ On more than one occasion, the Court has dismissed an appeal for want of a substantial federal question and then within a few years dealt with the same issue at great length without citing its earlier dismissal as precedent. ${ }^{104}$

The Supreme Court of California in its recent decision holding unconstitutional its state's scheme of school financing found itself in somewhat the position I find myself here: it had to contend with a United States Supreme Court affirmance by order, without opinion, of a lower court decision reaching the opposite conclusion than the California court thought proper. ${ }^{195}$ The California court pointed to the Supreme Court's handling of appeals generally and to the inartful handling of the earlier case by its plaintiffs, both of which factors created a likelihood that the Supreme Court had not adequately appreciated the substantiality of the questions before it. ${ }^{108}$

191. 396 U.S. 276 (1969).

192. See R. Stern \& E. Gressman, Supreme Court Practice 194 (4th ed. 1969).

193. See Currie, The Three-Judge District Court in Constitutional Litigation, 32 U. CrII. L. REv. 1, 74 n.365 (1964) ("It has often been observed that the dismissal of an appeal, technically an adjudication on the merits, is in practice often the substantial equivalent of a denial of certiorari.").

194. One recent example is McGowan v. Maryland, 366 U.S. 420 (1961), in which the Court dealt at enormous length with the issue of the constitutionality of Sunday closing laws, ignoring six of its earlier decisions dismissing appeals from lower courts raising the identical issue. See, e.g., Grochowiak v. Pennsylvania, 358 U.S. 47 (1958) (dismissing appeal for want of a substantial federal question). A more recent example is Walz v. Tax Commr., 397 U.S. 664 (1970), in which the Court dealt with the merits of an attack on the exemption from the property tax of church-owned property, despite two prior dismissals for want of a substantial federal question of cases raising the same issue. General Fin. Corp. v. Archetto, 369 U.S. 423 (1962); Heisey v. County of Alameda, 352 U.S. 921 (1956).

195. Serrano v. Priest, 5 Cal. 3d 584, 615-17, 487 P.2d 1241, 1263-65, 96 Cal. Rptr. 601, 623-25 (1971). The case the court had to contend with was McInnis v. Ogilvie, 394 U.S. 322 (1969), affg. mem. McInnis v. Shapiro, 293 F. Supp. 327 (N.D. Ill. 1968).

196. Serrano v. Priest, $5 \mathrm{Cal}$. $3 \mathrm{~d}$ at 616-17, $487 \mathrm{P.2d}$ at 1264-65, $96 \mathrm{Cal}$. Rptr. at $624-25$. 
Courts could appropriately treat the Sanchez decision in a similar manner. Though the issue of requiring a search for alternatives was the only issue the Supreme Court was asked to address in Sanchez, the dismissal should not be seen as fully indicative of the Court's probable response to the question of alternatives if the issue is squarely before it again, fully briefed and argued. The Supreme Court of New Mexico had, it is to be remembered, accorded the issue brief and hasty treatment, and the Supreme Court of the United States had never decided any case challenging the traditional mechanisms for committing the mentally ill. Moreover, the jurisdictional papers for Sanchez, though citing several first amendment and commerce clause cases requiring the use of alternatives, appear in the light of hindsight to have devoted insufficient attention to demonstrating to the Court that civil commitment involved constraints on liberties of comparable importance. ${ }^{197}$

That the federal constitutional questions loom much larger than the Supreme Court implied is indicated by the fact that, since Sanchez, two federal courts (probably unaware of Sanchez) have indicated that the Constitution requires that alternatives to civil commitment be employed whenever effective for the state's needs. In 1969, in Covington v. Harris, ${ }^{198}$ Judge Bazelon, writing for the Court of Appeals for the District of Columbia Circuit, reaffirmed the court's holding in the Lake case $\mathrm{e}^{199}$ and went on to imply strongly that the Lake holding had roots in the Constitution:

The principle of the least restrictive alternative consistent with the legitimate purposes of a commitment inheres in the very nature of civil commitment, which entails an extraordinary deprivation of liberty .... A statute sanctioning such a drastic curtailment of the rights of citizens must be narrowly, even grudgingly, construed in order to avoid deprivations of liberty without due process of law.200

Except for a footnote citing Aptheker and quoting from Shelton, ${ }^{201}$ this passage was the sum of Judge Bazelon's analysis-understandable

197. The jurisdictional statement filed by Sanchez's counsel mentions at two points the impact of civil commitment on basic constitutional rights (Appellant's Jurisdictional Statement, Sanchez v. New Mexico, 396 U.S. 276 (1969), at 4, 9-10), once listing some of the rights in summarizing the arguments briefed in the state court and once again in summarizing his argument at the end. At neither point does he fully develop his arguments. The scantiness of the argument can in part be attributed to the length limits on jurisdictional statements, but, whatever the reason, the Court did not have before it the full arguments that can be made.

198. 419 F.2d 617 (D.C. Cir. 1969).

199. See text accompanying notes $143-46$ supra.

200. 419 F.2d at 623 .

201. 419 F.2d at 623 n.17. 
since the court had previously found a statutory basis for requiring the search for alternatives and had no need to develop a constitutional foundation.

A three-judge federal district court in Pennsylvania also appears to have concluded that the search for alternatives is constitutionally required. In Dixon v. Attorney General, ${ }^{202}$ Circuit Judge Biggs found unconstitutional Pennsylvania's procedure for committing persons to mental hospitals after they had served prison sentences. After a brief discussion of the constitutional infirmities, the court entered an order, with the consent of the parties, that not merely provided for elaborate procedural protections for those facing commitment, but also required the hospital involved to explore alternatives before commitment. It further enjoined courts from committing an ill person except upon "a specific finding based on a preponderance of the evidence that placement at [the] Hospital is necessary." Whether this part of the consent order is supported by the court's finding that the Pennsylvania statute was unconstitutional is unclear. Unlike many cases involving consent decrees, the court here did make its own findings of unconstitutionality. ${ }^{204}$ On the other hand, though the failure of the state courts to determine the need for inpatient hospitalization was one of the inadequacies alleged in the complaint, ${ }^{205}$ the issue is not one of those dealt with by the court in its brief discussion of the merits.

So far as I can find, no state court has been asked to decide whether a search for less restrictive alternatives to civil commitment is mandated under its own constitution. Moreover, the only state other than New Mexico asked to address the issue as a federal constitutional question has reached the same result as Sanchez even more abruptly. Counsel for an ill person in New York brought many Supreme Court decisions, as well as Covington, to a trial court's attention. The trial court dismissed the argument in a single sentence: "Plaintiff's contention as to alternative courses of treatment ... does not state a constitutional claim (cf. Lake v. Cameron .. .)."200

202. 325 F. Supp. 966 (M.D. Pa. 1971).

203. 325 F. Supp. at 974 .

204. 325 F. Supp. at $972-73$.

205. See 325 F. Supp. at 968.

206. Fhagen v. Miller, 65 Misc. 2d 163, 173, 317 N.Y.S.2d 128, 139 (Sup. Ct. 1970), aff. as modified per curiam, 36 App. Div. 2d 926, 321 N.Y.S.2d 61 (1971), affd., 29 N.Y.2d 348, 278 N.E.2d 615, 328 N.Y.S.2d 393 (1972). 
3. Civil Commitment Involves So Severe an Infringement of

Fundamental Liberties that Alternatives Must Be Explored

In 1960, in Shelton the Supreme Court stated that whenever "fundamental personal liberties may be stifled" by a state regulation, states must use "Iess drastic means for achieving the same basic purposes." ${ }^{207}$ As we have seen, the Court's actions in other cases before and since have been largely consistent with this general precept. Thus, its action in the Sanchez case, dismissing out of hand an appeal contending that state courts must explore less restrictive alternatives to commitment, may rest on a judgment, however hastily formed, that civil commitment endangers no "fundamental personal liberties."

A liberty is "fundamental" in the Court's view not because of its subjective importance to the individual, but rather because it finds a place in the provisions of the Constitution or in the scheme of social organization the Constitution is believed to have sought to protect. ${ }^{208}$ In a recent case, for example, the Supreme Court invalidated state laws conditioning welfare benefits on residence within the state for a substantial period on the ground that the requirements intruded excessively and, for some alleged functions, unnecessarily on an applicant's constitutionally based right to travel;:209 yet in another welfare case, in which the recipients stressed as the injured interest solely their need for food and basic necessities, the Court refused to listen to arguments that the state regulation was unnecessarily broad..$^{210}$ Although most people, if forced to choose, would rather eat than travel, the Constitution, according to the Court, protects travel but is neutral toward sustenance. Some state courts

207. 364 US. at 488. See more extensive quotation in note 181 supra. See also similar phrasing in NAACP v. Alabama, 377 U.S. 288, 307.08 (1964).

208. Dandridge v. Williams, 397 U.S. 471, 484-86 (1970); Harper v. Virginia Bd. of Elections, 383 U.S. 663, 670 (1966). See Kauper, Penumbras, Peripheries, Emanations, Things Fundamental and Things Forgotten: The Griswold Case, 64 Mich. L. REv. 235, 236-40 (1965); Michelman, Foreword: On Protecting the Poor Through the Fourteenth Amendment, 83 HARv. L. REv. 7, 24 (1969).

209. Shapiro v. Thompson, 394 U.S. 618 (1969). The case was based on the equal protection clause coupled, somewhat inartfully, with the right to travel. The District of Columbia argued that its one-year residency requirement served as a safeguard against fraudulent receipt of benefits from two states at once. The Court found that "less drastic means" were "available"-that is, simply sending a letter of inquiry to the state from which the applicant had moved. 394 U.S. at 637.

210. Dandridge v. Williams, 397 U.S. 471, 484, 486 (1970). The Court explicitly rejected the applicability of the less restrictive alternative principle announced in the Shelton case (397 U.S. at 484), even though there were persuasive arguments raised in dissent by Justice Marshall that the family grant limits at issue were unnecessarily broad for the state's purposes. 397 U.S. at 526-27. 
have taken much the same position, requiring the use of alternatives when constitutionally protected liberties were at stake but not when the citizen was asserting no more than that a government regulation - for example, of marijuana-was broader or harsher than necessary. ${ }^{211}$

Accordingly, though judicial review of the necessity for governmental actions might be wise and justifiable in a far wider range of cases, $^{212}$ the question under current law for purposes of this article is whether civil commitment involves infringements of constitution-

211. See Commonwealth v. Leis, 355 Mass. 189, 195-96, 243 N.E.2d 898, 904 (1969) (recognizing principle of least restrictive alternative in first amendment cases, but rejecting its application in cases attacking constitutionality of marijuana laws).

212. Under the broadest possible standard, courts would review the availability of less restrictive alternatives for all governmental regulations conceivably on the theory that an unnecessarily oppressive regulation deprives the person regulated of his liberty (to act inconsistently with the regulation) without due process of law. This position is not wholly devoid of merit. Early in this century after all, the Supreme Court did adopt essentially this position under the due process clause with regard to economic regulation; and, if the Court had consistently examined the question of necessity with as much sympathy for the legislatures' concerns for protecting workers and consumers as it displayed for industry's freedom to act as it pleased, the doctrine might have served a legitimate and valuable function. It is certainly desirable that the economy not be clogged by unnecessary regulation. See Struve, supra note 183. The courts, however, are unlikely to begin searching for alternatives for all regulation-and such a burden on courts may well make little sense as an efficient allocation of responsibilities between courts, on the one hand, and legislatures and administrative agencies on the other. Given the other matters for which a judiciary is necessary, it would be an unwise use of judicial resources for courts to review whether a stoplight was necessary at the corner of Elm and Main or whether it is necessary to ban campfires in Central Park.

But is the Supreme Court's apparent requirement that less restrictive alternatives be used only when regulations imperil "fundamental personal liberties" (or other constitutionally protected liberties) the only place a line might be drawn short of a position that courts review the necessity for all regulations? I can suggest two middle grounds, each of which might lead to a close review of commitment of the mentally ill. The first, borrowed from the approach suggested in the often-quoted, rather shopworn Carolene Products footnote (United States v. Carolene Prods. Co., 304 U.S. 144, 152.53 n.4 (1938)) would be to require an examination of alternatives for regulations especinlly affecting "discrete and insular minorities"-minorities that have unequal access either to the polls or to the legislature's ear and thus can find only through the courts any protection from unnecessary regulation. Those confined in mental hospitals stand in this position.

A second standard that might be coupled with the first is even more imprecise. It wonld lead to a judicial search for alternatives whenever the threatened governmental regulation has important and substantial impact upon the lives of those affected. $C f$. Wilke \& Holzheiser, Inc. v. Department of Alcoholic Beverage Control, 65 Cal. 2d 340, 363 n.10, 420 P.2d 735, 744 n.10, 55 Cal. Rptr. 23, 32 n.10 (1966) ('[The Shelton] principle has ... no application to a purely economic regulation, impinging in no significant way upon the dignity or freedom of the individual'). Admittedly fluid, a standard essentially this fluid has guided the Supreme Court in determining under the due process clause how elaborate a hearing or other procedural protection the government must provide before taking various kinds of actions (see Goldberg v. Kelly, 397 U.S. 254, 263 (1970)) and has been suggested by a minority of Justices as a guide for applying more rigorous review in cases decided under the equal protection clause (Dandridge v. Williams, 397 U.S. 471, 520-21 (1970) (Marshall, J., dissenting)). 
ally protected liberties under either state constitutions or the federal constitution.

Nearly forty state constitutions contain provisions establishing the right of their citizens to life, liberty, and the pursuit of happiness. ${ }^{213}$ Some state courts have read this language expansively ${ }^{214}$ and viewed it as a substantive limit on the legislature's powers. ${ }^{215}$ The Supreme Court of Hawaii has, for example, defined the bounds of protected freedom in broad terms-" the right of men to walk in the field, in the country or on the streets of a city, to stand under open sky in a public park and enjoy the fresh air, ... to visit a friend in his home and enjoy an evening together. ${ }^{216}$ Wielding this language, it has stricken more than one state law restricting freedom of movement when it found the state had gone "further than necessary" to protect a legitimate interest. ${ }^{217}$ Of course, all the aspects of freedom for which the Hawaii court expresses concern-walking in a park or visiting a friend-are constricted or eliminated for persons who are civilly committed, and, if the Hawaii court is to be consistent with its earlier decisions, it should require the use of less restrictive alternatives to civil commitment whenever they will serve the state's legitimate needs. Many state appellate courts have indeed acknowledged the massive constriction of freedom that civil commitment entails. ${ }^{218}$ Lawyers would be well advised to scour the terms of their own often little-explored state constitutions as well as the decisions of their courts to see whether similarly expansive language lies hidden.

213. The language is typically found in the opening articles of the state's constitution. E.g., ARK. Const. art. 2, § 2; CAL. Const. art. 1, § 1; Fla. Const. art. I, § 2; GA. Const. Preamble; IIL. Const. art. 1, § I; KAN. Const. Bill of Rights, § I; N.D. ConsT. art. I, § I; PA. Const. art. I, § I; VA. Const. art I, § I; WIs. Const. art. I, § 1.

214. See, e.g., State v. Cromwell, 72 N.D. 565, 9 N.W.2d 914 (1943); Pavesich v. New England Mut. Life Ins. Co., 122 Ga. 190, 195, 50 S.E. 68, 70 (1904); Young v. Commonwealth, 101 Va. 853, 45 S.E. 327 (1903).

215. See, e.g., City of New Orleans v. Miller, 142 La. 163, 76 S. 596 (1917) (invalidating a city ordinance restricting the living area of black prostitutes as an infringement of their "essential right to live in the community").

216. State v. Shigematsu, - Hawaii -, 483 P.2d 997, 1001 (1971). The relevant provision of the Hawaii constitution is article $\mathrm{I}$, $\& 2$.

217. State v. Shigematsu, - Hawaii at - $483 \mathrm{P} .2 \mathrm{~d}$ at $100 \mathrm{l}$ (invalidating a statute declaring it a crime to be present "in a room ... difficult of access ... to police officers where gambling instruments [are] exhibited or exposed to view'); State v. Abellano, 50 Hawaii 384, 395, 441 P.2d 333, 340 (1968) (holding unconstitutional a statute making it a crime to be present at a cockfight (concurring opinion)). See also City of Seattle v. Drew, 70 Wash. 2d 405, 408, 423 P.2d 522, 525 (1967).

218. See, e.g., State ex rel. Bles v. Merrick, 2 Ohio St. 2d 13, 16, 205 N.E.2d 924, 926 (1965); In re Allison, 336 Mich. 316, 58 N.E.2d 90 (1953). 
The place of freedom from confinement is more uncertain under the United States Constitution than under such state constitutions. Does civil commitment involve intrusions on fundamental personal liberties protected under the federal constitution? Or does it merely impinge on interests that, however important they may tower for the individual, are, like hunger, not a matter of federal constitutional concern? Judge Bazelon in the Covington case felt justified in requiring exploration of less restrictive alternatives to commitment by pointing to the "extraordinary deprivation of liberty" it involves. ${ }^{219}$ It is indeed hard to accept that there can be any "fundamental personal liberty," to use Shelton's term, ${ }^{220}$ more fundamental than personal liberty itself and personal liberty is, of course, what is at risk in its most literal sense for the mentally ill. Yet, except for the cruel and unusual punishment clause and the excessive bail clause, the federal constitution places no explicit substantive limits on "extraordinary deprivations of liberty," providing by its terms only procedural protections. Judge Bazelon, however swift his reasoning, was nevertheless correct.

Of rights protected under the federal constitution, those most obviously constricted by commitment are a person's right to travel and his right of free association. The Supreme Court has repeatedly recognized, under a variety of constitutional rubrics, ${ }^{221}$ the right of Americans to move about from place to place within the nation or the world. "Freedom of movement," the Court has justly found, "is basic to our scheme of values."222 Civil commitment does not merely penalize movement, as do welfare residency requirements, ${ }^{223}$ or somewhat curtail it, as do passport limitations. ${ }^{224}$ It eradicates it altogether. In the same manner, freedom of association-the right of "the people to gather in public places for social or political purposes," 225 their right to associate with people of their choice, protected

219. 419 F.2d at 623 .

220. 364 U.S. at 488 .

221. Justice Harlan in his dissent in Shapiro v. Thompson, 394 U.S. 618, 665-71 (1969), surveyed the variety of constitutional provisions under which various Justices at various times have found a basis for a right to travel among the states. These include the commerce clause, the privileges and immunities clause in article IV, the privileges and immunities clause in the fourteenth amendment, and the due process clause of the fifth amendment. The right to travel internationally was found to flow from the due process clause of the fifth amendment. Kent v. Dulles, 357 U.S. 116, 125 (1958); Aptheker v. Secretary of State, 378 U.S. 500, 505 (1964).

222. Kent v. Dulles, 357 U.S. 116, 126 (1958).

223. Shapiro v. Thompson, 394 U.S. 618 (1969). Another invalidated "penalty" was a tax on crossing the state line. Crandall v. Nevada, 73 U.S. (6 Wall.) 35 (1867).

224. Aptheker v. Secretary of State, 378 U.S. 500 (1964).

225. Coates v. City of Cincinnati, 402 U.S. 611 (1971). 
under the first amendment-is drastically circumscribed. ${ }^{226}$ Suddenly the sphere within which the ill person may travel or associate shrinks from the globe, or the state, or the city down to a day room of forty, or sixty, or two hundred others whom he did not choose to know.

Justice Douglas has correctly said of the rights of travel and association that they "make all other rights meaningful-knowing, studying, arguing, exploring, conversing, observing and even thinking." ${ }^{227}$ His points apply as fully when these rights are viewed in their most commonplace forms. The right to travel is typically disputed in the context of impediments to travel across state or national borders. The person committed to a hospital is, of course, precluded from such travel and that barrier alone would justify applying the principle of the least restrictive alternative to civil commitment. But it is important to recognize that the travel most valued by the bulk of civilly committed persons-not travel to Moscow or Cuba, but travel across the street or through the park-is also protected by the federal right to travel. In a federal system, travel across state lines does require special protection, but the reasoning in cases establishing protection for international travel under the due process clause applies as fully to travel within a state or city as it does to travel overseas. The Court in the principal cases dealing with international travel has not attached special significance to the fact that the travel was international but rather to the fact of travel itself: "Freedom of movement across frontiers in either direction, and inside frontiers as well, was a part of our heritage." 228

In recent months, in striking down on grounds of vagueness an ordinance aimed at "common night walkers," a unanimous Court through Justice Douglas sang hymns of praise to "wandering and strolling." "228 These amenities of American life, though not mentioned in the Constitution, "have been in part responsible for giving our people [their] feeling of independence and self-confidence" and "have encouraged lives of high spirits rather than hushed, suffocating

226. One of the first cases to articulate a separate right of association under the first amendment was NAACP v. Alabama, 357 U..S. 449 (1958). Several cases, many of them also growing out of the southern states' crusades against civil rights organizations, a few out of comparable attacks on the Communist Party, have been decided since. See, e.g., Shelton v. Tucker, 364 U.S. 479 (1960) (civil rights); NAACP v. Button, 371 U.S. 415 (1963) (civil rights); Gibson v. Florida Legislative Investigation Comm., 372 U.S. 539 (1963) (civil rights and communists); United States v. Robel, 389 U.S. 258 (1967) (communists).

227. Aptheker v. Secretary of State, 378 U.S. 500, 520 (concurring opinion).

228. Kent v. Dulles, 357 U.S. 116, 126 (1958). Accord, Aptheker v. Secretary of State, 378 U.S. 500, 505-06 (1964). See also Zemel v. Rusk, 381 U.S. 1, 15-16 (1965).

229. Papachristou v. City of Jacksonville, 405 U.S. 156, 163-64 (1972). 
silence." ${ }^{230}$ Our heritage was probably less solicitous of the traveler than the Court suggests, ${ }^{231}$ but, whatever its lineage, the right to travel and free movement rests today on reasoning that applies at least as securely to the eccentric's movements within his community as to Aptheker's voyages across the sea.

If lawyers characterize the right to travel as providing some measure of protection for all movement, ${ }^{232}$ courts may recoil from relying on the right as a basis for requiring close review of civil commitments. Whether courts will find that freedom of association provides a more manageable analytical framework is unclear. Based on the first amendment, freedom of association typically evokes grandiose images of protection for membership and participation in political organizations. ${ }^{233}$ Civil commitment curtails such activities but, like curtailment of travel, the more painful losses for most committed persons are probably the more mundane aspects of human association - the right to keep company with people of one's choice. This, too, the Supreme Court's decisions make clear, the right of association protects-not merely the right to join a union or a political party but the right to stand on a street corner and chew the fat with old friends. Last Term, for example, the Court struck down, as a violation of the federal constitutional rights of association and assembly, a city ordinance that prohibited "three or more persons to assemble" on a sidewalk and "conduct themselves in a manner annoying to [others]." ${ }^{234}$ Though the case involved youthful political demonstrators, Justice Stewart, speaking for the Court, struck down the statute as unconstitutional on its face and based his decision on "the right of the people to gather in public places for social or political purposes." 235

In short, the curtailment of the rights of travel and association, given the broadened view of those rights, is not a mere incidental side effect of commitment; curtailment of movement and social in-

230. Papachristou v. City of Jacksonville, 405 U.S. at 164.

23I. The Court's recall of history is, as often, shaped by the result it was secking. At least as to some classes of people, the poor especially, exercising the right to travel in the eighteenth century involved the risk of being shipped back forcibly to one's place of origin. D. Rotrman, supra note 11 , at 20-25.

232. See, e.g., the expansive view of the right to travel taken by Amsterdam, Federal Constitutional Restrictions on the Punishment of Crimes of Status, Crimes of General Obnoxiousness, Crimes of Displeasing Police Officers, and the Like, 3 CruM. L. BuLL. 205, 213-15 (1967).

233. See the cases cited in note 226 supra. See also Williams v. Rhodes, 393 U.S. 23 (1968) (protection of political party participation).

234. See Coates v. City of Cincinnati, 402 U.S. 611, 611 (1971).

235. Coates v. City of Cincinnati, 402 U.S. at 615. 
tercourse is often in fact one of the central purposes of commitment. And that is not the end of the commitment's curtailment of an ill person's liberties. His rights peaceably to assemble, ${ }^{236}$ to communicate and receive communications from others, ${ }^{237}$ to exercise his religious belief through ceremonies of his choice, ${ }^{238}$ and to enjoy his privacy in the company of his spouse, ${ }^{239}$ or even someone not his spouse, ${ }^{240}$ are all but totally ended.

I have sensed, however, in writing the above paragraphs that the fact that the curtailment of liberty by civil commitment is so total and that civil-commitment legislation does not by its terms refer to "travel," to "association," or to sexual relations with one's spouse may, by some ironic and inappropriate process, appear to make such rights irrelevant to an analysis of the issues surrounding civil commitment. Much the same problem is posed in discussing the seriousness of a policeman's killing of a fleeing suspect in terms of its impact on the suspect's right to trial by jury. Perhaps an unconscious desire to deny the impact of confinement (or killing) leads us to refuse to think seriously about the loss of freedom involved. ${ }^{241}$

In any event, the case for holding that civil commitment encroaches on fundamental rights rests not alone on its impairment of such rights as travel and association. Though their impairment is the strongest source of support, the Supreme Court has also indicated that physical confinement in itself, without reference to other rights, warrants special scrutiny under the Constitution.

Each of the cases that the Supreme Court has decided touching

236. The first amendment by its terms protects "the right of the people peaceably to assemble." For an example of a Supreme Court decision resting on the right of assembly, see De Jonge v. Oregon, 299 U.S. 353 (1937).

237. Regarding the right to receive communications from others, see Lamont $v$. Postmaster General, 381 U.S. 301 (1965).

238. See Sherbert v. Verner, 374 U.S. 398 (1963); West Virginia State Bd. of Educ. v. Barnette, 319 U.S. 624 (1943). See also Winters v. Miller, 446 F.2d 65 (2d Cir. 1971) (mental patient who was a Christian Scientist could not be compelled to take tranquilizing medication).

239. This right is protected under "penumbras" of specific guarantees of the Bill of Rights, Griswold v. Connecticut, 381 U.S. 479 (1965).

240. See Eisenstadt v. Baird, 40 U.S.L.W. 4303 (U.S. March 22, 1972) (holding unconstitutional under the equal protection clause a statute making it a felony to distribute contraceptives to unmarried, but not to married, persons. In reaching this decision the Court said, "If the right to privacy means anything, it is the right of the individual, married or single, to be free from unwarranted government intrusions into matters so fundamentally affecting a person as the decision whether to bear or beget a child." 40 U.S.L.W. at 4308 (emphasis original)).

241. Once, while working at St. Elizabeth's Hospital in Washington, D.C., I raised the issue of conjugal visits for the patients in a building housing men found not guilty by reason of insanity. A psychiatrist responded that such visits were unimportant, for the men had more important problems to worry about. 
on aspects of civil commitment makes clear the Court's recognition that it is dealing with particularly sensitive areas of regulation. For example, in upholding Minnesota's commitment of sexual psychopaths, the Court acknowledged "the special importance of maintaining the basic interests of liberty in a class of cases where the law ... may be open to serious abuses in administration." 242 In another decision, the Court mentioned, without elaboration, the impact of commitment on "fundamental rights." 243 In yet another rendered in the past few months the Court emphasized that commitment involved "a massive curtailment of freedom." 244 These decisions provide strong indications of the Court's concern for freedom from physical confinement. ${ }^{245}$

In three other decisions dealing with somewhat different forms of confinement, the Court has either explicitly indicated that it was subjecting a law or procedure to close scrutiny because of its impact on physical freedoms or reached a result that cannot be explained except in terms of such close scrutiny having been given. In 1944, in Korematsu $v$. United States, ${ }^{246}$ the Court upheld the military order excluding persons of Japanese ancestry from parts of the West Coast -effectively barring many from their homes. The most remembered, pernicious aspect of the ban was its ethnic basis, but the Court expressed no less concern for its curtailment of free movement. "Compulsory exclusion of large groups of citizens from their homes, except under circumstances of direct emergency and peril, is inconsistent with our basic governmental institutions." 247 The Court upheld the exclusion, but only because of the apprehension by military authorities of the "gravest imminent danger to public safety"248 during time of war.

242. Minnesota ex rel. Pearson v. Probate Court, 309 U.S. 270, 276-77 (1910).

243. Baxstrom v. Herold, 383 U.S. 107, 113 (1966) (holding unconstitutional as a denial of equal protection New York's system of transferring persons completing prison terms to mental hospitals upon completion of their sentence.) See also Lynch v. Over. holser, 369 U.S. 705, 711 (1962).

244. Humphrey v. Cady, 40 U.S.L.W. 4324, 4325 (U.S. March 22, 1972) (remanding for a full hearing a case challenging the constitutionality of Wisconsin Sex Crimes Act that permitted holding a person beyond maximum term of sentence when found dangerous as a sexual deviant; the Court found the extended commitment essentially similar in impact to commitment under the state's civil commitment code).

245. As this article went to press, the Court gave yet another indication of its concern by holding that states may not commit a person indefinitely upon a finding of incompetence to stand trial. Jackson v. Indiana, 40 U.S.L.W. 4615 (U.S. June 7, 1972). 246. 323 U.S. 214 (1944). Compare City of New Orleans v. Miller, 142 La. 163, 76 S. 596 (1917), discussed in note 215 supra.

247. 323 U.S. at $219-20$.

248. 323 U.S. at 218. 
Over twenty years later, the Court dealt with a second gross restriction on free movement. In 1967, in In re Gault, ${ }^{249}$ the Court held that states must accord broad procedural protections to those facing commitment to juvenile institutions. Without alluding to abridgment of rights of association or travel, it required these protections in substantial part because a youth adjudged a juvenile "may be restrained of liberty for years."250 Indeed, Justice Fortas, writing for the Court, expressed chagrin that the juvenile judge in the case before them had not explored alternatives to commitment, ${ }^{251}$ and even extended a mild hint (so mild that the other concurring Justices might hardly have noticed in an opinion stretching fifty-seven pages) that a constitutional obligation might exist to perform the examination. ${ }^{252}$ Three years later, the Court extended its holding in Gault to require proof of the juvenile's guilt beyond a reasonable doubt, again because of the "loss of . . . liberty" that was at risk. ${ }^{253}$

The third and most recent decision, Williams $v$. Illinois, ${ }^{254}$ arose in the context of a criminal, rather than civil, commitment, but was described by Justice Harlan in concurrence as "unquestionably show[ing] that this court will squint hard at any legislation that deprives an individual of his liberty-his right to remain free."255 At first glance, a reader may perceive little extraordinary squinting. Williams involved an attack on a practice common in many states under which misdemeanants unable to pay fines work them off in jail at the rate of a few dollars each day. Williams had been sentenced to a year's imprisonment coupled with a fine. Unable to pay at the end of his sentence, he faced an extra 101 days in jail. Speaking for seven Justices, Chief Justice Burger held that the system of working off fines impermissibly discriminated on the basis of wealth and that the equal protection clause requires that the statutory

249. 387 U.S. 1 (1967).

250. 387 U.S. at 27.

251. 387 U.S. at 28: "Under traditional notions, one would assume that in a case like that of Gerald Gault, where the juvenile appears to have a home, a working mother and father, the juvenile judge would have made a careful inquiry and judgment as to the possibility that the boy could be disciplined and dealt with at home."

252. 387 U.S. at 28 n.41: "With respect to the possible duty of a trial court to explore alternatives to involuntary commitment in a civil proceeding, cf., Lake $v$. Cameron ...., which arose under statutes relating to the treatment of the mentally ill."

253. In re Winship, 397 U.S. 358, 366, 368 (1970).

254. 399 U.S. 235 (1970).

255. 399 U.S. at 263. The significance of Williams in this regard has also been recognized by a recent law review article. Wexler, Scoville, et al., supra note 140, at $142-43$. 
ceiling placed on imprisonment for any substantive offense be the same for all defendants without regard to economic class. ${ }^{260}$

Justice Harlan concurred in the result. He pointed out, as he had in other cases involving de facto discrimination between rich and poor, ${ }^{267}$ that analysis under the equal protection clause masks the real concerns troubling the Court. It is true that the fine structure works differing hardships on rich and poor, but so also do fees for government publications, sales taxes, and turnpike tolls, none of which are likely to be held unconstitutional. What is critical in the cases in which the Court has overturned such de facto discriminations is the importance under the Constitution of the item or privilege that the poor cannot afford. ${ }^{558}$ Prior to Williams the inaccessible items had been trial transcripts or other tools of criminal defense. ${ }^{260}$ In Williams for the first time it was the right to physical freedom itself. 260

Whether the Court will recognize or evade the implications of its apparent concern for freedom from confinement is another question, for the Court has by no means always "squint[ed] hard at any legislation that deprives an individual of his liberty." In 1971, for example, Justice Harlan wrote a decision in one of the death penalty cases that, though it dealt with procedural rather than substantive rules, indicated a distressing insensitivity to the very interests he had sought to protect in Williams. Speaking for the Court he held that a state need not employ a two-stage trial process that separates the evidence the jury hears for its decision on guilt from the evidence it hears for its decision on the sentence, even though such a bifurcation could fully serve the state's legitimate interests and more fully protect against the execution of innocent persons. ${ }^{201} \mathrm{~A}$ lesser alterna-

256. 399 U.S. at $240-41$.

257. See Griffin v. Mlinois, 351 U.S. 12, 29, $34-36$ (1956) (Harlan, J., dissenting); Douglas v. California, 372 U.S. 353, 360, 361-63 (1963) (Harlan, J., dissenting).

258. See Professor Michelman's compelling defense of Justice Harlan's rejection of the majority's equal protection analysis in these cases. Michelman, supra note 208, at 36. 259. See cases cited in note 257 supra.

260. The Williams decision is also important because the Court seemed clearly to have been influenced by the availability to Illinois of alternative means of serving its goals. Though it did not rest its opinion on this ground, the Court devoted a paragraph to the "numerous alternatives," such as installment payment plans, that might permit the state to satisfy its claim against the defendant without having to jail him. 399 U.S. at 244-45. See also Tate v. Short, 401 U.S. 395, 399-400 (1971).

261. McGautha v. California, 402 U.S. 183, 208-22 (1971). See also Justice Douglas's dissent, 402 U.S. at 226-48. The unfortunate result in McGautha was foreshadowed in another unfortunate opinion of Justice Harlan in Spencer v. Texas, 385 U.S. 554 (1967). There the Court upheld Texas's equally meritless system of trying defendants under its habitual offender statute by including in the trial on the merits of a current charge the evidence of prior convictions necessary to prove him a repenter. 
tive was not required even though state-inflicted death-the ultimate destroyer of rights-was at issue.

Even more indicative of inconstancy in looking askance at legislation curtailing physical liberty is the Supreme Court's attitude toward the dozens of criminal convictions that come before it each year. Although the Court has acknowledged that its concern for the procedural protection of the criminal defendant derives from the freedom that is imperiled, ${ }^{262}$ it has never required-and is unlikely ever to require-case-by-case inquiries into the suitability of community-based treatment for every person convicted of a crime. ${ }^{263}$

The frequent insensitivity of American courts to the consequences of imprisonment is no less tragic than their insensitivity to commitment of the mentally ill, but there is at least analytically a significant difference between criminal and civil confinement-not a difference in the degree of the loss of freedom, but rather in the purposes for confinement and their susceptibility to review for alternatives. A principal historical function of the criminal sanction, apparently accepted by the Supreme Court, ${ }^{204}$ is retribution. Not so for civil commitment. ${ }^{265}$ Civil commitment may in many individual cases

262. See, e.g., Speiser v. Ranđall, 357 U.S. 513, 525-26 (1958); In re Winship, 397 U.S. 358 (1970). In holding that juveniles must be found guilty beyond a reasonable doubt, the Court in Winship first found that adults accused of crime had to be so found. The Court said: "The requirement of proof beyond doubt has this vital role in our criminal procedure for cogent reason. The accused during a criminal prosecution has at stake interests of immense importance, both because of the possibility that he may lose his liberty upon conviction and because of the certainty that he would be stigmatized by the conviction." 397 U.S. at 363 .

263. In Williams, for example, the Court explicitly assumed as beyond question that the state could consistently with the constitution have prescribed a flat jail term for rich and poor alike of one year and 101 days. 399 U.S. at 241.

264. An acceptance of retribution as a permissible goal of criminal statutes is implicit in the Supreme Court's decision invalidating an Illinois statute that permitted the prosecution to challenge for cause veniremen who indicated scruples about imposing the death penalty. Witherspoon v. Illinois, 391 U.S. 510, 519 (1968) (" $[A]$ jury that must choose between life imprisonment and capital punishment can do little more-and must do nothing less-than express the conscience of the community ...."). See also McGautha v. California, 402 U.S. 183, $203-08$ (1971) (rejecting arguments that standards must be given juries in imposing the death sentence in part on the ground that too many elusive factors, including some that relate solely to retribution, are involved). Cf. Powell v. Texas, 392 U.S. 514, 532 (1968) (approving Texas statute forbidding public drunkenness on the ground that it did not impose a sanction on a mere status, but rather on public behavior that, among other attributes, "offends the moral and esthetic sensibilities of a large segment of the community').

265. Civil commitment also differs from penal commitment in another way; penal sanctions are often imposed to scare the defendant and others into refraining from certain conduct in the future. In terms of the principle of least restrictive alternatives, however, it is unclear whether criminal courts would find any greater difficulty in assessing whether an alternative to prison will serve the state's deterrent purposes than they would in assessing whether alternatives will serve the state's rehabilitation interests. 
be motivated by a desire to punish the ill person for causing the rest of us discomfort, ${ }^{266}$ but I have never seen a judicial opinion or commitment statute recognizing punishment as a function of commitment. Thus, in criminal cases, if a state legislature has imposed a mandatory minimum jail term, state courts can do little but defer to the legislature's essentially political judgment about the length of punishment needed to satisfy society's need for revenge. ${ }^{207}$ When legislatures have imposed no minimum, state judges could be required to explore whether the community's need for retribution can be satisfied without incarceration-I would be glad to see them compelled to do so ${ }^{268}$ - but a judge's conclusions would at least be most difficult for another court to review. ${ }^{260}$

Even if courts distinguished criminal from civil confinement, a holding that commitment of the ill requires scrutiny of lesser alternatives might still carry broad implications. Recognizing the fundamental rights impaired by commitment should all but answer the question of the right to counsel and other procedural protections in commitment proceedings-questions that, somewhat surprisingly, have not been addressed by the Supreme Court. 270 Moreover, several forms of noncriminal incarceration other than that of the mentally ill might be swept within the reasoning of any case requiring consideration of alternatives of civil commitment. Confinement of the

266. See text accompanying notes 57-59 supra.

267. But see People v. Anderson, - Cal. 3d -, 493 P.2d 880, 895.97, 100 Cal. Rptr. 152, 167-69 (1972) cert. denied, 40 U.S.L.W. 3576 (U.S. June 7, 1972) (California supreme court found the death penalty in violation of the state constitution's cruel and unusual punishment clause. In reaching its decision, the court found that the death penalty was more onerous than necessary to serve society's need for retribution.).

268. For a study of the use of criminal sanctions at its most absurd-the criminal punishment of alcoholics for public drunkenness-see R. NLAMER, Two Mution UNNeGessary ARrests: Removing a Soctal Concern from the Criminal. System (1971).

269. Former Justice Goldberg and Professor Alan Dershowitz have recently suggested that a criminal punishment should be held cruel and unusual unless it serves "some other end besides retribution more effectively than any other less severe penalty" -and argue for applying the least restrictive alternative principle to hold the death penalty unconstitutional. Goldberg \& Dershowitz, Declaring the Death Penalty Unconstitutional, 83 HARV. L. REv. 1773, 1797 (1970). I fear that, despite their arguments and despite the fact that the Supreme Court of California seems to have accepted them in large part (see note 267 supra), the Supreme Court of the United States will hold that the eighth amendment permits criminal punishments even if they are intended to serve (and in fact serve) nothing other than a retributive function, so long as the particular form of punishment inflicted is not in itself or in relation to the offense found particularly uncivilized or inhumane. In any event, the constitutionality of the death penalty under the eighth amendment is pending before the Court now in Furman v. Georgia, No. 69-5003 (197I Term). In the unlikely event that the Justices adopt the Goldberg and Dershowitz reasoning and apply it to all criminal commitments, similar examination of alternatives to civil commitment should almost certainly follow. If they reject it, civil commitment will remain distinguishable.

270. I trust Gault settles this question, but the Supreme Court itself has not an- 
tubercular, the epileptic, the defective delinquent, the retarded, ${ }^{271}$ and the juvenile delinquent ${ }^{272}$ involve the same curtailments of liberty. As to all of these, I can offer no sensible distinctions to the Court. They require no less attention than commitment of the mentally ill.

The potential reach of a holding that civil commitment involves intrusions on fundamental liberties stretches even farther. Rent controls, speed limits, zoning laws, licensing requirements, divorce laws, all curtail the freedom of individuals to live their lives as they please. Involuntary incarceration marks merely the end point of a vast continuum of government restrictions on human conduct. If incarceration differs only in degree and not in kind, the Court might fear that any intervention to protect freedom from confinement would resurrect the bogeyman of substantive due process. ${ }^{273}$ In the heyday of substantive due process, the Supreme Court, in Meyer $v$. Nebraska, ${ }^{274}$ had listed "freedom from bodily restraint" as the most fundamental of freedoms but, as Justice Black took delight in pointing out, ${ }^{275}$ had also included freedom of contract among the great rights. It is language like that in Meyer that threatens to give freedom a bad name.

Here I think the Court can draw sensible lines. It need not resist a close examination of civil commitment or other commitments for fear of rejuvenating substantive due process. Givil commitment's direct intrusion on the freedoms of travel, association, free exercise of religion, and other freedoms sufficiently distinguishes commitment from most other forms of government regulation. Courts can rely on these other rights without relying on the language of the due process clause alone. In the unlikely event that courts would wish to consider a citizen's interest in freedom from incarceration without

swered it. See Heryford v. Parker, 396 F.2d 393, 396 (10th Cir. 1968) (relying on Gault to require Wyoming to provide counsel before commitment).

271. A federal district judge in Alabama has recently ordered massive changes in the treatment facilities and programs at a state institution for the retarded. Wyatt $v$. Stickney, Civil Action No. 3195-N (M.D. Ala.), Order of April 13, 1972, implementing 325 F. Supp. 781 (M.D. Ala. 1971).

272. For a slight suggestion by the Supreme Court that inquiry into alternatives is required in juvenile commitment, see In re Gault, 381 U.S. 1, 28 n.41 (1967).

273. The Court has gone out of its way in the past three decades to avoid basing decisions on substantive due process, leading to a stretching of other constitutional rubrics. See, e.g., Griswold v. Connecticut, 381 U.S. 479 (1965); Robinson v. California, 370 U.S. 660 (1962). The growth, flourishing, and demise of substantive due process is well traced in the cases and notes in W. LOCKHART, Y. KAMISAR \& J. CHOPER, ConsTItUTHONAL LAW: CASES-COMMENTS-QUESTIONS 441-504 (1970).

274. 262 U.S. 390, 399 (1923).

275. Griswold v. Connecticut, 381 U.S. 479, 507, 516 n.7 (1965) (Black, J., dissenting). 
resting in any way on these well-developed freedoms, they can draw on thirty years of Supreme Court decisions such as Korematsu and Williams, which, without explicitly distinguishing other forms of governmental regulation, nevertheless carve out a special place for freedom from incarceration that now seems justified by judicial history, even if not by the literal language of the Constitution.

\section{Ensuring That a Meaningful Search for Alternatives Occurs}

If other jurisdictions join the District of Columbia in requiring a search for less restrictive alternatives to commitment, the experience in the District warns that such decisions alone will not ensure that a meaningful search occurs. At least three further steps must be taken: ( 1 ) an adequate professional staff must be available to perform the inquiry into alternatives; (2) the court must have the power to compel the cooperation of community facilities the staff locates; and (3) the search must occur before, rather than after, commitment.

\section{A. The Appropriate System To Ensure That Altermatives Are Examined}

In the District of Columbia, one of the few jurisdictions currently requiring its trial judges to explore alternatives in all civil commitment proceedings, most judges are simply failing to do so. The government, according to the United States Court of Appeals, bears the initial obligation to search out and assess alternatives, ${ }^{270}$ but, in the vast bulk of cases, neither the staffs of the District's public mental hospital nor any other governmental agency performs anything that can be even generously labeled a search.277 Moreover, neither the initial committing agency, the Commission on Mental Health nor the reviewing agency, a federal district court, though charged with making the final decisions regarding alternatives, receives testimony on alternatives or makes findings based on materials in the record.

Of course, the patient in the District of Columbia may have a remedy for the failure of the Commission and the court by appeal to the court of appeals, but the appellate court cannot cure the problem in the District of Columbia by simply ordering judges to

276. Lake v. Cameron, 364 F.2d 657, 662 (D.C. Cir. 1966).

277. This and the next several points about the operation of the commitment process in the District derive from telephone interviews with Robert Golten, of the District of Columbia Public Defender Service. The Public Defender Service represents nearly all persons for whom commitment is sought. 
meet their statutory obligations. It is true that many committing judges across the country seem to ignore their statutory obligations and accept an occasional reversal as the easy price to pay for swift commitment processes, ${ }^{278}$ but even the most conscientious judge or commission needs more than the traditional clash of adversarial testimony to make sensible judgments about alternatives.

As has been shown, the task of assessing alternatives to hospitalization bristles with difficulties. It demands continuing familiarity with the range and capacity of the treatment approaches available in the community as well as complex judgments about a particular patient's suitability for treatment through them. Judges and committing agencies, if unaided by staffs of their own or by advice from the hospital, are unlikely to make sensible decisions about community alternatives. In the District, the Commission on Mental Health has no staff assigned to exploring alternatives; and the public hospital is inadequately staffed to provide advice. In Ohio, where courts are also explicitly permitted to draw on community alternatives, ${ }^{279}$ the courts, at least in Cleveland, almost never do. ${ }^{280}$

If the principle of the least restrictive alternative were accepted now, most other jurisdictions would find themselves in the same unpromising position as the District and Ohio. To give the principle teeth-or even dentures-courts will need continuing professional advice about available alternatives. Generally in this country when states require judges or administrative agencies to reach complex judgments outside their normal spheres of competence, they are assisted by experts. Judges engaged in civil commitment do not decide whether a person is ill solely on the basis of their own observations or the testimony of lay witnesses. Rather, state statutes almost invariably require an examination by a physician or psychiatrist $^{281}$ and judges rely quite heavily on their advice. ${ }^{282}$

Procedures in adult felony courts and juvenile courts offer an even closer parallel. Judges in courts handling such cases generally arrive at decisions on sentencing with the aid of probation officers who

278. See, e.g., Pfrender, supra note 161 , at $150-51$ (reporting a study of 221 consecutive petitions for writs of habeas corpus filed by patients at a public hospital in Michigan. Of the 221 petitions 198 were granted, 188 for defects in the initial commitment process that the initial committing judge might have prevented or corrected.).

279. OHIo REv. Code ANN. § 5122.15 (Page 1970).

280. Telephone interview with David Strand, Legal Aid Society, Cleveland, Ohio, March 20, 1972. The Legal Aid Society has attorneys and law students working in the public hospitals in Cleveland.

281. See statutes compiled in S. Braker \& R. Rock, supra note 2, Table 3.2, at 72-79.

282. See Pfrender, supra note 161 , at 147. 
gather information and examine and assess community-based alternatives to imprisonment. ${ }^{283}$ The judge, swamped by dozens of responsibilities, can rarely keep abreast of the range and current capacity of available facilities or assemble for himself the data necessary to assess the convicted person's suitability for any of the facilities. Critics, it is true, complain about the adequacy of information that probation officers today provide to juvenile and criminal judges, but the solutions proposed generally call for an improvement in the quality of information, ${ }^{284}$ not a return to a system in which judges make decisions about probation aided only by the oral blandishments of counsel.

Given the complexity of medical judgments that may be involved in assessing community alternatives, as well as the fears and misconceptions of lay persons, including judges, about the mentally ill, a functionally comparable system for exploring alternatives seems even more desirable in civil commitment proceedings than in criminal or juvenile cases. If states will not establish such systems voluntarily, the Constitution can provide a basis for requiring their development. The obligation to establish such a system derives from the principle of the least restrictive alternative: the Constitution, we have concluded, imposes an obligation on states to explore less restrictive alternatives before committing an ill person; merely relying on the parties to bring information about alternatives to the court's attention will not assure the necessary exploration in most cases; therefore, in order to protect the constitutional right-to assure it is not a right foundering for want of a remedy-the state must establish a system that will adequately guarantee that the exploration occurs.

Many precedents exist for requiring the development of adequate systems to protect constitutional rights. For example, the Supreme Court compelled New York and sixteen other states to replace a procedure in criminal trials that left the determination of the voluntariness of a confession primarily to the jury with a new procedure

283. For a description of the information-gathering process of probation officers in criminal courts, see R. Dawson, Sentencing: The Deciston as to TxpE, LENGTH, AND CONDTTIONS OF SENTENCE 11-55 (1969).

284. See, e.g., Tappan \& Nicolle, An Appraisal of Juvenile Courts, in P. Dressler, REAdings in Criminology and Penology 466 (1964):

The value of probation as a treatment measure is generally accepted. Nonetheless, its ill-advised use has sometimes made it a synonym for leniency. The cardinal elements of sound probation are careful selection of offenders and adequate supervision of probationers. Too often, however, untrained and overburdened staffs have made a travesty of the selection and supervision processes. 
that required the judge to make a preliminary finding of voluntariness and exclude confessions he found involuntary. ${ }^{285}$ Although New York had long recognized an obligation to protect the defendant's constitutional right not to incriminate himself, the method it had chosen inadequately protected that right and therefore required replacement. Similarly, the Court has held that states must assure black children the equal protection of the laws not merely by schools that are separate but equal but, beyond this, by integrating the children in the schools. ${ }^{286}$ Although not all Justices have agreed that federal courts have a responsibility to prescribe remedies for the vindication of federal constitutional rights, ${ }^{287}$ a majority of the Court nonetheless recognizes that the function of courts is not merely to articulate such rights but also to ensure that they are protected. (To be sure, what is suggested here pushes one step farther than the Court has trod thus far: it asks courts to force the creation of effective systems for exploring alternatives without waiting to observe whether merely articulating the right will lead to an adequate search. The District of Columbia's experience and a moment's reflection should lead courts to act forcefully from the outset.)

Long-standing precepts of procedural due process add further support. The Supreme Court has held that, before government takes action against an individual bearing potentially serious consequences for him, procedural due process requires that he be afforded a hearing, the format, scope, and participants of which will vary with the nature of the interests at risk and the questions to be answered. ${ }^{288}$ The demands of due process are generally considered satisfied if the state extends to the affected person a "meaningful" opportunity to be heard on each significant issue - "meaningfulness" in most cases being considered assured by providing the opportunity to appear

285. Jackson v. Denno, 378 U.S. 368 (1964).

286. Brown v. Board of Educ., 347 U.S. 483 (1954). See also United States v. Wade, 388 U.S. 218 (1967), Miranda v. Arizona, 384 U.S. 436 (1966), and Mapp v. Ohio, 367 U.S. 643 (1961), which required governments to establish more substantial protections for the constitutional rights of defendants in criminal cases.

287. For example, rejecting the exclusionary rule under the fourth amendment, Justice Harlan would have left entirely to the states the decision of the appropriate remedies to protect against unreasonable searches (see Coolidge v. New Hampshire, 403 U.S. 443, 490-91 (1971) (Harlan, J., concurring)) and Justice Black believed that unless the Constitution explicitly prescribes a remedy (as the fifth amendment does but the fourth does not), no constitutionally compelled remedies exist (see 403 U.S. at $496-500$ (Black, J., concurring and dissenting)).

288. Stanley v. Illinois, 40 U.S.L.W. 4371, 4373 (U.S. April 3, 1972); Goldberg v. Kelly, 397 U.S. 254, 262-63, 267 (1970); Cafeteria \& Restaurant Workers Union v. McElroy, 367 U.S. 886, 895 (1961). 
personally, to call witnesses in one's own behalf, and to cross-examine opposing witnesses. ${ }^{289}$ Perhaps courts would require no more than this under state and federal due process clauses with regard to the exploration of alternatives to civil commitment-that is, merely require that the allegedly ill person be given an opportunity to be heard regarding alternatives; but the Gourt has poured more into the content of "meaningfulness" when the occasion has demanded it. 290

The issue of alternatives to commitment is unlike most of the issues in dispute in cases that have provoked decisions regarding adequate procedures under the due process clause. Most decisions have wrestled with the minimum process that the state must offer to assure an airing of reasonably straightforward factual questions (Was Ms. Kelly eligible for public assistance? Are Mr. Sniadach's wages subject to garnishment?). ${ }^{291}$ In these cases merely giving the affected person an opportunity to tell his version of the story (aided, perhaps, by counsel) and interrogate the witnesses against him should provide adequate protection. By contrast, when the issue is the range of possible alternatives to commitment, affording an ill person or his counsel the opportunity to speak his piece or call his own witnesses will rarely provide a sufficient exploration and assessment. If, as seems probable, providing staff to explore alternatives is the only method of assuring a meaningful examination, then such a system should be considered constitutionally required. ${ }^{202}$ I understand, of course, that there are limits on the costs that courts can reasonably ask the public to bear in the name of due process; but, as we have seen, governments have long borne the costs of systems for exploring alternatives to penal or juvenile commitment. That fact alone seems persuasive evidence that requiring the establishment of a comparable system to explore alternatives to civil commitment would inflict no intolerable burden.

If the Constitution does require some sort of institutionalized system to ensure the examination of alternatives, it surely does not compel the adoption of any specific system-so long as the system adopted assures a reasonable likelihood that alternatives can be identified and evaluated. At least three models exist that states might be

289. Goldberg v. Kelly, 397 U.S. 254, $266-71$ (1970) (welfare benefits); Sniadach v. Family Fin. Corp., 394 U.S. 337, 339-40 (1969) (wage garnishment).

290. See Boddie v. Connecticut, 401 U.S. 371 (1971) (holding, in a rather strained use of the due process clause, that in order to provide a "meaningful" hearing to indigents seeking divorce, Connecticut must waive a requirement of a filing fec).

291. See note 289 supra.

292. Cf. Boddie v. Connecticut, 401 U.S. 371, $374-77$ (1971). 
likely to consider. None is free of problems. Like the problem of choosing alternatives to commitment, each is less satisfactory than one of the others in at least one aspect. Under the first model, to me the most attractive, the responsibility for the search would rest in the hands of trained personnel employed by the court itself. Such a staff, probably best composed primarily of social workers, would be comparable in purpose to the probation officers employed by most juvenile and criminal courts and would be attuned to the functions that the particular judge serves through commitment. A court-based staff might also be able to clothe itself with some of the awesomeness of the judge's office and bedazzle those administering local programs and agencies into cooperation. And, perhaps most important, with the staff under the direction of the judge, the likelihood seems great, given the experience in the area of probation in criminal cases, ${ }^{293}$ that he will rely upon and trust their recommendations and equally important, that he will become personally. involved in the development of new community-based programs.

One difference between criminal and civil commitment, however, does complicate the matter: the central role in civil commitment of the diagnosing psychiatrists. Psychiatrists dominate the commitment process in almost all states. Their suggestions regarding commitment have been followed in the vast bulk of cases. ${ }^{294}$ It would therefore be highly desirable for the diagnosing psychiatrists to be in a position to work closely with the staff within the court engaged in exploring alternatives. On the other hand, since few well-qualified psychiatrists are likely to be interested in performing diagnostic work only, placing full-time psychiatrists on the court staff may be ill advised. One possible approach would be for the state to assign the entire task of diagnosing and exploring alternatives to a community mental health center. ${ }^{295}$ Such a center might be less firmly in touch with the judge's wishes but would have the advantage of combining in one setting the range of mental health professionals who should contribute to the decision on placement. Operating in

293. See R. Dawson, supra note 283 , at 76-79 (1969) (indicating that probation reports are generally followed but often shaped by the probation officer's knowledge of the judge's predispositions).

294. See Cohen, The Function of the Attorney and the Commitment of the Mentally Ill, 44 Texas L. REv. 424, 449 (1966).

295. Community mental health centers are required, under federal regulations, to provide diagnostic services to other agencies including courts. See note 37 supra. One early survey of centers found some centers reluctant to examine court cases on an inpatient basis because wards were open and security could not be guaranteed. Ozarin \& Brown, New Directions in Community Mental Health Programs, 35 AM. J. ORTHoPSXCHIATRY 10 (1965). 
a closely analogous manner, at least one community mental health center has saved large numbers of persons from hospitalization by placing two of its social workers in the reception center of the state hospital and diverting to the center "a considerable majority" of those who live in the area it serves. ${ }^{206}$

A second alternative open to the states would be to place the burden of exploring alternatives on the staft of the state hospital to which the patient is to be committed. Most hospitals already employ social workers whose functions include the exploration of community resources. ${ }^{207}$ States could thus, without the cost of adding an entirely new staff within the courthouse, expand their existing hospital staffs to ensure the exploration of alternatives for all patients. Because of the appearance of efficiency here, many states, if forced to adopt some system, would probably select this approach. And much can be said for it. Hospital social workers may well be able to work more closely with staff psychiatrists in arranging for the return of the patient to the community and thus avoid altogether the need for a final commitment hearing. On the other hand, there are several great drawbacks to placing sole responsibility in the hospitals. Unless the hospital is equipped to examine patients on an outpatient basis-which many hospitals far from cities are not ${ }^{208}$ - it either will be unable to perform the exploration for patients well enough to remain at home pending a hearing or will have to seek the temporary commitment of everyone for diagnosis. How sadly ironic to lock someone in a hospital, even on a short-term basis, simply to permit staff to decide whether hospitalization is necessary.

Even if the hospital staff can examine the allegedly ill person as an outpatient, the hospital is still objectionable as the search instrument because it is caught in a disquieting conflict of interest in providing advice, ${ }^{299}$ a conflict that may raise doubts of constitutional

296. See R. Glasscote, J. Sussex, E. Cumming \& L. Smmtr, The Community Mental Health CENTER: AN INTERM Appraisal 29 (1969) (discussing Mid-Houston Community Mental Health Center).

297. In January 1970 there were 14,400 social workers employed in public and private mental health; over 4700 of these were employed in state and county mental hospitals. D. Jones, Staff and Manhours in Mental Health Facilities in the United States, Statistical Note 51, Survey and Reports Section, National Institute of Mental Health, Table II, at 10-11 (1971).

298. The large public mental hospitals are frequently at great distances from the cities they serve. See R. Rock, M. JAconson \& R. JANOpaut, supra note 2, at 69 . On the other hand, though generally not staffed today to perform searches into alternatives, receiving hospitals in large cities, which serve the distantly located hospitals, might perform the search. See id. at 66-69.

299. In a case in which a United States district court in the District of Columbia requested a public hospital to examine an alleged sexual psychopath, Dr. Winfred 
dimensions about the fairness of a hearing in which the judge relies on the hospital's recommendation. ${ }^{300}$ Asked to advise about community care for a particular person, hospital staff may well feel consciously or unconsciously the need to justify inpatient care and overstate its probable values. They are certainly likely to appear to do so. ${ }^{301}$ Hospitals may also in general attract as staff those with the greatest confidence in the efficacy of inpatient care.

A third possible approach is to make available to the ill person himself the resources to examine alternatives. In New York City, for example, the Mental Health Information Service, a governmentally funded agency, provides counsel to persons facing commitment and hires psychiatric social workers to aid the attorneys in searching for alternatives. ${ }^{302}$ Although New York courts neither acknowledge an obligation to employ the least restrictive alternative nor possess broad enough powers over other agencies to compel their cooperation, if the courts were so equipped, the model of the Information Service might provide a constitutionally acceptable structure for exploring alternatives. The experience in New York indicates that the Information Service has brought about a decrease in hospitalizations and an increase in out-of-court agreements between counsel and hospital staff for community placement and treatment of the patient. ${ }^{303}$ In the District of Columbia the new Public Defender

Overholser, then superintendent of the hospital, responded by letter to the court, inquiring

whether it is proper that physicians on the staff of St. Elizabeths Hospital should be called upon to determine whether a person not now in the Hospital as a patient should be examined by them to determine whether he should be sent to the Hospital. In civil cases I am sure that a question of this sort would be raised and I wonder whether it is entirely proper, whether legal or not, to make such an arrangement in a criminal case.

From the record in United States v. Allen, Crim. No. 438-60 (D.D.C. 1960), quoted in R. ARENS, MAKE MAD taE GULTY 72 (1969).

300. For cases in which judgments have been reversed because the judge or other decision-maker was unlikely to render an impartial judgment, see Tumey v. Ohio, 273 U.S. 510 (1927) (deprivation of property without due process when judge received a percentage of the fines he levied); Texaco, Inc. v. FTC, 336 F.2d 754 (D.C. Cir. 1964) (Chairman of FTC who had, before joining Commission taken a public stand on a case pending before the Commission found not in position to make impartial judgment).

301. See In re Murchison, 349 U.S. 133, 136 (1955) (due process requires not merely the prevention of "actual bias," but beyond this, the prevention of "even the probability" of bias).

302. A dated description of the Mental Health Information Service can be found in Note, The New York Mental Health Information Service: A New Approach to the Hospitalization of the Mentally Ill, 67 CoLUM. L. REv. 672 (1967). The addition of psychiatric social workers has been more recent. See S. BRAKEL \& R. Rock, supra note 2 , at 156 .

303. Zitrin, Herman \& Kumasaka, New York's Mental Hygiene Law-A Preliminary Evaluation, 54 MENTAL Hygiene 28, 31-34 (1970). 
Agency is developing its staff along essentially the same lines and seems to be experiencing similar success. ${ }^{304}$ Many states, however, do not now provide counsel to persons facing civil commitment. ${ }^{305}$ Those that do generally use a system of court appointments from the regular bar. ${ }^{306}$ The abysmal records of such court-appointment systems (under which lawyers are almost uniformly reported to spend little, if any, time preparing for hearings) ${ }^{307}$ makes abundantly clear that such systems should be held constitutionally inadequate to ensure that alternatives are explored.

Even with a promising model such as the Mental Health Information Service, a danger exists, somewhat like the danger of leaving the task to the hospital, that the agency cannot serve adequately as both advocate for the patient and adviser to the court. If its recommendations are regarded as simply an advocate's postur.ing, judges might understandably discount them. Perhaps the best system-more elaborate than the Constitution may require-would combine the three models: employing court and hospital personnel for those hospitalized prior to a hearing; employing court and mental-health-clinic personnel for those remaining in the community prior to the hearing; and providing to all persons counsel who are aided by psychiatric social workers.

Juvenile court systems now typically carry out the search for alternatives to incarceration through all three approaches suggested here. Judges receive advice on community placement from their own probation staff; whenever possible, juvenile institutions retain social

304. Interview with Robert Golten, Public Defender Agency, Aug. 10, 1971.

An instructive example of the valuable services that legal service agencies can perform in locating alternatives was, by happenstance, precipitated by the preparation of this article. In checking for me in the spring of 1972 on the last years of the life of Catherine Lake, the protagonist in the District of Columbia case discussed at several points in this article (see, e.g., text accompanying notes 143-46), the Public Defender Agency came upon Ms. Lake's sister, an aged, blind woman, confined in the same hos. pital that had held Ms. Lake. The sister had been a patient for six years and was eager to leave. In May 1972 a social worker working with the agency found a place for her in a local foster home (conversation with Jane Comerford).

305. As of 1970, "only twenty-four [states] provide for the appointment of counsel in all hospitalization cases in which the person alleged to be mentally ill has none." S. BRAKEL \& R. ROCK, supra note 2, at 54. On the constitutional obligation to provide counsel, see note 270 supra.

306. See S. BRACKEL \& R. Rock, supra note 2, Table 3.12, at 125-27.

307. See R. Rock, M. JACOBSON \& R. JANOPAUL, supra note 2, at 195.99 (describing commitment in Kansas); Cohen, The Function of the Attorney and the Commitment of the Mentally Ill, 44 TExAs L. REv. 424, 428 (1966) (describing commitment proceedings in Texas); Gilboy \& Schmidt, "Voluntary" Hospitalization of the Mentally Ill, 66 Nw. U. L. REv. 429, $447-49$ (1971) (describing the commitment process in Chicago, where public defender office represents persons facing hospitalization); Wexler, Scoville, et al., supra note 140 , at $33-35,51-60$ (commitments in Arizona); Note, supra note 135, at 913-16 (commitments in Iowa). 
workers and other staff to explore community resources that would permit the youth to return home; and the juvenile is provided with counsel who, at the time of commitment, also advances arguments for leaving him in the community. ${ }^{308}$

\section{B. The Power of Committing Courts To Compel Alternative Facilities To Cooperate}

The preceding section argues that the principle of the least restrictive alternative requires that states establish systems to ensure an adequate exploration of community-treatment opportunities for persons facing commitment. Even if states establish such systems, the principle can be undercut if community-based treatment programs are free to refuse court-referred patients. As a way of inducing legislatures to require community programs to cooperate, appellate courts might hold that committing courts may not commit a person to a hospital if a suitable community facility exists, whether or not the community facility is willing to accept him. ${ }^{309}$

Whether the principle should be held to reach so far poses a puzzling question. If courts do not have the power to compel the cooperation of publicly funded community clinics and the clinics can simply refuse to accept patients from the courts, ill persons may languish unnecessarily in the state hospital. Some clinics currently do receive cases through the courts ${ }^{310}$ but may resist large numbers of referrals fearing that such patients will in general pose serious behavioral problems or that the clinic itself will be held to a higher level of accountability than usual. ${ }^{311}$ On the other hand, empowering courts to force clinics to accept patients may compromise the maximum effectiveness of the clinics. Clinics might receive so many court referrals that they would be compelled to curtail their services to those who come to them voluntarily. Such a state of affairs in either the clinics or the hospitals would be deeply unfortunate. It penalizes those who come for help voluntarily at a time when most mental-health authorities wish to encourage voluntary treatment,

308. See, e.g., Hickey, $A$ Guide to Utilizing Juvenile Dispositional Facilities, in Second Annual Juvenile Practice Institute 101 (1971) (held in Washington, D.C., Nov. 5-6, 1971).

309. Courts could reach such a holding on essentially the same reasoning that would be used to compel the creation of systems for exploring alternatives: that it is necessary in order to protect the patient's right to avoid hospitalization when less restrictive alternatives are available. See text accompanying notes 285-87 supra.

310. C. Taube, Caseload of Federally Funded Community Mental Health Centers, 1969, Statistical Note 38, Survey and Reports Section, National Institute of Mental Health, Table C, at 5 (1971).

311. See note 295 supra. 
and leads to placement by a scheme bearing no necessary relation to the maximum efficacy of the clinic as an instrument of therapy.

Despite these dangers, I believe on balance it would be wise to give judges the power to compel the cooperation of public facilities in much the same way that they exercise such power over the public hospital. Judges probably will rarely wish to place a person in a facility or program that claims to be ill-suited to receive him. Moreover, judges should be permitted to take into account the manifold goals the state is seeking to serve through its community-based programs in deciding whether placing a particular individual there would permit the full range of state goals adequately to be served. It nonetheless does seem wise for the court to hold the club of compelled cooperation as a guard against unreasonable agency resistance. ${ }^{312}$ Some community facilities that are resolutely determined not to cooperate will find ways to conceal their improper reasons for refusing referrals, but others may respond to the judge's power by greater willingness to cooperate in establishing a close working relation with the court. Such relations will be indispenable to the success of efforts to deflect persons from involuntary hospitalization into community-based programs.

\section{G. The Appropriate Stage in Proceedings for Examining Alternatives}

Another perplexing procedural problem remains: by what stage in the commitment process must a committing court make a decision on alternatives? Today, many of the ill persons in hospitals have been brought there directly by families or police ${ }^{313}$ and held for several days or even weeks under emergency commitments before any hearing is conducted. ${ }^{314}$ Fraught with dangers of abuse, the emergency commitment system is under attack, thus far unsuccessfully, in the courts. ${ }^{315}$ For persons held under emergency procedures,

312. A difficult question is posed by the case in which hospitalization would be unnecessary for an indigent if certain private care-say a visiting nurse-were provided. Here is an existing alternative, the staff of which is perhaps willing to cooperate. The problem for the judge here is not one of power to compel cooperation but of power to order that compensation be paid to the private agency for its services. The issue here is essentially the same as that posed in the last section of this article-that is, can courts compel states to create new, less restrictive alternatives? See discussion in pt. V. C. infra.

313. Police are involved in about one fourth of all public hospitalization in this country. See R. Rock, M. JACOBSON \& R. JANOPAUL, supra note 2, at 87-105.

314. See S. BRAKEI \& R. Rock, supra note 2, at 42.45.

315. See Lessard v. Schmidt (E.D. Wis. Nov. 1971) (complaint), reported in 5 Cuenringmouse Rev. 766 (1972); Fhagen v. Miller, 29 N.Y.2d 348, 278 N.E.2d 615, 328 
the right to an exploration of less restrictive alternatives may prove without content. During the time when court staff or others might conduct the inquiry into alternatives, these patients would suffer the very trauma and anxiety, particularly severe in the initial days of commitment, ${ }^{316}$ that the principle of the least restrictive alternative should help avoid ever having to occur. A dilemma clearly exists. Some people pose such serious dangers to others or are so imminently suicidal that to delay commitment in order to permit a thorough inquiry into alternatives might lead to the death of others or render the question of alternatives moot by the ill person's own death. Banning precipitous civil commitment may also lead police to characterize ill persons' behavior as criminal to provide a different and possibly even less desirable handle for assuming forceable control. 317

Qualms may exist about the propriety of government preventing a person from taking his own life and about the capacity of courts and psychiatrists to identify those who in fact pose dangers to themselves or others, ${ }^{318}$ but it seems probable that courts will continue to permit summary commitment of ill persons thought imminently likely to commit harm to themselves or others. The Supreme Court has recently held in several cases that when government takes action against an individual bearing serious consequences for him, it must, as a general rule, offer him a hearing before, rather than after, taking the action. ${ }^{319}$ For example, welfare benefits may not be terminated or wages garnished before providing a hearing. The Court has, however, recognized the continued vitality of earlier decisions that permitted summary action in cases in which only an immediate response could prevent irreparable harm to the public and in which

$\overrightarrow{\text { N.Y.S.2d } 393 \text { (1972) (upholding constitutionality of New York's emergency admission }}$ procedures).

316. See E. Gofrman, supra note 83 , at 14-35, 146-69.

317. See Abramson, The Criminalization of Mentally Disordered Behavior, 23 HospITAL \& CoMmunity Psychiatry 101 (1972) (raising specter that new California commitment statute that greatly limits occasions permitting civil commitment is leading police to use the criminal process on patients previously hospitalized).

318. On the difficulties in predicting dangerousness in general and the special ineptitude of doctors in doing so, see Dershowitz, The Psychiatrist's Power in Civil Commitment: A Knife That Cuts Both Ways, Psychorogy TODAY, Feb. 1969, at 43.

319. Bell v. Burson, 402 U.S. 535 (1971) (hearing on probability of liability required before suspending driver's license of uninsured driver involved in accident); Wisconsin v. Constantineau, 400 U.S. 433 (1971) (hearing required before person considered an excessive drinker may be barred from taverns); Goldberg v. Kelly, 397 U.S. 254 (1970) (hearing required before welfare payments terminated); Sniadach v. Family Fin. Corp., 395 U.S. 337 (1969) (hearing required before wages garnished). See also Opp Cotton Mills, Inc. v. Administrator, 312 U.S. 126, 152-53 (1941) (hearing must be offered before administratively determined minimum wage is put into effect). 
the value of preventing the harm to the public was viewed as outweighing any harm inflicted on the individual against whom the summary action was taken. ${ }^{320}$ Thus, the Court has consistently approved the seizure, in advance of hearing, of allegedly spoiled foods or possibly dangerous medications. ${ }^{321}$

The dilemma in civil commitment cases is that both summary commitment and the failure to commit summarily can in the same case produce substantial and irreparable harm-it is a human life that the government is temporarily impounding, not allegedly maggot-infested hams. In any event, state courts seem to have resolved the dilemma consistently in favor of state power to commit prior to a hearing. ${ }^{322}$ The New York court of appeals, for example, recently upheld a provision of its code permitting persons to be held for fifteen days without a hearing if simply "alleged to be in need of immediate observation, care or treatment for mental illness." 328

The New York decision was unsound. Courts might indeed wisely invalidate even a commitment code that limits emergency commitments to those believed necessary to protect the public safety. They could do so either on the basis of the woefully inadequate capacities of psychiatrists and others in the mental health system to predict dangerousness to self or others, ${ }^{324}$ or, in a manner comparable to the Supreme Court's actions in some prior-hearing cases, ${ }^{325}$ because the risk of grave, even irreparable, harm to the public does not outweigh the interest of the allegedly ill person in his freedom. This belief that the individual's interest in freedom outweighs the community's interest in security does, after all, underlie the constitutionally based right to bail in criminal cases, and the considerations in civil commitment, though not identical (because, in theory, hospitalization offers treatment), are at least in substantial part the same. Of course, the same argument resting on the individual's interest in his freedom taken to its logical extreme could yield a

320. Goldberg v. Kelly, 397 U.S. 254, 263 n.10 (1970), citing North Am. Cold Storage Co. v. City of Chicago, 211 U.S. 306 (1908) (seizure of spoiled food), and Ewing v. My. tinger \& Casselberry, Inc., 339 U.S. 594 (1950) (seizure of mislabeled vitamins).

321. See cases cited in note 320 supra.

322. See In re Coates, 9 N.Y.2d 242, 173 N.E.2d 797, 213 N.Y.S.2d 74, appeal dismissed, 368 U.S. 34 (1961); Payne v. Arkebauer, 190 Ark. 614, 80 S.W.2d 76 (1935).

323. Fhagen v. Miller, 29 N.Y.2d 348, 278 N.E.2d 615, 328 N.X.S.2d 393 (1972). 324. See note 318 supra.

325. In Goldberg v. Kelly, 397 U.S. 254, 266 (1970), for example, the Court ordered New York to provide hearings prior to terminating welfare benefits despite its explicit recognition that the impact of such a requirement would be that New York City would be irreparably injured by having to continue payments to persons who would be found ineligible at the hearing and judgment-proof in any efforts at recoupment. 
holding that civil commitment is never permissible whether or not there has been a full hearing.

If courts do insist on permitting temporary commitments before a hearing in some cases-and I can easily conceive of cases in which a total ban on summary commitment would be deeply troubling ${ }^{326}$ -the Supreme Court's decision in other areas should probably lead to the following resolution of the issue: In those cases, but only those cases, in which immediate and substantial harm is thought probable for the individual or others, a court may conduct its inquiry into alternatives-and even into illness-while the individual is held on a temporary basis. ${ }^{327}$ Nonetheless, the committing court and the hospital should be required to perform an initial inquiry into alternatives as expeditiously as reasonably possible. Such a rule would permit the summary commitment not only of the suicidal and the assaultive but also of those apparently ill persons who, though not in danger of death, seem likely to deteriorate irretrievably without immediate inpatient care. ${ }^{328}$ On the other hand, what the rule would forbid is the common practice today of involuntarily committing in advance of an inquiry into alternatives those who behave peculiarly or are simply unable to care well for themselves but will irreparably harm neither themselves nor others if their commitment is postponed until after a review of alternatives. If hospital doctors would honor this standard-and it will be difficult to enforce otherwisemost patients should be spared inpatient hospitalization until after an inquiry into alternatives. ${ }^{329}$

In setting the timetable for exploring alternatives, courts should insist on explorations not merely before commitment but also after

326. Consider the person in a catatonic state, totally withdrawn into himself, who will not eat at all.

327. The Supreme Court of Missouri has accepted essentially this position. State ex rel. Fuller v. Mullinax, 364 Mo. 858, 269 S.W.2d 72 (1954). At the other extreme, some state courts have approved commitment prior to hearings for all mentally ill persons. See, e.g., In re Crosswell's Estate, 28 R.I. 137, 66 A. 55 (1907); In re Dowell, 169 Mass. 387, 47 N.E. 1033 (1897).

328. For those believed suicidal, assaultive, or "deteriorating," the dangers that the confinement while an inquiry into alternatives is going forward will later be found to have been unnecessary may be less than for other classes of patients: it is less likely for them that even after examination a court will find lesser alternatives equally effective for protecting the person or public.

329. Unfortunately, many hospital psychiatrists seem oblivious to legal standards. Concerned solely with providing treatment (and, by my own observations, with protecting their power to provide the treatment), such psychiatrists may well subvert any efforts to reduce the number of inessential emergency commitments. Substantial reduction in the number of unnecessary emergency commitments may thus be possible only by a cumbersome process of subjecting all commitments to immediate and automatic review. 
commitment-not merely at the outset of governmental intervention but even after commitment and an initial thorough inquiry. A later inquiry may be especially desirable after a hospitalized person has passed through an acute episode of illness and has entered a more stable period, because finding an alternative then may intercept his transfer within the hospital from a moderately well-staffed intensivetreatment ward to the sort of "extended treatment" or "rehabilitation" ward from which too few travelers ever return. ${ }^{830}$ Such a continuing inquiry may be seen as required by the principle of the least restrictive alternative itself or may be analyzed as part of the hospital's statutory or constitutional obligation to provide treatment. ${ }^{831}$

In those states that provide for periodic judicial review of commitments by the hospital or by the court, ${ }^{382}$ the reviewer should be required to include a reexamination of alternatives as part of its decision on the need for continued confinement. Moreover, the availability of less restrictive alternatives should also be justiciable at habeas corpus hearings of the sort traditionally available to the mentally ill to test whether they remain within the statutory criteria for commitment. In fact, each of the principal District of Columbia decisions dealing with the use of alternatives arose in the context of habeas corpus proceedings, not in the context of appeals from initial commitments. ${ }^{383}$

\section{GoING BEYOND}

\section{A. Reaching the Voluntary Patient}

The state's constitutional obligation to explore alternatives may not extend to the large and growing number of persons who commit themselves to hospitals voluntarily ${ }^{334}$ or to those hospitalized under special provisions for "nonprotesting" patients. ${ }^{335}$ If, as I have argued, the predicate for finding a constitutional obligation to explore alternatives is a state's threat to curtail a person's physical freedom, then the predicate is lacking when the state threatens nothing and merely responds to the citizen's request for care.

330. On the vast disparities in staffing and treatment between these two types of wards, see R. Rock, M. JAcobson \& R. JANOpaur, supra note 2, at 70, 223-26.

331. See S. BRAKEI \& R. Rock, supra note 2, at 165-66.

332. See compilation in id., Table 5.4, at 184-85.

333. Covington v. Harris, 419 F.2d 617 (D.C. Cir. 1969); Lake v. Cameron, 364 F.2d 657 (D.C. Cir. 1966).

334. See S. BRAKEL \& R. Rock, supra note 2, at 17-33; R. Rock, M. Jaconson \& R. JANOPAuL, supra note 2, at 34-38.

335. R. ROCK, M. JACOBSON \& R. JANOPAUL, supra note 2, at 38-40. 
The voluntary patient's freedom is, however, often more tenuous than it appears. First, in most states, hospitals may hold him without hearing for several days, even weeks, after he has requested his release. ${ }^{336}$ Second, many persons voluntarily commit themselves only under the implied threat that they will otherwise be committed against their will. ${ }^{337}$ And, third, patients are often misled about the nature of the "voluntary" status and further misled into believing that hospitalization is in their best interest. A patient often rests his decision to enter or remain in a hospital on a belief, instilled or nursed by hospital staff, that he "needs" to be hospitalized,"s38 when all the staff has any foundation for claiming is that he suffers from a mental illness and needs some form of help somewhere.

Somewhat tender constitutional arguments can thus be advanced that, because of the hospital's power to hold the voluntary committee and the threatening circumstances under which many patients volunteer, states must treat these commitments as involuntary at least to the extent of searching and providing opportunity for placement in community facilities for the "voluntary" patient in the same manner that they must for the court-committed patient. ${ }^{339}$ Short of this position, because of the danger of misimpression about the necessity for hospitalization conveyed to the voluntary patient

336. In a few states, a voluntary patient may leave whenever he wishes. More commonly, he must give notice of an intention to leave and then can leave if within a few days the hospital has not filed initial papers for his commitment with the appropriate court. See compilation in S. BRAKEI \& R. ROCK, supra note 2, at Table 2.1, at 27-33.

337. See the description of the commitment process in Illinois in Gilboy \& Schmidt, supra note 307 , at 433 , $438-39$ (finding that $40 \%$ of voluntarily committed patients have been brought to hospitals by the police who, if voluntary commitment does not result, will generally sign papers to commit them involuntarily).

338. In viewing commitment proceedings, I have been struck by the fact that all participants keep trying to assure the patient that they are concerned solely with his best interests. The Rock, Jacobson and Janopaul book provides a common example from a commitment hearing in Ransas:

JUDGE [To the patient]: Are there any questions you would like to ask?

Patient: No, it's just that I would like to go home.

JUDGE: Rest assured that we are all interested in what is best for you. Thank you

for talking with us. [The patient was then ordered to be committed.]

R. ROCK, M. JACOBSON \& R. JANOPAUL, supra note 2, at 197.

339. The arguments for requiring more protective procedures for the voluntarily committed, based on the coercion that inheres in their decision to commit themselves, are reviewed in Gilboy \& Schmidt, supra note 307, at 449-51. The authors conclude that a recent Supreme Court decision refusing to invalidate a guilty plea even when induced by the defendant's expectations of leniency (Brady v. United States, 397 U.S. 742,751 (1970)) reduces the likelihood that courts will accept arguments for greater protections for the person who voluntarily commits himself fearing involuntary commitment otherwise. In my view, the decision in Brady was so greatly influenced by the Court's view of the social utility served by guilty pleas (see 397 U.S. at 752) that the decision should be viewed as having little bearing on the issue of "voluntary" admissions to hospitals. 
by the hospital's acceptance of him as a patient, courts might require hospitals to warn him about the limited extent of the exploration for alternative methods of treatment for him. ${ }^{340}$ The second remedy seems of little worth (in many cases, no more likely to dissuade the ill person than would warning a drowning man that you can offer him only a frayed rope).

Even if courts found that persons involuntarily committed are entitled to a full inquiry into less restrictive alternatives, hospitals would probably be forced to ignore the requirements unless provided with more adequate social service staffs to search for alternatives than most hospitals can currently claim. ${ }^{341}$ On the other hand, if adequately staffed to search out community alternatives, hospitals would probably provide equally careful searches for the involuntary and voluntary patients. ${ }^{342}$ The Hippocratic oath draws no distinctions based on a patient's voluntary status, and hospitals, so far as I have observed, rarely give favored treatment to involun. tary patients based on fear of a court's intrusion. Given the comparative efficacy of community facilities, the states would, of course, be wise, wholly apart from constitutional requirements, to require searches for alternatives for all classes and equip their hospitals to carry out these searches.

\section{B. Requiring the Use of Alternatives Even When They Are Less Effective Than Hospitalization}

The narrowest view of the principle of the least restrictive alternative-and the view generally advanced in this article-leads to prohibiting inpatient hospitalization only when an alternative permits equal or better service of the state's goals. Under this view, an individual's involuntary hospitalization would be immune from constitutional attack when alternatives stretch even a millimeter less far toward serving fully the state's interests.

Such a rigid view of the principle is not inevitable. Courts might well require the use of alternatives in a much broader range of cases. In the context of civil commitment, courts might compel the use of community alternatives, even when they serve the state's goals somewhat less well than hospitalization, on those occasions when the

340. See Gilboy \& Schmidt, supra note 307, at $441-43$.

341. On the limitations on staffing in public hospitals, see text accompanying notes 73-77 supra.

342. A few states provide by statute for equal treatment for all classes of patients. See, e.g., IOWA CODE ANN. \& 226.10 (1969). In these, a holding that involuntarily committed patients have an affirmative right to be treated might also be held to apply to the voluntarily committed. 
federal constitutional interest in an extra degree of protection for a person's freedom of movement afforded by the use of the alternative is believed to outweigh the state's interest in the greater degree of protection of its goals afforded by hospitalization. Commitment judges would have to weigh values-protection and freedomthat are related but cannot in fact be quantified absolutely or relatively; he would nevertheless be making the kinds of judgments that judges must make every day. ${ }^{343}$

Ample authority exists in Supreme Court decisions for requiring the broader view of the principle. In Southern Pacific Co. v. Ari$z_{\text {zona }}{ }^{344}$ for example, the Court struck down as an undue burden on commerce an Arizona statute limiting the length of trains to no more than fourteen passenger cars and seventy freight cars. Arizona argued that it needed the regulation to reduce the incidence of "slack action" accidents, exacerbated by longer trains. As a standard for judgment, the Court did not declare that the regulation was to be upheld unless the state's goals could be as fully served by permitting longer trains. Rather, the Court regarded "the decisive question" to be "whether in the circumstances the total effect of the law as a safety measure . . . is so slight or problematical as not to outweigh the national interest in keeping interstate commerce free from interferences which seriously impede it" 345 and concluded that the law, "viewed as a safety measure, affords at most slight and dubious advantage, if any, over unregulated train lengths." 346

The Court has engaged in similar weighing, with less candor, in many other cases, ${ }^{347}$ including cases involving the rights most

343. A judge's decisions in granting bail, granting postponements of proceedings, admitting certain evidence at trial (such as evidence of a criminal defendant's prior crimes), and imposing sentence all may involve conflicting values that the judge must adjust in the "sound exercise of his discretion."

344. 325 U.S. 761 (1945). See also Younger v. Harris, 401 U.S. 37, 51 (1971) ("[W] here a statute does not directly abridge free speech, but .... tends to have the incidental effect of inhibiting First Amendment rights, it is well settled that the statute can be upheld if the effect on speech is minor in relation to the need for control of the conduct and the lack of alternative means for doing so.").

345. 325 U.S. at 775-76.

346. 325 U.S. at 779.

347. In first amendment cases, for example, when it has invalidated a regulation on the ground that the state should have used a less restrictive alternative for achieving its goals, the Court has sometimes suggested an alternative plainly inadequate for the state's needs and failed to indicate any recognition of the inadequacy. See, e.g., Baird v. State Bar, 401 U.S. 1 (1971) (information already supplied by bar applicant stated by Court to be fully adequate for state purpose in investigating character though, as suggested in Justice Blackmun's dissent, 401 U.S. at 11, 2l-22, it may not in fact have revealed all information the state had a legitimate interest in learning); Martin $\nabla$. Struthers, 319 U.S. 141 (1943) (signs indicating bellringers unwelcome offered as alter- 
drastically curtailed by civil commitment-travel and association. The Shelton and Aptheker cases are examples of decisions in which the alternatives intimated by the Supreme Court were almost certainly less adequate than the challenged regulations to advance the legislature's legitimate purposes, but the Court believed that the individual's interest in association and travel outweighed the government's interests in the curtailment of these rights. ${ }^{348}$ On the other hand, even when cases have involved so sacred a right as freedom of expression, the Court has occasionally upheld a statute when it believed that no adequate alternatives existed for serving a governmental purpose, without weighing the value derived from serving that purpose against the value in protecting free expression. ${ }^{340}$

In short, once courts begin to regard an area of conduct as constitutionally favored, few natural limits appear either on the extent of the constraints courts can place on government intrusions or, conversely, on the constraints they can place on the protected freedom itself in the name of serving some pressing legislative interest. ${ }^{350}$ Freedom from bodily confinement is, I have argued, an interest of constitutional dimensions under state and federal constitutions. ${ }^{351}$ At a minimum, it-and other freedoms-ought to be

native to ban on door-to-door solicitation); Schneider v. Town of Irvington, 308 U.S. 147 (1939) (ban on littering suggested as alternative to ban on distribution of leaflets).

More disingenuously still, the Court has sometimes asserted that effective, narrower alternatives existed for serving the legislature's goals but has failed either to state what those goals were or suggest specific alternatives for serving them. See, e.g., United States v. Robel, 389 U.S. 258 (1967); Elfbrandt v. Russell, 384 U.S. 11 (1966); Louisiana ex rel. Gremillion v. NAACP, 366 U.S. 293 (1961); Shelton v. Tucker, 364 U.S. 479 (1960). See also Israel, Elfbrandt v. Russell: The Demise of the Oath, 1966 Sur. Cr. REv. 193, 218-19.

In still other cases, Justices have disguised their weighing by describing a specific alternative as "adequate" or claiming that an alternative will "suffice" without acknowledging the value judgments those terms carry about the worthiness of the state's interests or the comparative strength of the federal constitutional interest. See Dean Milk Co. v. City of Madison, 340 U.S. 349, 354 (1951) ("reasonable and adequate alternatives are available"); School Dist. v. Schempp, 374 U.S. 203, 281 (1963) ("IT] state acts unconstitutionally if . . . it uses religious means to serve secular ends where secular means would suffice.') (Brennan, $J$., concurring).

348. See text accompanying notes $178-79$ supra.

349. See note 168 supra and accompanying text. See also Adderley v. Florida, 885 U.S. 39 (1966) (especially Justice Douglas's comments in dissent on the majority's analysis, 385 U.S. at $48,54-55$ ).

350. For a caustic view of the standardless flexibility of the Court's handling of constitutional doctrines, see Kurland, Foreword, Equal in Origin and Equal in Tille to the Legislative and Executive Branches of the Government, 78 HARv. L. REV. 148, esp. 169-75 (1964). See also Goldberg v. Kelly, 397 U.S. 254, 271, 276 (1970) (Black, J., dissenting) ("Today's balancing act requires a 'pre-termination evidentiary hearing, yet there is nothing that indicates what tomorrow's balance will be." Justice Black then goes on to list a series of probable extensions.).

351. See pt. III. B. supra. 
protected against unnecessary curtailment, but existing case law does not point ineluctably toward according it any greater level of protection.

With ample precedent either way, I believe a court would be well warranted, at least initially, in holding the minimum regarding the required use of alternatives to civil commitment: that is, that commitment is impermissible only if the state's goals can be served fully as effectively by the lesser alternative. I reach this conclusion relúctantly. It may not merely lead to, but approve, locking people up solely for protection without requiring weight to be attached to their interest in freedom. Under this standard, the state may with impunity confine aged persons such as Catherine Lake who are believed likely to wander confusedly, ${ }^{362}$ if a court finds protection the only goal to be served and no alternatives equally protective. ${ }^{353}$ I nonetheless believe this narrow view justified for two practical reasons.

First, it must be remembered that in civil commitment proceedings, if the principle of the least restrictive alternative is accepted, state committing courts or agencies will have to begin considering alternatives on a case-by-case basis. If only alternatives that are fully as effective as hospitalization must be ordered, the task for the committing courts will be complex but manageable-essentially like the task of criminal courts when making probation decisions. However, appellate courts will seriously ravel the lines of reasoning state committing courts must undertake if they require courts to go beyond assessing the effectiveness of alternatives and decide in each case whether the Constitution requires that a somewhat less effective alternative be used because of the greater interest in permitting freedom. Although a judge can be aided by hospital doctors and others in making factual assessments of the likely effectiveness of various treatment modes, no one but the judge can determine the weight the Constitution requires be attached to freedom. ${ }^{354}$ The

352. See text accompanying notes 143-49 strpra.

353. The danger that some judges might rarely find alternative dispositions acceptable is increased by the multiplicity of purposes commitment is expected to serve. See pt. II. B. supra. When a state or federal legislative purpose is legitimate but trivial, denying liberty to serve the purpose may seem particularly galling. In United States v. O'Brien, 391 U.S. 367 (1968), the Supreme Court upheld a statute imposing substantial criminal sanctions for the burning of draft cards, finding no other alternative suited to achieve Congress's legitimate purposes (which I personally consider trivial in relation to the first amendment interest) of easing the administrative burdens on the Selective Service System, facilitating communication by the registrant with his board, serving as a reminder to the registrant of his obligation, and reducing the use of mutilated cards for deception. 391 U.S. at 378-80.

354. The requirement of a case-by-case inquiry into what the Constitution demands would be especially troublesome in those states in which some committing judges are 
Supreme Court has on several occasions, it is true, remitted legislatures to alternatives that, if adopted, would have required trial judges to perform case-by-case inquiries of a kind previously avoided. ${ }^{355}$ In none of these cases, however, would the required determinations have involved trial judges in repeated acts of balancing federal constitutional interests against state interests. Though some judges might develop workable rules of thumb for taking into account the constitutional interests, others might justifiably resist being placed every day in the position of performing delicate constitutional balancings of a sort that generally divides the Supreme Court on the few occasions each term that it engages in such weighing.

A second justification-also pragmatic-for requiring that a less restrictive alternative to hospitalization be accepted only if fully as effective as hospitalization is that, if the states did establish adequate mechanisms and staff for exploring alternatives, this limited relief would probably produce as high a level of reliance on alternatives as would any standard appearing to require broader use. In many cases under the narrow standard, judges are likely to find the alternatives to commitment fully as effective. ${ }^{356}$ Moreover, once courts begin making inquiries into alternatives as a matter of course, the inquiries may breathe a life of their own. Many judges may begin to embrace less restrictive alternatives that bristle with risks, simply because they begin to recognize the shortcomings of hospitalization or the glimmers of hope for success in largely untested communitybased programs. They may, like some juvenile and family court judges, begin to immerse themselves in the development of new alternatives. $^{357}$ Conversely, for those judges who strongly resist em-

nonlawyers and in those states in which mental health boards or commissions composed solely or primarily of nonlawyers perform the commitments. See note 135 stepra.

355. See, e.g., Stanley v. Illinois, 40 U.S.L.W. 4371 (U.S. April 3, 1972) (proceeding to take custody of his child away from unwed father unconstitutional without case-bycase determination of parental fitness); Camara v. Municipal Court, 387 U.S. 523 (1967) (system of warrantless health-inspection searches of residential dwellings without owner's consent must be replaced by searches, with warrants, obtained from judge or other impartial official on showing of "probable cause" for search); Smith v. California, 361 U.S. 147 (1959) (conviction of bookseller for purveying pornography unconstitutional without proof that bookseller was in fact aware of book's pornographic content).

356. See pt. II. C. supra.

357. Judge Justine Wise Polier of the Family Court of New York City is a. justly celebrated example of a judge who has strived to develop alternatives to confinement. A recent example of her efforts is the report of a committee she co-chaired with Judge Phillip D. Roache of the same court. Committee on Mental HeAlth Services Inside and Outside of New York, Juvenile Justice Confounded: Pretensions and Realitics of Treatment Services (1972). 
ploying alternatives, imposing a broader obligation to employ them is unlikely to alter their conduct. Unless appellate courts intervened with fixed rules-an unlikely prospect-a commitment judge reluctant to employ alternatives would probably make findings in every case that community alternatives are unsatisfactory by whatever margin he feels he must in order to be safe in refusing to use them.

\section{Forcing the State To Create Less Restrictive Alternatives}

Catherine Lake, the senile petitioner in the District of Columbia case establishing the obligation of courts there to examine less restrictive alternatives, spent the remaining five years of her life in a public mental hospital. ${ }^{358}$ She died in April 1971, having received no visitors in the last year of her life. She did not need to be in a hospital. In the committing judge's view, a nursing home or similar residential facility providing some substantial measure of supervision, but not totally preventing access to the outside world, would have been sufficient. ${ }^{359}$ Such facilities-even ones of the sort the Nader study exposed ${ }^{360}$-were simply unavailable in the District of Columbia for most aged people as poor as Ms. Lake. ${ }^{361}$

For her, the principle of the least restrictive alternative proved a mirage, beckoning with hope and dissolving in disappointment. In many states, the principle would breed similar disappointment for many kinds of patients. ${ }^{82}$ In a commitment proceeding in Detroit, a judge told me that there was little point in requiring a search for community alternatives in most mental health cases because alternatives simply do not exist. ${ }^{303}$ Across the country, the development in the last decade of community-based residential and outpatient programs for the mentally ill has been rapid but has simply not kept pace with the demand. ${ }^{364}$ Nor has it kept pace with the research indicating their potential.

The failure to develop more extensive community-based pro-

358. Letter to the author from Harry Fulton of the District of Columbia Public Defender Agency, Dec. 13, 1971, on file with the Michigan Law Review.

359. See Lake v. Cameron, 267 F. Supp. 155, 159 (D.D.C. 1967) (case on remand). 360. See C. Townsend, Old Age: The LAST Segregation (1971).

361. See Hearings Before the Subcomm. on Constitutional Rights of the Senate Comm. on the Judiciary, 9lst Cong., 2d Sess., at 319, 324-25 (1970) (testimony of Dr. Sherman Kieffer, Director, National Center for Mental Health Services, Training and Research of St. Elizabeths Hospital, Washington, D.G.).

362. See note 38 supra.

363. In re Heard (Wayne County, Mich., P. Ct., hearing on Feb. 11, 1972).

364. See R. Glasscote, J. Sussex, E. Cumming \& L. Smith, supra note 296, at 31-32. 
grams poses a simple but perplexing question: For how much longer shall government be permitted to deny people their freedom, when it might easily develop programs and facilities that would permit both freedom and the service of the government's legitimate goals? Recall the simplicity of the alternative to incarceration found so successful in Pasamanick's experimental program in Louisville: seriously psychotic patients lived at home on medication with periodic visits from nurses. ${ }^{305}$ If such a home-based program really would serve the state's interests, should the state nevertheless be permitted to continue indefinitely to hospitalize such people against their will by simply refusing to develop such programs? I am certain that the tone of my questions conveys my belief that the state should not be permitted to do so. But I do have a less rhetorical question more difficult to answer: By what process can citizens compel their states to reshape their mental health programs?

The obvious and traditional route for change has been the political process-through the ballot and pleas to the legislature. In the past few years, however, many legislatures, facing costs rising faster than revenues, have either pared the budgets of mental health programs or cut back on their rate of expansion. ${ }^{360}$ The mentalhealth lobby, though ardent, is neither rich nor widely feared. In some states, courts may be able to prompt legislatures to act. Two theories for judicial intervention can be offered: the developing right to treatment and the principle of the least restrictive alternative. Each may be instrumental in forcing change, yet at the same time responsive to the appropriate interests of the states.

Courts that have shaped a justiciable right to treatment for patients in hospitals have reasoned that, under the due process clause, states cannot be permitted to lock people up for their care and treatment and then fail to provide-or make a bona fide effort to provide -a decent level of care. ${ }^{367}$ Applied until recently only in suits

365. See text accompanying notes 105-09 supra.

366. In 1971, as to their public mental hospitals, four states decreased per patient expenditures; twenty-four others increased expenditures but increased them at a lesser rate than they had increased them over the period 1967-1970. H. Bethel \& $R$. Redick, supra note 1, Table 7, at 11. See also Clurman, The Patients Can Walk Out at Any Time at Bronx State Hospital, N.Y. Times, April 2, 1972, \& 6 (Magazine), at 14, 20 (describing the funding squeeze in New York).

367. See, e.g., Rouse v. Cameron, 373 F.2d 451 (D.C. Gir. 1966) (decided on statutory grounds but indicating a constitutional basis); Nason v. Commonwealth, 353 Mass. 604, 233 N.E.2d 908 (1968) (implying a constitutional basis); People v. Bargy, No. 32784 (Wayne County, Mich., Cir. Ct., Jan. 12, 1970) (Gilmore, J.). 
brought by individual patients to secure their own treatment or release, the right has excited considerable interest within the legal profession ${ }^{368}$ and alarm among many psychiatrists, ${ }^{369}$ but has spurred little, if any, improvement in the quality of care provided in institutions. ${ }^{370}$

In the past year, however, a right-to-treatment suit with spurs and considerable promise has been flourishing in a federal district court in Alabama. In this case, Wyatt $v$. Stickney, ${ }^{371}$ patients involuntarily committed to two large state hospitals brought a class action against the hospital administrators alleging a violation of their constitutionally protected right to treatment. Two prestigious national mental organizations and the Department of Health, Education, and Welfare joined them as amici curiae. ${ }^{372}$ After an extensive trial, Chief Judge Frank $M$. Johnson found that many patients received no treatment whatever and others only treatment that fell well below any standard of minimal adequacy. ${ }^{373} \mathrm{He}$ then ordered the state to move rapidly to provide "such individual treatment as will give each [patient] a realistic opportunity to be cured or to improve his or her mental condition;"374 subsequently he entered a further order fixing detailed standards by which the adequacy of the care at these hospitals will be judged. ${ }^{375} \mathrm{He}$ expressly warned that he will

368. See, e.g., Symposium on the Right to Treatment, 57 GEO. L.J. 673-890 (1969) (ten articles).

369. See Council of the American Psychiatric Assn., Position Statement on the Question of Adequacy of Treatment, 123 AM. J. PsYchiatry 1458 (1967) (implying that adequacy of treatment is a question for doctors, not for courts).

370. See Halpern, A Practicing Lawyer Views the Right to Treatment, 57 GEo. L.J. 782, 784 (1969).

371. One of the many orders in the case can be found at 325 F. Supp. 781 (M.D. Ala. 1971). A recent article is Drake, Enforcing the Right to Treatment: Wyatt $v$. Stickney, 10 AM. CRIM. L. REv. 587 (1972). The papers in the case can be obtained through the counsel for the amici curiae, American Psychological Association, American Orthopsychiatric Association, and American Civil Liberties Union: The Center for Law and Social Policy, 1600 20th Street, N.W., Washington, D.C. 20009.

372. For the mental health organizations represented, see note 371 supra. Judge Johnson invited the participation of the United States as amicus curiae, $325 \mathrm{~F}$. Supp. at 786. The United States has appeared through the Department of Health, Education, and Welfare, filing papers in support of the plaintiff's position.

373. 325 F. Supp. at 784.

374. 325 F. Supp. at 784.

375. The court ordered implementation of a plan covering every facet of hospitalization. Wyatt v. Stickney, Civil Action No. 3195-N (M.D. Ala.), Order of April 13, 1972, at 4. The order included a list of patient rights, minimum staffing rations and qualification, required physical facilities, minimum nutritional standards, and requisite individual treatment plans. Id. at 9-21 (Appendix A, "Minimum Constitutional Standards for Adequate Treatment of the Mentally IIl"). 
not consider lack of staff or facilities a justification for providing less than adequate care. ${ }^{376}$ Indeed, in a phase of the suit attacking the particularly inhuman conditions at an institution for the retarded, he has ordered the state either to close the institution or to hire 300 new personnel within four months. ${ }^{377}$

The Wyatt litigants and Judge Johnson have, quite understandably, concerned themselves almost solely with the quality of care within Alabama's deplorable institutions. And courts in general might hold that, if a state provides "adequate" care within its institutions, the right to treatment does not require the creation of community-based facilities. ${ }^{378}$ The implications of the right-to-treatment cases, however, extend much further. Courts could appropriately hold that, given the known shortcomings of inpatient hospitalization, a state can be considered to provide "adequate treatment" for those whom it seeks to control against their will only by creating community-based programs as a supplement to institutional care.

The principle of the least restrictive alternative can reach as far as the right to treatment. Far less brittle in its logic, ${ }^{370}$ the principle, 1971).

376. Wyatt v. Stickney, 334 F. Supp. 1341, 1344 n.3 (M.D. Ala.) (Order of Dec. 10, 377. Wyatt v. Stickney, Civil Action No. 3195-N (M.D. Ala.), Order of March 2, 1972.

378. Nearly all writers about the right to treatment have argued solcly for improving the quality of care within hospitals, though at least one writer, Morton Birnbaum, has mentioned the importance of aftercare programs. See Bazelon, Implementing the Right to Treatment, 36 U. CHI. X. REv. 741 (1969); Birnbaum, A Rationale for the Right [to Treatment], 57 GEo. L.J. 752, 770 (1969) (though focusing largely on the quality of care within hospitals, the author, a psychiatrist, stated: "It is therefore the hope of this writer that the concept of the right to treatment will include a requirement that some kind of halfway house be available to accept those persons who are suitable for discharge from public mental hospitals but lack someone to accept the responsibility for them.'); Halpern, supra note 370 .

379. Judge Johnson stated the constitutional argument for a right to trentment as follows: "To deprive any citizen of his or her liberty upon the altruistic theory that the confinement is for humane therapeutic reasons and then fail to provide adequatc treatment violates the very fundamentals of due process." Wyatt v. Stickney, 325 F. Supp. 781, 785 (M.D. Ala. 1971). See similar language in Rouse v. Cameron, 373 F.2d 451, 453 (D.C. Cir. 1966). He further asserted that the only constitutionally permissible basis for involuntary commitment is treatment as opposed to "mere custodial care." 325 F. Supp. at 784 .

Despite Judge Johnson's claim, treatment is probably not the only constitutionally permissible justification government has for incarcerating people who are not criminals. Government is also probably constitutionally justified in locking up people who are dangerous to themselves or others. State courts have repeatedly affirmed this power (see Note, Civil Commitment of the Mentally Ill: Theories and Procedures, 79 HARv. L. REv. 1288 (1966)), and even the plaintiffs in Wyatt appear to concede so. If locking up people who are ill and dangerous is constitutionally permissible (because it serves legitimate purposes), I am uncertain why the state has any duty other than to treat 
even in its most simply stated form, can justify a holding that states must not restrain a person in a mental hospital if fully as effective programs that are less restrictive of liberty might be employedwhether or not such programs are currently in existence in the state. In numerous cases arising under the commerce clause, ${ }^{380}$ the first amendment, ${ }^{381}$ and the rights of travel ${ }^{382}$ and association, ${ }^{383}$ the Supreme Court has done just that-invalidated legislation when persuaded that a less restrictive alternative would protect the government's interests even though no legislation in existence at the time authorized the alternative. In these cases, the states, if they wished to continue to protect their legitimate interests, were compelled to adopt new systems or procedures more protective of the endangered constitutional liberties.

A broad holding requiring the creation of new alternatives to commitment under either the right to treatment or the principle of the least restrictive alternative would communicate to governments in an appropriate manner the high price they must pay for taking away people's freedom-that they may do so only when necessary and only when they are willing to make an effort to provide treatment that may keep the ill person from losing his freedom again.

such persons humanely unless the duty to do more flows from the simple notion that liberty is important and we are going to insist that the price for taking liberty is a bona fide effort to restore it as soon as possible. If judges who rely on the right to treatment would acknowledge that the right flows from just so simple a notion-the notion of the importance of freedom-their opinions would be more compelling. $C f$. Goodman, Right to Treatment, The Responsibility of the Courts, 57 GEO. L.J. 680, 680 (1969) ("Where deprivations of liberty are concerned, we will no longer justify these divestments or the flimsiness of the procedures under which they are initiated by referring to glib, but unfulfilled, legislative promises or purported, but illusory, humane goals.").

380. In the Dean Milk case, for example, the Court struck down a Madison, Wisconsin, ordinance forbidding the sale of milk processed beyond a certain number of miles from the center of town on the ground that the city had several effective alternatives it could use to protect against unsafe milk, none of which would involve as grave an imposition on interstate commerce. Dean Milk Co. v. City of Madison, 340 U.S. 349 (1951). Most prominent among these alternatives was an elaborate inspection system recommended by the United States Public Health Service, not currently authorized by Wisconsin legislation. See 340 U.S. at 355-56. See also Bibb v. Navajo Freight Lines, 359 U.S. 520, 530 (1959); Bald̋win v. G.A.F. Seelig, Inc., 294 U.S. 511, 524 (1935). (1964).

381. See Elfbrandt v. Russell, 384 U.S. 11 (1966); Baggett v. Bullitt, 377 U.S. 360

382. Aptheker v. Secretary of State, 378 U.S. 500 (1964), discussed at text accompanying note 178 supra.

383. Shelton v. Tucker, 364 U.S. 479 (1960), discussed at text accompanying note 179 supra. 
The hardest problem for lawyers interested in bringing suits of this sort will be to develop acceptable standards for determining just how high a price governments should be compelled to pay. Few, if any, of the Supreme Court cases that have insisted on the use of alternatives that were not yet created have compelled the creation of programs nearly so costly as vast new community-based alternatives to commitment. ${ }^{384}$ Wyatt in its present form may well cost Alabama annually millions of dollars in scarce revenues; if the suit's scope were expanded to demand an adequate system of outpatient care, many more millions might be entailed each year. Even if the state could offset much of the cost by closing down parts of its hospitals and rechanneling the savings into the required new programs, ${ }^{385}$ a court order might still have the impact of taking jobs away from many current hospital personnel or, at the least, of forcing a massive relocation and retraining of personnel.

Under either theory, further difficulties exist, wholly apart from dollar or resource cost, in determining the criteria for judging what sorts of community-based programs should be required. The right to treatment, typically held to require "adequate" care, ${ }^{386}$ might be found to demand an "adequate" system of community care tailored to aid the ill in avoiding hospitalization or rehospitalization. Unfortunately, even less agreement exists today about the components of an adequate system of community care than about the components of adequate hospital care. ${ }^{387}$ Complicating matters even more, the

384. If Brown v. Board of Education, 347 U.S. 483 (1954), is seen as a case in which the Court ordered the creation of alternatives not yet in existence in Kansas, the financial costs implicit in the Court's order might have equalled the cost of vastly expanded mental health programs. In most other Supreme Court cases costs would have been slight. See notes 380-83 supra. Even in Dean Milk, where the most elaborate alternative was suggested, the costs of the inspection system could presumably have been passed on to the milk producers instead of being borne by the state.

385. It seems clear that the per-patient costs of treating a person on an outpatient basis or even in halfway houses is significantly less than treating him in a hospital, where costs of attendants (who serve largely as guards) are so high. See R. Grasscote, J. Gudeman \& J. Elpers, supra note 53, at 24; Wilder, Levin \& Zwerling, $A$ Two-Year Follow-Up Evaluation of Acute Psychotic Patients Treated in a Day Hospital, 122 AM. J. OF PsYchiatry 1095 (1966). On the other hand, one phenomenon of the community mental health movement is that availability of programs based in the community brings many more people voluntarily into the mental health system than would otherwise seek its services. Moreover, the present level of expenditures in community-based clinics may not be nearly high enough to provide the quality of service within those clinics that their founders would like. See R. Glasscote, J. Sussex, E. Cumming \& L. SMrrh, supra note 296, at 7.

386. See cases cited in note 367 supra and articles in note 368 supra.

387. Standards for quality of care in hospitals were until 1958 published at regular 
principle of the least restrictive alternative might seem, at least at first blush, to demand not merely "adequate" community-based programs, but rather the optimum-those programs, regardless of cost, that will permit the maximum number of ill persons to avoid hospitalization while serving the goals the states seek through commitment. Citing the principle, courts might conceivably demand dozens of new outpatient clinics, scores of well-staffed, humane nursing homes, and troops of trained visiting nurses.

The prospect of such a far-reaching decree might make visions of sugarplums dance in the heads of advocates of community-based programs, but is likely to terrify all but the most intrepid judge. A decree need not, however, extend so far. The right to treatment demands only treatment that is "adequate," and the concept of adequacy, however fluid and inexact, ought to permit some consideration of the limits of state resources and the other demands on those resources. ${ }^{388}$ Even in a suit based on the principle of the least restrictive alternative, the added costs for the state ought not be ignored by a court. Treatment and protection may be the only goals with which a committing judge need concern himself in his search for alternative placements for a specific individual, but the over-all costs

intervals by the American Psychiatric Association. See STANDARds for FosprTals AND GuINICs (1958). Only in more recent years has the Association given equal attention to standards for the full range of community facilities, and as to such facilities, the newer standards are quite general, whereas the earlier ones were much more specific (including, for example, recommended staff-patient ratios). Compare id. with STANDARDS For PSYchiATRIC FAcrimies 68-79 (1969). The amici curiae in Wyatt submitted twenty-four pages of standards for care in the hospitals under attack; a high portion of these standards have been agreed upon by the defendants. (See Proposed Standards for Adequate Treatment of the Mentally Ill of Amici Curiae, February 2, 1972, indicating in brackets standards accepted by all parties.) I think it unlikely that any such agreement could be obtained with regard to community care facilities. See generally Rowe, Barriers to the Establishment of a Comprehensive Community Mental Health Center, in Community PsychiatRy, supra note 21, at 47.

388. The financial burden of requiring alternatives may seem more pressing in light of the fact that any order of a court would place burdens on the state, not the federal government, and yet it is the federal government that has the massive share of tax revenues and that has borne much of the cost of developing community-based mental health programs. The federal government in 1969 bore $34.3 \%$ of the costs of operating 205 community mental health centers across the country (C. Taube, Expenditures and Sources of Funds-Federally Funded Community Mental Health Centers, Statistical Note 43, Biometry Branch, Survey and Reports Section, National Institute of Mental Health, Table B, at 4 (1971)), but in 1967 only $4.2 \%$ of the costs of operating public mental hospitals (C. Taube, Provisional Data on Source of Funds and Expenditures-Mental Fealth Facilities-1967, Statistical Note 5, Biometry Branch, Survey and Reports Section, National Institute of Mental Health, Table B, at $5(1969))$. The state can hardly force the federal government to grant it more money. 
of programs and the impact of costs of one program on the ability of the state to undertake other programs are inevitable and appropriate factors for legislators and other public officials when considering new mental health programs. One unspoken goal of almost every governmental program is to achieve certain social aims at minimum cost. Thus, though the Supreme Court and other courts may ignore, pretend to ignore, or dismiss the significance of financial costs when striking down state practices that in themselves violate the Constitution, ${ }^{380}$ they cannot appropriately disregard such costs when the unconstitutionality of a practice (here involuntary hospitalization) turns on the availability of alternatives that permit the state's goals to continue to be served.

Of course, an obvious danger exists in permitting states openly to rely on higher costs as justification for refusing to initiate programs that would permit the avoidance of involuntary hospitalization. If such a defense is taken to its extreme, a state that placed saving money above every other value might successfully refuse to undertake programs that would permit a twenty per cent reduction in involuntary commitments, even if the net cost of the undertaking was only fifty dollars or even fifty cents per year. On the other hand, not permitting the state to consider costs could lead to compelling it to undertake programs costing millions of dollars each year for a net reduction of a handful of patients in its hospital population. The appropriate balance lies somewhere between these extremes, and the important point is that, as we have seen elsewhere in this article, the principle of the least restrictive alternative is flexible enough to permit a reasonable mean to be acceptable-flexible enough, that is, to permit a court to compel the creation of some alternative programs without forcing it to order the best imaginable community mental health system. ${ }^{\mathbf{3 0 0}}$

389. See, e.g., the Court's decisions ordering the provision of counsel to indigents in felony cases (Gideon v. Wainwright, 372 U.S. 335 (1963)), transcripts to indigents in criminal appeals (Griffin v. Illinois, 351 U.S. 12 (1955)), and invalidating onc-year residency requirements for welfare applicants (Shapiro v. Thompson, 394 U.S. 618 (1969)). In the residency cases, the Court has expressly rejected the state's claims that the high costs of new welfare recipients provide justification for the restriction. 394 U.S. at 633. See also Wyman v. Lopez, 404 U.S. 1055 (1972), and Dunn v. Rivera, 104 U.S. 1054 (1972), affg. mem. Rivera v. Dunn, 329 F. Supp. 554 (D. Conn. 1971).

390. As stated earlier, freedom from confinement having been established as a value with a ruddy constitutional complexion, courts need not permit confinement simply because a state goal will otherwise not be fully served. See pt. V. B. supra. In the context of day-to-day individual commitment decisions, I suggested that for practical reasons a court should be required to place no greater premium on freedom than to 
Even more reassuring to courts entering this territory is that the task of defining the mean between the extremes can in substantial part be left to the states. Facing class actions seeking to force the creation of alternative programs, courts in many states could find that the state had failed to develop adequate community treatment programs on the basis of evidence regarding the efficacy of such programs, the well-established dangers of hospitalization, and the neartotal absence of community-based care for large portions of the state's citizens. The court could then turn to the state and order it either to close its hospitals or to submit a plan to repair the deficiencies in its programs. The court's order would not specify the details of a new program but merely its general scope. To the extent that its order was based on the principle of the least restrictive alternative, the court might direct the state in its plan (1) to make explicit the goals the state is seeking to serve through commitment, (2) to assess in light of those goals the present and future needs of all classes of persons involved in the commitment process, (3) to assay the range of programs that might be instituted to meet those needs, and (4) to reach reasoned conclusions about which programs preserve the maximum level of freedom while serving the state's interests.

The submission demanded may sound more like a presidential commission's report than a response to a judicial decree, but no more would be demanded here than has been required under numerous equitable decrees in the last decade. Consider, for example, decrees in environmental protection cases ordering a public agency to explore the feasibility of less damaging alternatives to a planned public project. $^{301}$ Only if the state refuses to perform part or all of the inquiry or performs it in patent bad faith need a court substitute its own judgment for the state's. ${ }^{302}$

ensure that a person not be hospitalized if there are alternatives that will fully serve the state's purposes. In the context of a broad-gauged class action, however, those practical reasons do not apply: it is different to ask a court once in the context of a class action to attach special weight to the interest in freedom and require the state to spend funds than it is to ask courts that are engaged every day in commitment proceedings to make a determination in each case of the weight that ought to be attached to freedom.

391. See, e.g., Citizens To Preserve Overton Park v. Volpe, 401 U.S. 402, 420 (1971). See also J. SAx, Defending tak Environment: A Strategy for Critzen Agtion (1971), esp. ch. 5, "The Mind-Forged Manacles of Law."

392. Compare the school desegregation and reapportionment cases where the initial burden for devising new plans has almost invariably been left to the state with the federal court imposing a specific remedy only upon stalling, bad faith, or repeated submissions of plainly inadequate plans. Among important decisions dealing with relief 
The enormous complexity and diversity of state interests would require unusual deference on the part of a judge in considering the state's submision. Deference seems especially wise in this area, where so much disagreement persists about the appropriate roles of the various mental health professions in the treatment process ${ }^{303}$ and about the comparative efficacy of various community-treatment approaches. Deference, however, need not be total. Though widely accepted standards for community mental health do not exist, courts can use as benchmarks standards suggested by mental health experts testifying before the court, ${ }^{394}$ expenditures and programs in other jurisdictions, ${ }^{395}$ and standards promulgated by the National Institute of Mental Health and other organizations. ${ }^{306}$

Having suggested several ways in this and the preceding sections for audacious courts to encourage new treatment methods, I nevertheless have little confidence that many courts will respond. However ardently one strives to characterize as modest or traditional the role of courts in a suit to compel a reallocation and expansion of resources for mental health care, the fact remains that most courts will resist entering broad decrees and will search for ways to refer the litigants to the legislature.

Even in suits for individual relief, the unwillingness of courts in this country to confront the warts of the mental health system has been frequently noted. ${ }^{307}$ Moreover, hospital staff and state adminis-

in school desegregation cases, see Green v. County School Bd., 391 U.S. 430, 439 (1968); Swann v. Charlotte-Mecklenburg Bd. of Educ., 402 U.S. 1, 5-10 (1971), on remand, 328 F. Supp. 1346 (W.D.N.C. 1971). For examples of approaches to relief in reapportionment cases, see Scott v. Germano, 381 U.S. 407 (1965); Reynolds v. Sims, 377 U.S. 533, 585.87 (1964).

393. "The number, complexion and variety of the personnel who must collaborate in a [community mental health] center will raise the issue of administrative control, which has for some time plagued the mental health field." Rome, Barriers to the Establishment of a Comprehensive Mental Health Center, in Community Psychiatry, supra note 21, at 53.

394. Compare Wyatt v. Stickney, 325 F. Supp. 781 (M.D. Ala. 1971).

395. For example, Judge Johnson in Wyatt pointed to Alabama's rank as fiftieth among the states in per-patient expenditure per day. $325 \mathrm{~F}$. Supp. at 784. The comparative performances of the fifty states and the District of Columbia in a range of indices of effort in mental health can be found in AMErican Psxchiatric Association, ELEVEN INDICES (1972).

396. The original President's Commission report, Action for Mental Hentth (1961), at xiv recommended, for example, establishing one outpatient clinic for cvery 50,000 persons in the general population. NIMH has developed detailed standards for federally aided community mental health standards. 42 C.F.R. \$ 54.212 (1971). As to the programs of individual centers, its regulations suggest the desirable services to be provided.

397. See Halpern, supra note 370, at 790. Persuading the lower courts and his fellow 
trative personnel are likely to respond to suits with irritation and wounded pride. In right-to-treatment cases, hospital personnel have frequently protested that the complaining patient is in fact receiving treatment; ${ }^{398}$ and they probably could not live with their consciences if they did not believe he was. In the context of a suit based on the principle of the least restrictive alternative, a state mental health commissioner is similarly likely to protest that, given all the demands on the state, he and his department are doing the best that can be expected in order to keep people from being committed unnecessarily. $\mathrm{He}$ is unlikely to feel politically comfortable in submitting to a court a plan that commits the state to new outpatient programs that have not been cleared with the significant members of his legislature-a body that may well be indifferent to the mentally ill and hostile to meddlesome federal district courts. Only a strong judge indeed will be willing to reject the commissioner's best as not good enough and threaten to forbid most involuntary commitments if by a date certain new community-based programs are not in operation.

In the end, perhaps only Congress and the legislatures can assure the development of alternatives to hospitalization. Many states have made encouraging beginnings. But Congress and the President have failed to uphold their side of a bargain the federal government initiated. ${ }^{390}$ Substantially greater development of alternatives may

circuit judges to bring "our problems" out "into the open for confrontation" has become a life's work for Judge Bazelon. See, e.g., United States v. Trantham, 448 F.2d 1036, 1045 (D.C. Cir. 1971) (dissenting from a denial of a petition for rehearing en banc); United States v. Carter, 436 F.2d 200, 211 (D.C. Cir. 1970) (concurring opinion). The frequency with which he has repeated his message bespeaks his lack of success in inducing confrontation.

398. For example, in Rouse v. Cameron, 373 F.2d 451 (D.C. Cir. 1966), the first major right-to-treatment decision, a lengthy hearing was held after remand on the adequacy of care Rouse was receiving. At the hearing, hospital doctors rather angrily asserted that Rouse had been receiving treatment but could point to little other than the hospital's efforts to maintain a therapeutic atmosphere. Since Rouse was shortly thereafter released because of procedural defects in his original commitment, no court opinion is available summarizing the evidence at the hearing. See Rouse v. Cameron, 387 F.2d 241, 242 n.3 (D.C. Cir. 1967).

399. For fiscal 1968, for example, Congress authorized 50 million dollars for constructing community mental health centers, over $20 \%$ less than had been authorized the previous year. Congress then appropriated only 45 million of the 50 million. And the President withheld the entire 45 million. R. Grasscore, J. Sussex, E. Cumming \& L. Smrrf, supra note 296, at 5. On the other hand, for fiscal year 1972, Congress, though appropriating only 15 million dollars for the construction of centers, has raised quite substantially (from 48 million to 90 million to 135 million from 1970 through 1972) the appropriations for community mental health staff. Letter from P. E. Goody, Chief, Budget Management Section, National Institute of Mental Health, April 11, 1972, on file with the Michigan Law Review. Federal funds remain, however, a tiny portion of the nation's mental health care budget. See note 38 supra. 
come into being only if community mental health proves irresistibly cheap, which is possible but unlikely, or if legislators accept the mentally ill as human beings whose self-worth and dignity deserve as much protection as their own. If that realization ever dawns, of course, legislators might put an end to involuntary commitment altogether. The issue of court-compelled use of alternatives would then vanish and with it the need for exhausting articles like this one. 